UNIVERSIDADE DE SÃO PAULO

FACULDADE DE ECONOMIA, ADMINISTRAÇÃO E CONTABILIDADE DEPARTAMENTO DE CONTABILIDADE E ATUÁRIA PROGRAMA DE PÓS-GRADUAÇÃO EM CONTROLADORIA E CONTABILIDADE

O papel dos bancos públicos e dos créditos direcionados na crise financeira de 2008

Catarina Karen dos Santos Silva Orientador: Prof. Dr. Lucas Ayres Barreira de Campos Barros

\author{
SÃO PAULO
}


Prof. Dr. Marco Antônio Zago

Reitor da Universidade de São Paulo

Prof. Dr. Adalberto Américo Fischmann

Diretor da Faculdade de Economia, Administração e Contabilidade

Prof. Dr. Gerlando Augusto Sampaio Franco de Lima

Chefe do Departamento de Contabilidade e Atuária

Prof. Dr. Andson Braga de Aguiar

Coordenador do Programa de Pós-Graduação em Controladoria e Contabilidade 


\section{O PAPEL DOS BANCOS PÚBLICOS E DOS CRÉDITOS DIRECIONADOS NA CRISE FINANCEIRA DE 2008}

Dissertação a apresentar ao Departamento de Contabilidade e Atuária, da Faculdade de Economia, Administração e Contabilidade, da Universidade de São Paulo, como parte dos requisitos para obtenção do título de Mestre em Ciências.

\section{Orientador: Prof. Dr. Lucas Ayres Barreira de Campos Barros}

Versão Corrigida

(versão original disponível na Faculdade de Economia, Administração e Contabilidade)

SÃO PAULO 


\section{FICHA CATALOGRÁFICA}

Elaborada pela Seção de Processamento Técnico do SBD/FEA/USP

\section{Silva, Catarina Karen dos Santos}

O papel dos bancos públicos e dos créditos direcionados na crise financeira de 2008 / Catarina Karen dos Santos Silva. $102 \mathrm{p}$. São Paulo, 2015.

Dissertação (Mestrado) - Universidade de São Paulo, 2015. Orientador: Lucas Ayres Barreira de Campos Barros.

1. Crédito bancário 2. Crédito direcionado 3. Bancos públicos 4. Crise financeira I. Universidade de São Paulo. Faculdade de Economia, Administração e Contabilidade. II. Título. 
À minha família por tudo 



\section{AGRADECIMENTOS}

À minha família, pois todos os dias foram importantes para meu aprendizado e formação do que sou hoje. Ao seu João que nunca me permitiu faltar a uma aula e que sempre soube a importância da educação. À dona Hilda por sempre acreditar nos meus sonhos, apoiar minhas escolhas, por toda dedicação com que me criou e por todo amor. Ao João Luís, parte de mim, pelo seu companheirismo, amizade e amor além da conta, obrigada por me aguentar e ser paciente comigo. E a todos os meus demais familiares.

Ao Professor Lucas Barros por me aceitar como orientanda, por toda ajuda, contribuições, ensinamentos, esforços despendidos, por toda a paciência, sem dúvida merecedor da melhor orientanda do mundo. Você é um exemplo de professor e orientador, tratando sempre os alunos com muito respeito, humildade, além de ter um grande conhecimento e o dom de ensinar. Sempre me lembrarei de você com muito carinho e gratidão.

Aos professores Rafael Schiozer e Leonardo Basso por aceitarem fazer parte da banca e pelas contribuições a esta dissertação.

Aos professores da Faculdade de Economia, Administração e Contabilidade que contribuíram para minha formação ao longo de dois anos intensos, Nelson de Carvalho, Reinaldo Guerreiro, Bruno Salloti, Fernando Múrcia, Gerlando Lima, Isabel Lourenço, novamente ao Lucas Barros, aos professores do departamento de administração, Eduardo Kayo e José Securato, e de economia, Naércio Filho. Agradecimentos também a todos os funcionários da FEA, em especial a Marcia Ferreira.

A todos amigos da minha turma de mestrado e do doutorado com que tive o prazer a cada aula aprender um pouco mais e assim diminuir minha enorme ignorância. Agradeço também ao amigo de doutorado Eduardo Astorino por toda ajuda.

Ao Bruno por todos os dias difíceis estar ao meu lado, pelo apoio, pela dedicação, pela paciência, pelas horas, pelos dias e pelos anos dedicados, pelo amor e carinho. Agradecer ainda é pouco pelo tanto que fez por mim. 
Aos meus amigos de infância que estão em Araçatuba, Jessica, Simone, Silas, Diego e Thiago pelos momentos de muita alegria com que vivemos ao longo de todos esses anos e um agradecimento especial ao Fernando por todo ensinamento e dedicação.

Aos meus amigos da FEA-Ribeirão Preto, Natacha, Danielle, Amanda, Zé, Leandro, Andressa, Mariana, Michel e Igor, por todos os 5 anos bem vividos em Ribeirão e mais um pouco aqui em São Paulo, sejam nas festas da faculdade, na biblioteca ou nas madrugadas estudando paras provas.

Aos meus amigos de Medellín, que compartilharam comigo não somente os ensinamentos da língua espanhola, mas a amizade, o carinho e a gentileza com que me receberam: a Andrés, Marce, Fernan, Carolina e Daniel, e aos meus outros companheiros também trainees Aisec pelo mesmo motivo, Isabel, Alex, Sophia, Matthew e Rebecca.

Aos meus amigos de São Paulo: Márcio, Fernanda, Hudson, Renato, Alex, Carlos, Samantha, Sertório, Ana, Letícia, Bia, Gabi, e meus companheiros de trabalho mais que especiais: Paro, Valter, Antônio, Douglas e Marcus. Ao meu professor de inglês Rodrigo Telles, que além dos ensinamentos foi e é um amigo que me acompanhou nessa trajetória e me ajudou sempre. À Sarah, ao Rudah e a Bianca por toda amizade, conselhos, pela paciência, pela ajuda técnica sempre que precisei. Sem vocês tudo seria mais difícil.

Ao Banco Central do Brasil pela disponibilização dos dados utilizados nesta dissertação, sem os quais não seria possível a investigação. Agradecimento especial a Raquel Oliveira por toda a ajuda técnica e acadêmica e também ao Sérgio Mikio e ao Tony Takeda.

Ao Itaú Unibanco pela oportunidade, falando em pessoas, agradeço ao Carlos André que me incentivou inicialmente a cursar o mestrado, ao Reginaldo Camilo por dar sequência a esta ideia e ao José Tunes pela compreensão da minha ausência, por toda ajuda e ensinamentos ao longo de todo esse tempo. 


\section{RESUMO}

Estudos que avaliam a importância do governo no mercado de crédito têm adquiro mais relevância após a crise econômico-financeira de 2008. Antes os bancos públicos e as políticas de direcionamento do crédito no Brasil eram vistos como ineficientes e até mesmo prejudiciais para o mercado de crédito e consequentemente para a economia. Entretanto, no enfretamento da mais recente crise com impacto global, o governo e seus diversos canais para facilitar o crédito em um cenário de escassez foram percebidos como importantes para manter a estabilidade do crédito. Este trabalho avaliou o papel dos bancos de propriedade pública e da categoria de créditos direcionados para controlar a escassez de crédito durante a crise. A amostra foi composta pelos bancos do Sistema Financeiro Nacional cujas características se enquadraram no objetivo do trabalho, com dados contábeis e financeiros do período entre a crise, de 2005 a 2013. Por meio do uso de dados em painel, o estimador utilizado foi o GMM Sistêmico. Os resultados sugerem que os bancos públicos durante a crise expandiram as operações de crédito, na tentativa de aliviar a contração dos bancos privados. Para a participação do crédito direcionado não foi percebido grandes alterações durante a crise, entretanto como era esperada, a participação dos bancos privados foi mais significativa que a dos bancos públicos nesta categoria de crédito. Também fez parte do estudo observar se os bancos que detinham maior participação de direcionado em sua carteira foram os que mais ofertaram crédito durante a crise, entretanto não foi possível encontrar evidências que apoiasse esta hipótese, e também não se pode concluir que a magnitude foi maior para os bancos de propriedade privada.

Palavras-chave: Crédito bancário, Crédito direcionado, Bancos públicos, Crise financeira. 



\begin{abstract}
Studies assessing the importance of government in the credit market have gained more relevance after the economic/financial crisis in 2008. Before state-owned banks and earmarked policies in Brazil were seen as ineffective and even harmful for the credit market and hence the economy. However, that confronts the latest crisis with global impact, the government and its several ways to promote credit in a scenario of shortage were seen as important to keep credit stability. This study assessed the role of state-owned banks and earmarked credit to control the shortage of credit during the crisis. The sample was compounded by banks in the National Financial System whose characteristics meet the needs of this study, with accounting and financial data for the period within the crisis, from 2005 to 2013. Through the use of panel data, the estimator used was the System GMM. The results suggest that state-owned banks during the crisis expanded credit operations in attempt to relieve the contraction of privately-owned banks. Major changes in the earmarked shares were not noticed during crisis, but as it was expected the privately-owned banks'share was more significant than the state-owned banks'share in this loan category. Additionally, the study aimed to find out if banks that held bigger earmarked share in their portfolio were ones that most offered credit during the crisis, however it was not possible to find evidences that support that hypothesis and also it's not conclusive if the magnitude was higher for privately-owned banks.
\end{abstract}

Keywords: Bank credit, Earmarked credit, State-owned banks, Financial crisis. 



\section{SUMÁRIO}

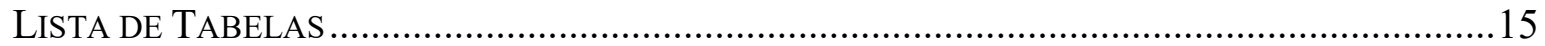

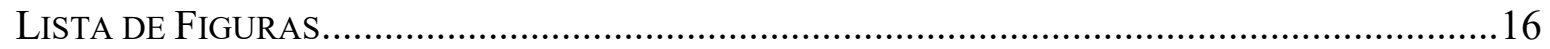

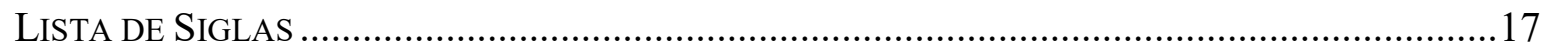

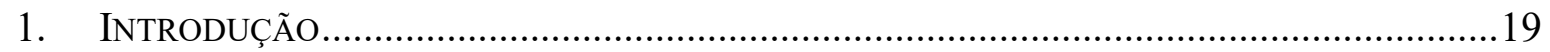

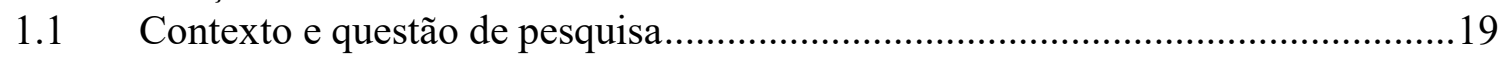

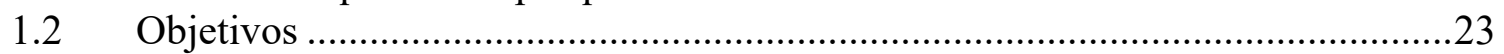

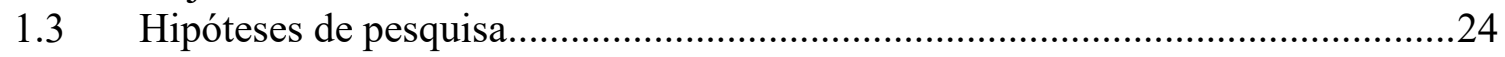

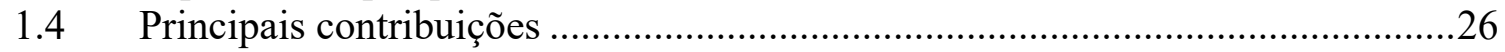

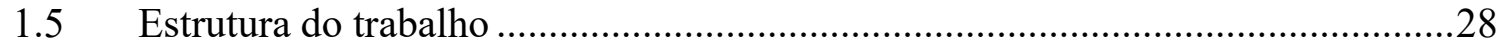

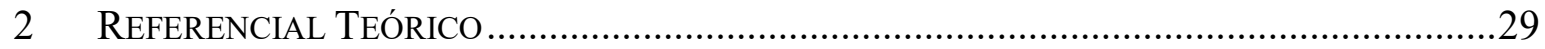

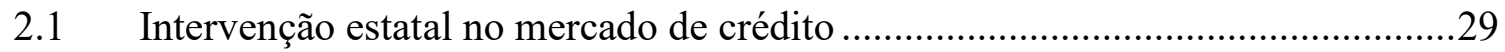

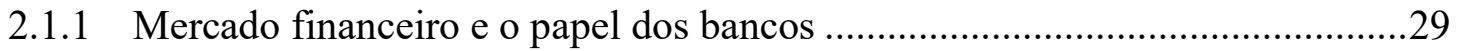

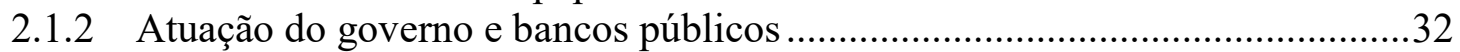

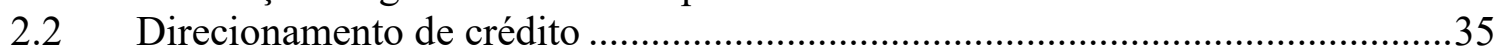

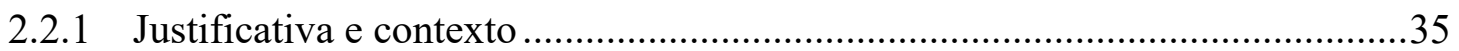

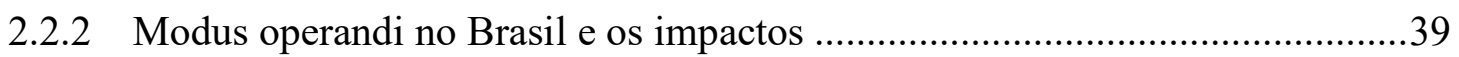

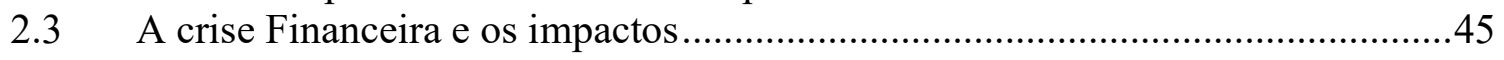

2.3.1 O mercado de crédito e as expectativas dos intermediários financeiros ..........45

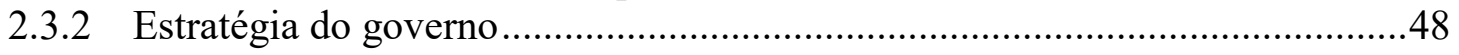

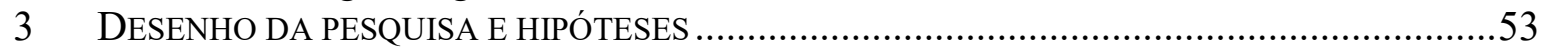

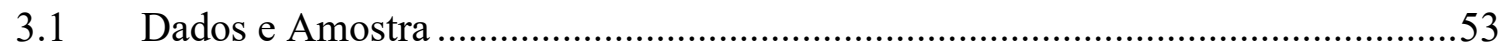

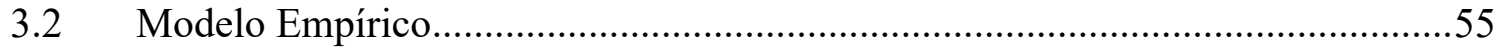

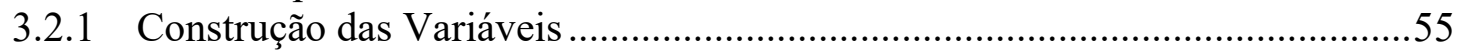

3.2.2 Dados em Painel e Estimação do Modelo Linear ..............................................63

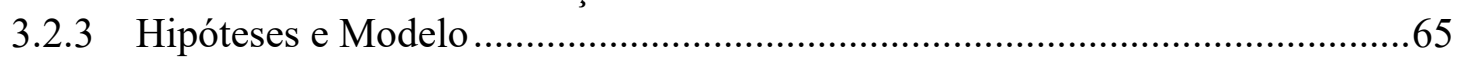

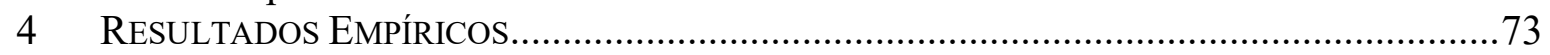

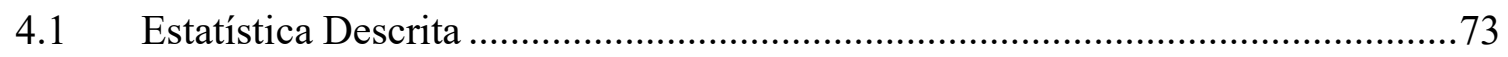

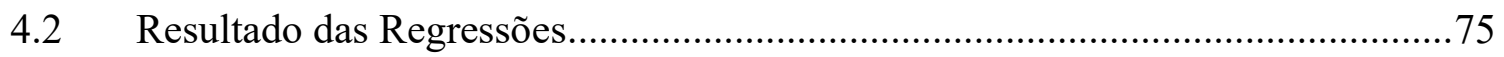

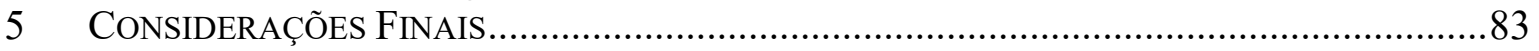

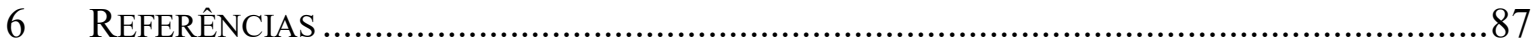

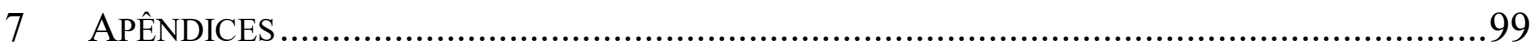




\section{LISTA DE TABELAS}

Tabela 1 - Composição dos créditos por controle em setembro 2008. 55

Tabela 2 - Descrição das Variáveis e efeito esperado de cada hipótese

Tabela 3 - Estatística Descritiva 73

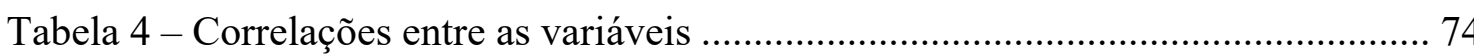

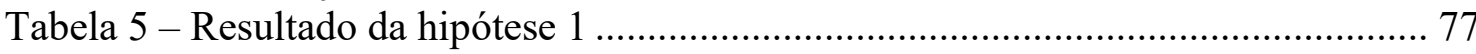

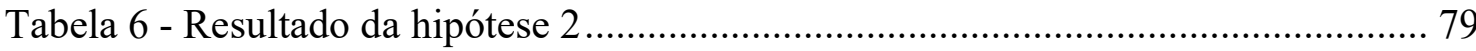

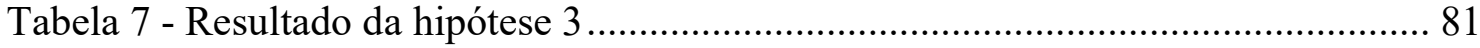

Tabela 8 - Direcionamento de depósito de poupança Rural .......................................... 99

Tabela 9 - Direcionamento de depósito à vista - Crédito Rural .................................... 100

Tabela 10 - Direcionamento de depósito à vista - Microcrédito................................. 101

Tabela 11 - Direcionamento de depósito de poupança................................................. 102 


\section{LiSTA DE FiguraS}

Figura 1. Origem da poupança e participantes da oferta de crédito direcionado........... 41

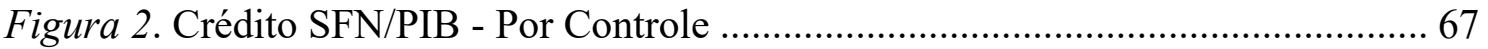

Figura 3. Crédito do SFN/PIB - Livre versus direcionado......................................... 68

Figura 4. Crédito Direcionado do SFN/PIB - Pessoas Físicas e Jurídicas ..................... 72

Figura 5. Recursos Livres e Direcionados por tipo de controle/PIB ........................... 75 


\section{LiSTA DE SIGLAS}

BNDES Banco Nacional de Desenvolvimento Econômico Social

BR GAAP Brazilian Generally Accepted Accounting Principles

CEF Caixa Econômica Federal

CMN Conselho Monetário Nacional

DSGE Modelo Dinâmico Estocástico de Equilíbrio Geral

Fannie Mae National Mortgage, Association

FAT Fundo de Amparo ao Trabalhador

FED Federal Reserve

FFILP Fiscal Investment Loan

FGC Fundo Garantidor de Crédito

FGTS Fundo de Garantia por Tempo de Serviço

FHLBs Federal Home Loan Banks

Freddie Mac Federal Home Loan Mortgage Corporation

GMM Método dos Momentos Generalizados

GMM-Diff GMM em Diferenças

GMM-Sys GMM Sistêmico

IV Variável Instrumental

MCR Manual de Crédito Rural

MQO Mínimos Quadrados Ordinário

PASEP Programa de Formação do Patrimônio do Servidor Público

PIB Produto Interno Bruto

PIS Programa Integração Social

ROA Retorno sobre Ativos

SCR Sistema de Informações de Crédito

SFH Sistema Financeiro da Habitação

SFN Sistema Financeiro Nacional

SNCR Sistema Nacional de Crédito Rural 


\section{INTRODUÇÃo}

\subsection{Contexto e questão de pesquisa}

O desenvolvimento do mercado de crédito permite que os financiamentos aumentem o nível de investimento e consumo de uma economia, assim, está fortemente relacionado com desenvolvimento econômico de um país, sendo sua dinâmica importante para o escopo de políticas públicas.

Os créditos podem ser classificados de acordo com a propriedade e de acordo com a destinação dos recursos, livres ou direcionados, estes se regulados em lei ou normativo, e que por sua vez estes podem ser ofertados tanto por bancos privados quanto públicos.

O direcionamento trata-se de importante mecanismo de alocação de recursos aos setores onde a iniciativa privada voluntariamente não estaria disposta a ofertar, como observa Stiglitz (1993), bons projetos podem ser racionados fora do mercado, pois não são aqueles com maior retorno para o credor. No Brasil os setores favorecidos pelo crédito direcionado são basicamente o rural, imobiliário e microcrédito, além dos recursos de origem do BNDES (Banco Nacional de Desenvolvimento Econômico e Social) que cobrem vastos setores de investimento em empresas de pequeno, médio e grande porte.

O crédito ofertado pelos bancos públicos e aqueles classificados como direcionados evidenciam a participação do governo no mercado de crédito. Embora haja um consenso que políticas públicas possam contribuir para saúde econômica do país/nação, a forma adequada da intervenção estatal ainda divide opiniões de acadêmicos e especialistas no assunto. Os argumentos contrários indicam que o impacto é negativo à medida que alteram as decisões individuais e consequentemente os volumes financiados, provocando resultado "não ótimo" na economia. Já os argumentos a favor sugerem que o mercado possui falhas na alocação e que o governo deve atuar na tentativa de suprir estas falhas.

Contudo argumentos favoráveis à participação mais ativa do governo, seja pela influência na administração dos ativos dos bancos públicos ou pela política de direcionamento do crédito, ganham ainda mais força mediante a crise financeira ou então após seu 
enfrentamento, quando as ações são repensadas como forma de alterar a política vigente. Antes da crise financeira, os bancos públicos eram considerados ineficientes e um fardo para o setor bancário, no entanto após, foram vistos como um fator importante para estabilização do crédito (Allen et al., 2013).

A mais recente crise econômica global, a chamada crise do subprime $^{1}$, favoreceu a deterioração nos balanços dos intermediários, e como consequência o efeito de interromper o fluxo de fundos entre credores e devedores. Este aperto de crédito, por sua vez, pode elevar custo dos empréstimos e, assim aumentar a recessão (Gertler \& Karadi, 2011). Embora os efeitos das crises possam se traduzir em efeitos deletérios, seu enfrentamento oferece oportunidades para melhor compreensão tanto das causas quanto dos meios capazes de minar a expansão e retornar às condições de normalidade.

Pode-se argumentar que a crise do subprime foi um evento exógeno à economia e gerou relevante percepção de risco sistêmico (Oliveira, Schiozer, \& Barros, 2015), o que poderia justificar a retração do crédito pelas instituições financeiras privadas. Essa retração, por sua vez, pode ter sido amenizada pela oferta de crédito público bem como pela oferta de crédito direcionado.

A proposta do trabalho é buscar entendimento sobre o comportamento da oferta de crédito dos bancos de acordo com o controle, público e privado e com a categoria do crédito, livre e direcionado e de que forma as alterações contribuíram para a suavizar a quantidade ofertada no mercado de crédito do Brasil em um cenário de crise global.

\footnotetext{
${ }^{1}$ A crise do credit crunch ou subprime foi caracterizada pelo não cumprimento dos contratos de créditos de alto risco para habitação em meados de 2007. O cenário anterior indicava instabilidade macroeconômica, excesso de poupança global, e as inovações financeiras. Para conhecimento dos motivos que levaram ao "credit crunch" ver Mizen (2008), Taylor, (2009) e Goodhart (2008).
} 
As evidências na literatura internacional e nacional sugerem que durante a crise econômica, o comportamento do crédito sofreu alteração de acordo com a propriedade dos intermediários financeiros. Como suporte, a teoria desenvolvida por Keynes e a abordagem pós-keynesiana sugerem que sob condições de incerteza, a composição do portfólio dos bancos se altera em função das expectativas, demandando aplicações mais líquidas, embora menos lucrativas, ou seja, aumento da preferência pela liquidez ${ }^{2}$ (De Paula, 1999).

Recentes trabalhos que analisaram diversos países do globo concluíram que os bancos privados diminuíram os empréstimos, o que poderia reforçar a teoria de preferência pela liquidez, entretanto para os bancos de controle público as evidências sugerem o contrário, um movimento de expansão da oferta de crédito, possivelmente em resposta à contração privada (e.g., Brei \& Schclarek, 2013, Fungáčová, Herrala, \& Weill, 2013, Allen, Jackowicz \& Kowalewski, 2013 e Brei \& Schclarek, 2015), dado a capacidade que o governo possui em lidar com risco social associado aos distúrbios macroeconômicos. Para o caso brasileiro, alguns estudos também evidenciaram o mesmo comportamento para os bancos públicos e privados (e.g., Annibal, Lundberg, \& Koyama, 2009, Lundberg, 2011 e Pissetti, 2012,).

Os trabalhos citados da literatura internacional tratam de investigação abrangendo vários países. Nestes, não foram consideradas diferenças entre os créditos classificados como livre e direcionado. $\mathrm{O}$ entendimento de cada mercado, considerando as divergências nas políticas de direcionamento de crédito, como a existência, os setores abrangidos e também com relação ao grau de participação do governo, é dispendioso, porém fundamental para as inferências com relação à variação, por exemplo, se a diminuição da quantidade concedida de empréstimo pelos bancos privados foi maior, menor ou em igual proporção

\footnotetext{
2 "As estratégias dos bancos (e tomada de decisões) com relação ao seu portfólio de aplicações considerando sua preferência pela liquidez, como qualquer outro agente cuja atividade seja especulativa e demande algum grau de proteção e cuidado, têm preferência pela liquidez e conformam seu portfólio buscando conciliar lucratividade com sua escala de preferência pela liquidez, que expressa a precaução de uma firma cuja atividade tenha resultados incertos" (De Paula, 1999, p. 21).
} 
para o crédito livre e direcionado. Isto é o que este trabalho se propôs a fazer, porém considerando apenas o caso do mercado brasileiro.

$\mathrm{Na}$ literatura nacional também a maioria dos trabalhos se concentraram na análise do papel da oferta pública de crédito para controlar a liquidez durante a crise, entretanto não analisaram a importância também da oferta de crédito direcionado, seja pública ou privada. Já no trabalho de Bonomo, Brito e Martins (2014), os autores estudaram a intervenção do governo, por meio tantos dos empréstimos concedidos pelos bancos de propriedade estatal e quantos pelos direcionados, porém o foco foi investigar se as empresas beneficiárias são aquelas que enfrentariam inicialmente problema na obtenção de crédito devido a falhas de mercado, projetos não lucrativos e externalidades.

No contexto da realidade complexa e diversificada, este estudo procurará também examinar as particularidades do caso brasileiro, serão consideradas as características das instituições financeiras que a literatura evidencia como mais importantes e capazes de influenciar o crescimento dos empréstimos, além de estudar mais detalhadamente as diferenças na oferta de crédito segundo a natureza das instituições e a classificação do crédito.

A presença da política de crédito direcionado pode ter influenciado a alocação dos financiamentos. Espera-se então que a diminuição no crédito privado se deva principalmente à diminuição na categoria de crédito livre, pois é a parte que os bancos possuem maior autonomia para administrar decisões, uma vez que o direcionado é a parte regulamentada, mesmo embora possam optar por não financiar os setores previstos na regulação do direcionamento de crédito e assim arcar com as penalidades ${ }^{3}$ impostas pelo governo.

${ }^{3}$ Para informação das multas e penalidade, ver tabelas 1, 2, 3 e 4 (anexas). 
Do lado da oferta pública, os bancos podem ter aumentado tanto o crédito livre quanto o direcionado, pois de forma geral o governo teria razões para incentivar ambas as ofertas, dinâmica a ser verificada também neste trabalho.

Em suma, resta entender no contexto de iliquidez provocado pela crise como se deu o comportamento do crédito, se os bancos públicos atuaram de forma a compensar a contração dos bancos privados e se o crédito direcionado teve papel de "colchão" estabilizador, ajudando também na suavização da oferta, pois os bancos optaram por contrair a oferta de crédito livre, aumentando assim a participação do direcionado, bem como a magnitude das alterações, análises ainda pouco exploradas.

A distribuição dos recursos no mercado de crédito é relevante para o entendimento do papel das instituições financeiras e dos mecanismos de direcionamento. Entender as ações adotadas e os incentivos modelam decisões importantes para planejamentos futuros.

O evento de uma crise financeira com dimensões internacionais proporciona ambiente propício para avaliar a contribuição do crédito público e direcionado no mercado de crédito. Portanto, emerge a seguinte questão: os bancos públicos e os mecanismos de direcionamento são importantes para suavizar a oferta de crédito quando há contração da oferta privada e livre?

\subsection{Objetivos}

A fim de responder a questão de pesquisa, este trabalho tem como objetivo verificar de que forma os bancos públicos e a política de direcionamento do crédito afetaram a oferta de crédito durante a crise do subprime. Para isso o trabalho se apoia nos seguintes passos:

I. Identificar as teorias que explicam o comportamento dos intermediários financeiros na concessão de crédito de acordo com o tipo de controle e propriedade.

II. Explorar as particularidades do crédito livre e direcionado, bem como identificar a forma como bancos públicos e privados encaram a alocação, e observar se houve alterações relevantes nas proporções. 
III. Investigar o comportamento do crédito público/direcionado versus privado/livre no entorno da crise.

\subsection{Hipóteses de pesquisa}

Considerando evidências da literatura internacional que o governo desempenhou papel ativo no mercado de crédito, aumentando os financiamentos em resposta à crise do subprime, para o caso brasileiro ambiciona-se verificar se o mesmo ocorreu, acrescentando-se à análise o papel dos créditos direcionados para estabilização da oferta de crédito.

Neste contexto, este trabalho possui as seguintes hipóteses:

Hipótese 1. A propriedade estatal dos bancos se associa positivamente à sua oferta de crédito no período de crise financeira.

$\mathrm{Na}$ perspectiva pós-keynesiana, os bancos constantemente enfrentam o trade-off entre rendimento (lucratividade) e liquidez. As estratégias são adotadas conforme suas percepções de risco e oportunidade de lucro (Caetité, Stranchman, \& Costa, 2009, Paula, 2007 e Fraga, 2009). Se as expectativas são otimistas, a rentabilidade é priorizada em detrimento da liquidez, e no balanço das instituições financeiras é percebido maior oferta de crédito, via empréstimos. Opostamente conclui-se que a preferência pela liquidez será maior em tempos de crise e volatilidade da economia.

Ademais, quando as expectativas são pessimistas e a incerteza elevada, o momento é de cautela na concessão de empréstimos. Porém a manutenção de caixa elevado no balanço aumenta o custo, impactando a margem/rentabilidade e, por conseguinte crescimento limitado e continuidade na redução da oferta de crédito. Nesse ambiente, o governo pode agir interferindo no volume de crédito concedido pelas instituições públicas, com o propósito de impedir que a escassez no mercado dificulte ainda mais a manutenção do nível de produção e emprego da economia. 
A hipótese em questão embora já explorada em diferentes trabalhos acadêmicos para o caso brasileiro, estes não consideraram para a análise variáveis que podem influenciar a decisão de concessão dos empréstimos, como por exemplo a quantidade de depósitos captadas ou o lucro das instituições financeiras.

Hipótese 2. A participação do crédito direcionado na oferta total de crédito dos bancos aumenta no período de crise financeira.

Hipótese 2.1. A magnitude do aumento é maior para os bancos de propriedade privada.

Como os bancos públicos e os privados devem se adequar aos percentuais mínimos de exigibilidades de acordo com sua captação, uma diminuição na oferta de crédito direcionado poderia ser consequência do decréscimo dos depósitos dos bancos. Oliveira, Schiozer e Barros (2015) constataram que no auge da crise, os bancos sistematicamente importantes receberam mais e os bancos pequenos e médios menos depósitos, o que pode ser explicado pela garantia explícita dada aos bancos maiores, embora o aumento da base de depósitos tenha se mantido no Brasil (Annibal, Lundberg \& Koyama, 2009).

Dessa forma, é plausível que a diminuição da concessão de crédito pelos bancos privados tenha sido maior na parte do crédito livre, pois a parte direcionada é regulamentada em normativo, embora os bancos possam optar pelo não cumprimento, arcando com os custos decorrentes.

Se houve diminuição da quantidade ofertada de crédito pelos bancos privados, um possível efeito é o aumento da participação do crédito direcionado, pela razão das proporções, total de direcionados sobre o total de crédito (livres mais direcionados), efeito denominador.

Já para os bancos públicos, a relação de aumento na participação do crédito direcionado não é tão clara. O crescimento da oferta pública (a ser testado na hipótese "1") pode te sido feita através dos créditos livres, e/ou direcionados. Se o movimento dos bancos privados foi de diminuição na oferta do crédito livre, o governo pode ter incentivado os bancos públicos a aumentarem o volume de crédito livre, como forma de compensação, garantindo diversidade no atingimento dos setores, uma vez que o direcionado no Brasil 
é limitado a alguns setores, conforme já explicado. Da mesma forma o crescimento do crédito dos bancos públicos também pode ter sido realizado via recursos direcionados.

A forma como as instituições financeiras públicas se comportaram frente ao crescimento de financiamentos com recursos direcionados ou livres ainda não está clara e também deve ser entendida à luz do comportamento das de origem privada, indicando possíveis tendências de complementaridade das instituições.

Hipótese 3. A participação do crédito direcionado na carteira total de crédito se associa positivamente à oferta de crédito dos bancos no período de crise financeira.

Hipótese 3.1. A magnitude da associação é maior para os bancos de propriedade privada.

O que se pretende investigar é se os bancos com maior participação de direcionado em sua carteira de crédito antes da crise aumentaram mais a oferta total de crédito.

Se o crédito direcionado funciona como um "colchão" estabilizador no mercado de crédito em um contexto de crise financeira, é importante compreender se este fenômeno é guiado pelas instituições financeiras que mais ofertam recursos direcionados, mostrando possíveis tendências. Logo, também será verificado se a sensibilidade da oferta de crédito à participação do direcionado durante a crise é maior para os bancos privados (hipótese “3.1”).

\subsection{Principais contribuições}

A pesquisa atual investiga a forma como os intermediários financeiros reagiram ao choque exógeno e à atuação dos bancos públicos e o mecanismo de direcionamento na estabilização da oferta de crédito durante o período que se traduziu em iliquidez no mercado de crédito após o segundo semestre de 2008.

Há uma larga discussão sobre os efeitos das políticas de intervenção do governo através dos bancos públicos na economia (e.g., Gurley \& Shaw, 1955, Tobin, 1964, Fama, 1980, Stiglitz, 1983 e 1993 e La Porta et al., 2012). O presente trabalho procura colaborar para 
o debate sob a ótica do comportamento do crédito de acordo com a propriedade dos bancos, os mecanismos de direcionamento crédito e seus possíveis impactos.

Além do debate teórico sobre os efeitos, à academia busca-se contribuir com um o modelo de estimação sobre os determinantes do crédito, incluindo a classificação de livres e direcionados e o ambiente macroeconômico (crise de 2008) como fator de influência no mesmo.

No Brasil há pouca literatura sobre o funcionamento e regras do direcionamento de crédito (e.g., Costa \& Lundberg, 2004, Costa \& Nakane, 2005, Torres Filho, 2006 e 2009, Cestare 2007, Cintra 2009 e Lundberg, 2011), e menos ainda sobre o que aconteceu no mercado durante a crise (Annibal, Lundberg \& Koyama, 2009) e o efeito dado a propriedade dos bancos que concedem financiamentos. Desta maneira, mais um ponto que traz originalidade ao trabalho é acrescentar às análises a diferenciação do crédito na categoria livre e direcionado por bancos públicos e privados e considerar as especificidades e as variáveis determinantes do crédito de cada banco, bem como a interação com o ambiente de crise.

A pesquisa também colabora para melhor entendimento do mercado de crédito direcionado, a exemplo de quem são os agentes, os setores beneficiados, as justificativas, a origem da poupança, as regras/obrigatoriedade e os impactos no mercado de crédito e na economia.

Desta forma agrega-se em geral conhecimento ao mercado/sociedade sobre o funcionamento dos mecanismos de direcionamento e sua devida importância, principalmente na crise, como já citado, os estudos para o caso brasileiro carecem de diagnóstico mais detalhado a respeito da interação das características das instituições financeiras, considerando os determinantes do crédito e o controle das instituições financeiras.

Sendo o mercado de crédito importante para o desenvolvimento econômico de um país, tais descobertas contribuem também para o escopo de políticas públicas, sobre a influência das instituições financeiras e as consequências da oferta de crédito aos agentes econômicos e sociedade. 
Por fim, almeja-se que as descobertas sejam relevantes para melhor compreensão do funcionamento do mercado de crédito em diferentes situações, bem como subsidiar discussões a despeito do papel que cada tipo de instituição possui no mercado financeiro e no contexto econômico e social do país.

\subsection{Estrutura do trabalho}

Os próximos capítulos estão estruturados da seguinte forma: no Capítulo 2 há revisão da literatura, e o embasamento teórico. Inicialmente discorre-se sobre a importância do mercado de crédito para a economia, bem como o debate na literatura a respeito da intervenção do governo neste mercado e o papel dos bancos estatais. Em seguida explorase o funcionamento da política de direcionamento de crédito, suas motivações, justificativas e os impactos compreendidos nos trabalhos acadêmicos. Então, por fim, aborda-se o impacto da crise financeira no mercado de crédito e a forma como os bancos reagiram à mesma alterando os volumes de financiamentos e consequentemente como as medidas adotadas governo respondeu às alterações. O capítulo 3 expõe como a pesquisa foi conduzida, para avaliar se os bancos públicos e os créditos direcionados desempenharam papel importante na suavização da oferta de crédito durante o contexto de crise econômica. No capítulo 4 são expostos as estatísticas descritivas e os resultados das regressões, e por fim no capítulo 5 apresentou as principais considerações e contribuições do trabalho. 


\section{REFERENCIAL TEÓRICO}

\subsection{Intervenção estatal no mercado de crédito}

\subsubsection{Mercado financeiro e o papel dos bancos}

Os mercados financeiros envolvem essencialmente a alocação de recursos, incluindo o fluxo inicial de mobilização de recursos para investimentos e posterior seleção dos projetos mais vantajosos a serem financiados, e a construção de mecanismos de monitoramento do desempenho. Stiglitz (1983) considera o mercado financeiro como o "cérebro" de todo o sistema econômico, o lugar central da tomada de decisão, consequentemente uma vez que falharem, não só os lucros do setor serão menores, mas o desempenho de toda a economia pode ser prejudicado.

Logo, são características importantes do mercado financeiro, o gerenciamento intertemporal da liquidez de ativos, as assimetrias de informação do contrato bancário de crédito e a interface da oferta de crédito com investimento na produção de bens das empresas e consumo das famílias.

O Brasil tem o crédito bancário como a principal fonte de financiamento externo às empresas, o conhecido sistema bank-based, assim como o caso de outros países, como o Japão, Alemanha e Itália, contrariamente àqueles cujo financiamento é realizado por instrumentos diretos, ações, títulos de dívida e presença de mercado de crédito bancário de curto prazo, o sistema market-based, caso dos Estados Unidos e Inglaterra (Zyman, 1983).

Porém, como o caso dos países em desenvolvimento, o Brasil possui o sistema financeiro com forte presença de bancos públicos, fato que se apoia no diagnóstico de que a economia apresentava intensas falhas no mercado de capitais e de crédito, contando com a participação direta e intensa do Estado (Schapiro, 2009).

A respeito do papel das instituições financeiras na política monetária, podem-se contrastar duas visões. A primeira é a chamada concepção "clássica" de intermediação financeira, inicialmente desenvolvida por Gurley e Shaw (1955), que prevê que os bancos ao criarem 
moeda estão possibilitando apenas a transferência de recursos dos agentes superavitários aos deficitários, de forma que seu comportamento afete pouco a determinação de condições de financiamento da economia. Opostamente, a segunda, "visão nova", os bancos possuem papel ativo, e suas atividades são guiadas de forma a criarem moedas, de forma dinâmica buscando a maximização do lucro.

Fama (1980) em apoio à visão clássica, afirma que se o sistema bancário é competitivo, os bancos permanecem como intermediários passivos na determinação de preços e das variáveis reais da economia. À medida que estão preocupados com as taxas de administração e não com os tipos de carteiras que gerenciam, as atividades se encaixam no Teorema de Modigliani-Miller ${ }^{4}$ sobre a irrelevância das decisões de financiamento, ou seja, os bancos simplesmente atendem aos gostos e oportunidades dos fornecedores de títulos e os demandantes de depósitos, não possuindo controle da atividade real, como a forma de financiamentos e os preços dos títulos e mercadorias.

No trabalho de James Tobin (1964), o autor classificou a visão "clássica", de que os bancos possuem pouca atuação na determinação de condições de financiamentos na economia, como a "visão antiga" do multiplicador bancário. Em continuidade no trabalho posterior (Tobin, 1987), advogou a favor da "nova visão", onde o uso das reservas bancárias pelos bancos depende tanto das oportunidades de empréstimos quanto das taxas de juros. Por conseguinte, o balanço, com o volume do total de ativos e passivos, seria definido pelo comportamento otimizador do banco, que no equilíbrio competitivo, a taxa de juros cobrada se equipara à taxa de juros paga aos seus credores (De Paula \& Lima, 1999).

\footnotetext{
${ }^{4}$ Ver obra de Modigliani e Miller (1958).
} 
Em linha com a chamada "visão nova", destaca-se a contribuição teórica de John Maynard Keynes e Hyman Minsky a respeito do papel do sistema bancário na determinação das flutuações cíclicas de uma economia monetária. As ideias de Keynes desenvolvidas em “Treatise on Money”, de 1930, partem do contexto histórico de que os bancos, uma vez que têm acesso a reservas adicionais, podem atuar de forma mais agressiva, respondendo de modo dinâmico a um aumento na demanda por crédito dos agentes e expandindo as operações de crédito acima da capacidade determinada pelas reservas do sistema (De Paula \& Lima, 1999).

Na obra de Minsky, "Stabilizing an unstable economy”, de 1986, o autor critica a visão "clássica", reforçando que "In the neoclassical synthesis banking, especially commercial banking, is mechanical, static, and passive; it has no significant impact upon the behavior of the economy" (1986, p. 252) e acrescenta que os empresários dos bancos ao buscarem oportunidades de lucros, ajustam seus ativos e passivos de forma que afetam não somente o volume das finanças, mas também o comportamento cíclico dos preços, salários e do emprego.

É a "visão nova" que orienta a pesquisa da área de Microeconomia Bancária e da moderna Macroeconomia, onde o papel do crédito e dos bancos é relevante para o processo de alocação de recursos da economia (Costa, 2011). Nessa linha, Stiglitz e Greenwald (2003) consideram a demanda e oferta de fundos emprestáveis a chave para entendimento da economia monetária, que consequentemente dependem do papel dos bancos, juntamente com a compreensão e consequências das informações imperfeitas. Para os autores, o sistema de crédito faz parte do equilíbrio geral, o que o torna peça fundamental na determinação da carteira de ativos, taxas de juros, retornos sobre o patrimônio, dos produtos e serviços de mercado e a atividade econômica real.

O desenvolvimento deste trabalho se apoiará no pressuposto que os bancos são agentes ativos, que procuram tirar vantagem das oportunidades de lucros e que afetam a distribuição do crédito e consequentemente os preços, a renda e o emprego da economia (Minsky, 1986). Por conseguinte a premissa de que as instituições financeiras respondem diferentemente a um ambiente de instabilidade considerando suas características específicas e contexto econômico. 


\subsubsection{Atuação do governo e bancos públicos}

A intervenção do Estado na economia divide opiniões, porém, pode-se constatar que nos mais diversos países, incluindo diferentes níveis de desenvolvimento, a presença de medidas advindas do poder central existe em algum grau, seja forte ou fraco, podendo variar de acordo com as condições econômicas.

A teoria econômica neoclássica advoga que a liberalização do mercado permite que o sistema financeiro exerça a função principal de alocar o capital mais eficientemente, de modo a conduzir taxas reais de juros, poupanças agregadas e taxa de crescimento a níveis "ótimos". Logo, a participação do governo na atividade regulatória, como o estabelecimento de preços, quantidades, padrões de qualidade ou metas de investimento, seria um exemplo nocivo à busca do bem comum (Fiani, 1998).

De acordo com essa visão, o Estado não deveria possuir papel ativo nos resultados, indicando que o mercado já se encontra em equilíbrio e completude, as intervenções poderiam alterar as escolhas e ações, indicando a presença de juízo de valor, induzindo preços distintos àqueles praticados livremente, reduzindo a eficiência, além de desperdício dos recursos públicos. O que caberia ao governo seria apenas a correção de falhas no mercado, como agentes com poder de mercado, externalidades no consumo e produção e assimetria de informação.

Alguns estudos empíricos fornecem evidências de que a intervenção não é benéfica para a sociedade como um todo, ao concluírem que maior estabilidade financeira é verificada em países onde o livre mercado é observado comparado aos países cuja presença do governo é mais forte (e.g., Barth, Caprio \& Levine, 2006). Em La Porta, Lopez e Silanes, e Shleifer (2002) os autores encontraram evidências de que a propriedade estatal dos bancos é maior em países com baixa renda per capita, sistemas financeiros pouco desenvolvidos, governos ineficientes e intervencionistas e com pobre proteção aos direitos de propriedade. 
Em contraste com a visão neoclássica, Stiglitz (1983) advoga que o compromisso ideológico simples de liberalização dos mercados financeiros não pode ser baseado na teoria econômica, uma vez as economias com informação imperfeita ou mercados incompletos são, em geral, constrangidas Pareto ${ }^{5}$ eficiente.

No que se refere à participação do governo no mercado bancário, nos trabalhos de La Porta, Lopez de Silanes e Shleifer (2002), Brei e Schclarek, (2013) e Fungáčová e Herrala (2013), os autores contextualizam duas visões sobre a participação do governo no mercado financeiro, a visão "desenvolvimentista" e a visão "política”. A primeira foca no papel do Estado através dos bancos públicos para compensar as falhas de mercado, como por exemplo, externalidades que levam à falta de financiamento a projetos socialmente rentáveis em busca de crescimento econômico. Já na visão "política”, o governo adquire o controle dos bancos com o intuito de proporcionar emprego, subsídios, e outros benefícios que possam se traduzir em favor na forma de votos, contribuições políticas e corrupção, nesta teoria, o governo está disposto a financiar projetos ineficientes, mas politicamente desejáveis.

A visão "desenvolvimentista" está associada ao trabalho de Alexander Gerschenkron (1962), que nota que a propriedade privada comercial dos bancos teve papel principal na canalização de poupança para a fase de industrialização que aconteceu em alguns países na metade do século XIX, entretanto em alguns países, como a Rússia, esses bancos não estavam suficientemente desenvolvidos, por conta da captação incipiente, insegurança da sociedade em manter os fundos, e a incapacidade de financiamento de longo prazo, por isso os bancos estatais cumpriram função primordial para financiar investimentos aos setores importantes para o desenvolvimento das indústrias.

\footnotetext{
${ }^{5}$ Conceito de eficiência de Pareto é quando determinada situação/alocação não pode ser melhorada sem piorar a situação de outro agente, para alcance são condições necessárias: informação perfeita, e irrelevância de custos de transação e flexibilidade perfeita de preços.
} 
Em linha com a participação favorável do Estado no mercado bancário, Stiglitz (1993) ressalta que a existência de falhas e fricções tende a ser mais difundidas no mercado financeiro e existem formas de intervenção do governo que não só fará com que esses mercados funcionem melhor, mas também irá melhorar o desempenho da economia. $\mathrm{O}$ autor cita o exemplo dos países que cresciam rapidamente na Ásia Oriental, onde o governo teve papel ativo na criação de instituições financeiras, na regulação, na direção de crédito, como forma de aumentar a estabilidade da economia e na solvência das instituições financeiras, melhorando perspectivas de crescimento.

A visão alternativa, a "política" da participação do governo é maior em países com sistema financeiro não desenvolvido e pobre proteção aos direitos de propriedade, pois o governo não precisa competir com o setor privado como um recurso de fundos (La Porta et al., 2012), além disso, o controle do governo tende a ser associado às distorções na alocação de recursos, porque os bancos podem ser utilizados por políticos para "amaciar" a restrição orçamentária dos governos (Brei \& Schclarek, 2013).

Para Stiglitz (1993) o governo pode atuar de forma a resolver os problemas de falha no mercado imperfeito, como observa o caso dos países em desenvolvimento, onde as instituições estatais têm sido criadas para preencher as lacunas nos tipos de crédito fornecidos por instituições privadas, em alguns casos, pelas altas taxas de default, ou taxas de juros altas bastante para cobrir os defaults. Sendo as falhas muitas vezes atribuídas à falta de empreendedorismo, de criatividade ou vontade na assunção de riscos, ou também aos retornos privados esperados inferiores aos retornos sociais.

Para corroborar com a visão política, Dinç (2005) ao estudar os principais países emergentes da década de 1990, concluiu que empréstimos de bancos estatais são maiores em anos eleitorais relativos aos bancos privados, indicando que os políticos podem usar os bancos públicos para distribuir rendas aos seus apoiadores.

La Porta et al., (2012) destacam que tanto a visão "desenvolvimentista" quanto a visão "política", o governo financia projetos que não irão ser financiados pelo setor privado, no entanto na teoria do desenvolvimento os projetos são socialmente desejáveis, na teoria 
política não. Em ambas as visões, são prováveis que a função objetivo do Estado inclua a estabilização macroeconômica (Fungáčová \& Herrala, 2013).

Dado que para visão "desenvolvimentista" a propriedade estatal dos bancos ajuda a promover o desenvolvimento financeiro, e a para a visão "política" esses instituições deprimem o desenvolvimento financeiro, como bem observado por Yeyati, Micco e Panizza (2004), o desenvolvimento financeiro e qualidade institucional estão intimamente relacionadas com o crescimento econômico, e para se fazer uma avaliação sobre o papel dos bancos públicos é necessário entendimento da relação causal entre essas variáveis e a propriedade pública, o que ainda permanece como uma questão de difícil ("espinhosa" para os autores) abordagem na economia.

Na literatura de banking predominava até a ocorrência da crise de 2008 a ideia de que o Estado deveria regular menos incisivamente, intervir pouco e atuar em políticas mais específicas às características das empresas e setor, objetivando a concorrência e estabilidade (Costa, 2011). Entretanto com o advento da crise financeira, o cenário começou a mudar, indicando que a participação mais incisiva do governo no mercado financeiro, com o propósito de contornar as perturbações, seria uma alternativa plausível, como por exemplo umas das hipóteses que este trabalho pretendeu avaliar a respeito do papel do governo na política de crédito.

\subsection{Direcionamento de crédito}

\subsubsection{Justificativa e contexto}

O direcionamento de crédito pode ser entendido como instrumento de política para direcionar fluxo de recursos financeiros a setores específicos e com taxas subsidiadas. Conforme já anunciado neste trabalho, La Porta et al., (2012) afirmou que para as visões "desenvolvimentista" e "política", o governo financia projetos que não irão ser providos pelo setor privado, o mesmo argumento prevalece na literatura para justificar a origem do direcionamento. Da mesma maneira encontra-se na literatura argumentos em defesa dos projetos financiados pelo crédito direcionado, sendo socialmente desejáveis, e outros contrários, com custos maiores que os benefícios, sugerindo até mesmo sua extinção. 
Dado a relevância do mercado de crédito, justificam-se os argumentos contrários e a favor. Novamente os apoiadores vão defender que sem esse mecanismo, setores essenciais para a economia não seriam providos de recursos suficientes, haja vista suas características, como alto grau de risco dos projetos associados ao prazo longo de maturidade. A deficiência na alocação pode prejudicar não somente o setor, mas o desenvolvimento da economia, com prejuízo à sociedade.

O contra-argumento é de que o mercado de crédito funciona como um mercado qualquer, onde tanto o credor quanto o mutuário são livres para escolherem pra quem emprestar ou qual banco tomar emprestado, considerando as condições do mercado, taxa de juros, disponibilidade dos agentes (oferta e demanda) e os riscos envolvidos na operação. Como consequência, quem mais valoriza vai receber o que deseja, de modo que o mutuário estará em melhor situação porque está disposto a pagar mais tarde pelo dinheiro agora e o credor estará ganhando o maior lucro possível (Miller, 2010). Essa negociação tende a se realizar, porém em um ambiente livre de falhas de mercado, premissa nem sempre satisfeita.

Já para Stiglitz e Greenwald (2003) os mercados financeiros são muito diferentes de outros e suas falhas tendem a ser mais difundidas. Com informação imperfeita, aqueles que estão dispostos a pagar mais podem não ser aqueles com retorno mais elevado para o credor, o retorno esperado pode realmente diminuir conforme a taxa de juros aumenta, porque a probabilidade de inadimplência pode subir, e como resultado pode haver racionamento de crédito.

Dessa forma, Stiglitz e Greenwald (2003) defendem que parte da justificativa para o crédito direcionado é que bons projetos podem ser racionados no mercado, uma vez que estes apresentam maiores retornos para o credor, pode não ser aqueles com maior retorno total esperado, mas eles são os únicos a serem financiados. Por fim, a intervenção do governo não só fará com que esses mercados funcionem melhor, mas também irá melhorar o desempenho da economia. 
A política de direcionamento de crédito é muito controversa e tem sido alvo de vários debates a respeito da sua efetividade na tentativa de reduzir as ineficiências associadas. Em crítica Vittas e Wang (1991) sugerem que o governo deveria atacar condições que fizeram com que o crédito direcionado parecesse desejável, como as imperfeições no mercado e extrema desigualdade de renda.

Miller (2010) reconhece que a política de direcionamento pode ser politicamente popular e beneficiar os mais pobres, porém desvia os empréstimos para longe de empresas perfeitamente viáveis, formando canais de créditos ineficientes. Assim sendo, o subsídio indireto tem custo que é em grande parte escondido do público.

O programa de direcionamento de crédito é realidade de muitos países, desenvolvidos ou em desenvolvimento, e está relacionado ao grau de participação do governo nas políticas de crédito. O formato do programa que é conduzido em cada país não é uniforme, variando de acordo com a política e diferenciando de acordo com a forma de aplicação, percentuais, taxas de juros, setores beneficiados, a origem da poupança compulsória e as instituições envolvidas, como bancos públicos, privados e desenvolvimento.

Nos Estados Unidos, onde o mercado de capitais é dominante, as captações são realizadas basicamente por instrumentos de garantias aos setores privados (Torres Filho, 2009). Por exemplo, no mercado imobiliário o crédito é ofertado pelas instituições National Mortgage, Association (Fannie Mae), Federal Home Loan Mortgage Corporation, (Freddie Mac) e Federal Home Loan Banks (FHLBs), juntas representam quase metade do crédito para o setor. Os recursos são captados diretamente no mercado, o governo apenas oferece garantia (Torres Filho, 2006).

Com relação à poupança parafiscal, no Japão há um fundo Fiscal Investment Loan (FFILP), semelhante ao FAT (Fundo de Amparo ao Trabalhador), que atua diretamente com o financiamento de grandes projetos, e de pequenas e médias empresas, diretamente ou por meio de instituições públicas de crédito. Novamente, a justificativa para a presença do fundo são investimentos e empréstimos de longo prazo, dos quais seria difícil obter recursos no setor privado (Torres Filho, 2006). 
$\mathrm{Na}$ Índia 40\% dos empréstimos devem ser direcionados aos setores estratégicos da economia, e estes além de incluir setores considerados importantes para a econômica, como agricultura e habitação, incluem também empresas de venture capital, softwares, processamento de alimentos, e habitação de alto custo (Miller, 2010).

Segundo Miller (2010) as decisões de crédito são tomadas fora do reino da maximização do lucro ou de preocupações econômicas e são realizadas no campo da política. O autor conclui que o alto grau de ativos não produtivos e a baixa produtividade do capital para economia indiana nos anos 80 e início dos 90 foi causado pelo crédito direcionado, considerando esta política como uma maneira pobre de alcançar a igualdade.

Ainda no contexto da Índia, Ang (2014) complementa que a política de crédito direcionado retarda a produção de ideias e difusão de novas tecnologias, uma vez que depende de objetivos políticos gerais, além disso, diminui a acumulação de capital e impede a alocação eficiente de recursos.

Costa e Nakane (2005) consolidam algumas ineficiências que surgem em questões específicas a respeito do direcionamento obrigatório de crédito, como por exemplo, (i) o aumento do risco de crédito das carteiras, pois são concedidos em quantidade, taxas e prazos que não atendem aos critérios usuais de escolha, (ii) má focalização, quando os recursos são conduzidos para tomadores que já dispõe de acesso ao mercado de crédito, (iii) problemas de fungibilidade, quando recursos são direcionados a outras finalidades e (iv) problema de principal-agente, quando o cumprimento das exigibilidades é atendido mas por caminhos que não impliquem aplicações efetivas nos setores fim.

Já Odedokun (1996) propõe uma nova alternativa de se estudar o efeito de programas de direcionamento de crédito sobre a eficácia dos empréstimos concedidos pelos bancos de desenvolvimento, não através de determinação da existência ou extensão da substituição entre os repasses e outras formas, mas avaliar os efeitos dos empréstimos bancários ao desenvolvimento (em relação ao PIB) sobre a eficiência do investimento. 
Diante de tais argumentos, pode-se constatar que a política de direcionamento surge em condições de falhas de mercado, ligadas a assimetria de informação, externalidade que faz com que o retorno provado do agente seja percebido como inferior ao retorno social, provocando subprovimento de recursos a determinados setores da economia (Costa \& Nakane 2005). Entretanto a existência do direcionamento pode provocar também mais falhas. A fim de não privilegiar a discussão se a falha é argumento para defender, ou se para abolir a política, o trabalho procurou avançar no entendimento de seu funcionamento, bem como a importância e os impactos, e após, relacionar as informações com a dinâmica da reação na oferta de crédito pelos intermediários financeiros.

\subsubsection{Modus operandi no Brasil e os impactos}

O governo, como instituição responsável pelas políticas públicas, adquiriu ao longo das décadas papel mais atuante no mercado de crédito, procurando manter o bom funcionamento do sistema financeiro, evitando crises bancárias. Entre os mecanismos principais de intervenção do estado neste mercado, pode-se destacar: a regulação prudencial (Regras de Basiléia, órgãos diretivos internacionais), encaixe obrigatório e depósitos compulsórios ${ }^{6}$, FGC (Fundo Garantidor de Crédito) e direcionamento de crédito.

Todas as formas evidenciam a expressiva participação do governo no mercado financeiro na tentativa não somente de corrigir falhas de mercado, como externalidades e assimetrias de informação, mas também manter o controle macroeconômico, de estabilidade no produto, consumo e cumprimento da política monetária.

6 BACEN (2014) “Atualmente, no Brasil, existem as seguintes modalidades de recolhimentos compulsórios e de encaixe obrigatório: Recolhimento compulsório sobre recursos à vista; Recolhimento compulsório sobre recursos de depósitos e de garantias realizadas; Encaixe obrigatório sobre recursos de depósitos de poupança; Recolhimento compulsório sobre recursos a prazo; e Exigibilidade adicional sobre depósito". 
O direcionamento de crédito, diferentemente da política prudencial e da monetária, não foca o mercado como um todo, mas afeta as condições taxas de juros, prazos dos empréstimos, bem como setores, regiões ou categorias de empresas (Torres Filho, 2009).

No Brasil, a política de direcionamento obrigatório de crédito é regida por normatizações específicas do Conselho Monetário Nacional (CMN), que através do BACEN (Banco Central do Brasil) torna públicas as resoluções que as instituições financeiras devem atender. Tais regras dizem respeito (i) ao percentual mínimo obrigatório que os bancos devem aplicar sobre o saldo dos recursos captados, (ii) aos setores considerados estratégicos e (iii) às taxas de juros a serem cobradas no financiamento.

Com as altas taxas de juros para padrões internacionais, a oferta de crédito de longo prazo é realizada majoritariamente pelos créditos direcionados (Lundberg, 2011). A insuficiência de mercado do crédito de longo prazo é interpretada pelas autoridades econômicas como uma falha de mercado, desta maneira, as medidas intervencionistas, como os mecanismos de poupança compulsória e o direcionamento de crédito priorizam os objetivos macroeconômicos em detrimento da eficiência microeconômica (De Freitas, 2007).

Os bancos públicos são os principais ofertantes do crédito direcionado, tendo à frente os agentes financiadores: Caixa Econômica Federal (CEF), no âmbito do Sistema Financeiro da Habitação (SFH), Banco do Brasil (BB) na esfera do Sistema Nacional de Crédito Rural (SNCR), e o BNDES por meio das operações de repasse direto para financiamento de investimentos nas empresas. O direcionamento de crédito também cobre outros setores, como por exemplo, o microcrédito destinado à população de baixa renda e a microempreendedores ${ }^{7}$, porém com participações modestas.

\footnotetext{
${ }^{7}$ Ver Medida Provisória No 122, de 25 de Junho de 2003 e a Resolução No 4.153 de 30 de outubro de 2012.
} 
Aproximadamente 43\% das operações de crédito em 2013 sofreram algum tipo de direcionamento, de acordo com o sistema de séries temporais do BACEN (2014d). De forma genérica, presume-se que se o governo escolhe manter e aprofundar a política de direcionamento de crédito é porque espera que os benefícios sociais sejam maiores do que a ineficiência econômica gerada pela intervenção (trade-off entre equidade e eficiência) ou por outros interesses, como políticos por exemplo.

A poupança para financiamentos dos setores/empresas ou famílias tem origem em recursos de natureza fiscal (bancos públicos e BNDES), que embora por mecanismo voluntário, é sujeito à determinação do governo a depender das políticas de incentivo ou retração, ou do mercado, estes podem ser divididos em compulsórios (bancos públicos e privados) e voluntários (bancos públicos, privados e BNDES), note na Figura 1.

\section{Poupanca $\quad \underline{\text { Mecanismo }} \quad \underline{\text { Participantes }}$}

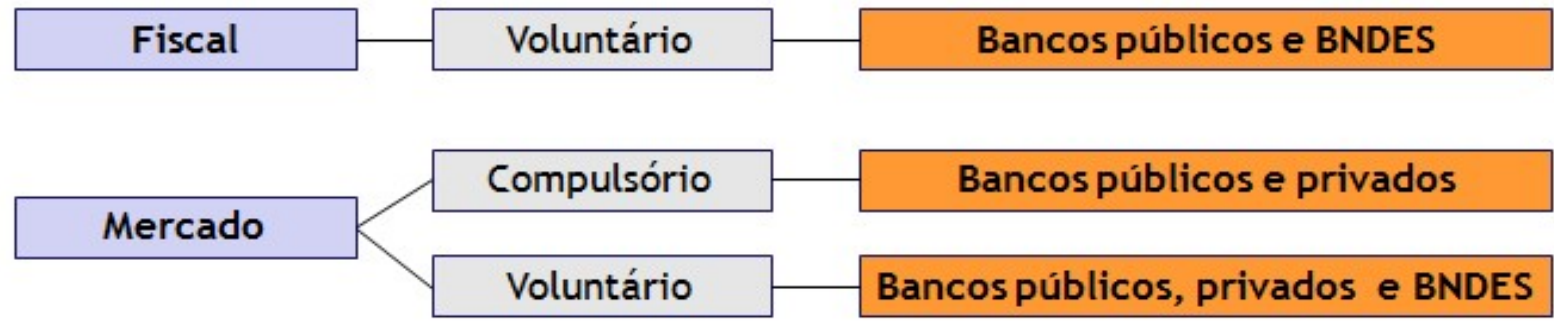

Figura 1. Origem da poupança e participantes da oferta de crédito direcionado Fonte: Autoria própria

Os recursos fiscais são oriundos da arrecadação dos impostos por meio da vinculação de percentuais e os de natureza parafiscal oriundos da cobrança de taxas. Os dois principais fundos parafiscais são o FGTS (Fundo de Garantia por Tempo de Serviço) e o FAT, além de cumprirem o papel de seguro social (benefícios aos trabalhadores), contribuem também para financiar investimentos sociais via intermediação dos bancos, BNDES, CEF 
e outras instituições oficiais ${ }^{8}$ (Pinheiro, 1997), sendo o FGTS administrado pela CEF e destinado a financiamento imobiliário e saneamento urbano, e o FAT pelo BNDES e possui destinação para investimento em máquinas e equipamentos industriais e em infraestrutura econômica (Cintra, 2009).

Nos mecanismos compulsórios o governo determina que instituições públicas ou privadas direcionem um percentual mínimo dos recursos captados (poupança, depósito) a determinados setores, com condições de prazo e taxas estabelecidas, caso não haja cumprimento das condições há a imposição de penalizações (deficiências). Em 2004 os recolhimentos obrigatórios, após o recolhimento do compulsório, segundo o BACEN (2014e) eram:

- os depósitos decorrentes de insuficiência no direcionamento para operações de financiamento imobiliário dos recursos captados em depósitos de poupança;

- insuficiência no direcionamento dos recursos captados em depósitos à vista para operações de crédito destinadas à população de baixa renda e a microempreendedores; e

- o decorrente da insuficiência no direcionamento para crédito rural.

Dessa forma, constata-se que os setores beneficiados com a poupança compulsória são: imobiliário ( $65 \%$ dos depósitos de poupança), microcrédito e baixa renda ( $2 \%$ dos depósitos à vista) e rural (13\% dos depósitos à vista, sendo 34\% a partir de 01/07/2016 e $67 \%$ dos depósitos de poupança rural), conforme Tabelas anexas 8, 9, 10 e 11 .

Nos voluntários, o governo atrai os recursos por meio de garantias públicas, como o seguro de crédito, ou, em menor medida, por meio de equalização de taxas de juros, onde

\footnotetext{
${ }^{8} \mathrm{O}$ risco da operação é por conta do governo, sem prejuízo aos trabalhadores.
} 
o governo se compromete a pagar parte da taxa de juros que seria devida pelo tomador final, ou para reduzir o ônus dos juros ou tornar fixa uma taxa variável (Torres Filho, 2006), alterando o risco, custo ou o prazo das operações finais (Torres Filho, 2009).

Outra forma de participação dos bancos no direcionamento de crédito é através dos repasses indiretos do BNDES. Nesta opção, os bancos públicos, privados, agências de fomento e cooperativas credenciadas pelo BNDES fazem a análise do crédito, e decidem pela aprovação considerando as garantias envolvidas e os riscos, que é todo assumido pela instituição financeira, embora para operações com pequenas e médias empresas pode ser garantido pelo BNDES FGI - Fundo Garantidor para Investimentos (BNDES, 2014). Nota-se que os recursos são do BNDES, cuja poupança ${ }^{9}$ pode ser diversa, incluindo fundos FGTS, FAT, PIS/PASEP (Programa Integração Social/Programa de Formação do Patrimônio do Servidor Público), recursos do Tesouro Nacional, aplicações e outras.

Qual seria então o estímulo que os bancos teriam para atuar como agentes "repassadores" dos créditos de origem do BNDES, e assumindo o risco da operação? Os incentivos para concessão são o pagamento da taxa de intermediação financeira e a remuneração ${ }^{10}$, além de vantagens como melhor relacionamento e fidelização da carteira de cliente (BNDES, 2014b).

Como consequência, as decisões sobre o volume do crédito direcionado impactam as decisões alocativas dos intermediários financeiros, provocando o enfrentamento do tradeoff entre eficiência e cumprimento das diretrizes. Ao se implementar a exigibilidade, os

\footnotetext{
${ }^{9}$ Para discussão a respeito das fontes do BNDES, ver Prochni \& Machado (2008).

10 “Taxa de Intermediação Financeira é a taxa que reflete o risco sistêmico das Instituições Financeiras Credenciadas, limitada a 0,5\% ao ano. As operações com Micro, Pequenas e Médias Empresas, operações na Linha Apoio às Exportações - Pré-embarque Empresa-Âncora e na Linha Modernização da Administração Tributária e Gestão dos Serviços Sociais Básicos - BNDES PMAT estão isentas da taxa de intermediação financeira. Nas operações na Linha Leasing de Bens de Capital incide Taxa de Intermediação Financeira independentemente do porte da empresa arrendadora ou arrendatária. Remuneração da Instituição Financeira Credenciada é a taxa que reflete o risco de crédito assumido pelas Instituições Financeiras Credenciadas, e será determinada pela instituição repassadora dos recursos" (BNDES, 2014b).
} 
intermediários financeiros passarão a considerá-las nas decisões, o que será refletido no volume e taxas de juros cobradas do crédito livre (Costa \& Lundberg, 2004).

Há um amplo debate na literatura sobre os efeitos do direcionamento de crédito. Argumenta-se que as taxas subsidiadas desta modalidade pressionam a taxa livre de mercado, ou seja, os bancos prejudicados pela obrigação de "baixar" a taxa do crédito direcionado a patamares menores do que seria praticado no mercado livremente, estariam repassando os prejuízos para o crédito livre. Logo a imposição de condições no mercado de crédito implica em custos fiscais ocultos, criando distorções (Filipinas Llanto, Geron \& Tang 1999), e consequentemente alguns agentes estariam em pior situação.

Cestare (2007) avaliou o impacto das políticas de direcionamento de crédito, juntamente com a política de compulsório, sobre o volume de crédito ofertado e sobre a taxa de juros praticada no mercado de crédito livre e conclui que aumento no parâmetro destas políticas implica spreads mais altos cobrando pelos bancos (em comparação ao caso destas políticas não forem utilizadas), como forma de compensar taxas menores de remuneração recebidas sobre a aplicação em depósitos compulsórios e créditos direcionados.

Segundo Costa e Nakane (2005) em 2001 o subsídio cruzado, que aparece quando a normatização determina que a oferta de crédito direcionado seja feita por taxas subsidiadas menores do que as observadas no mercado, respondeu por 7,57\% do spread nas operações com crédito livre, dos quais 5,02\% são devidos às operações obrigatórias do crédito imobiliário e 2,55\% ao crédito rural.

Torres Filho (2006) argumenta que nos estudos sobre o efeito do direcionamento de crédito sob as taxas de juros do crédito livre não devem estar inclusos os bancos públicos, uma vez que estas instituições são por sua natureza mecanismo de direcionamento de crédito, além disso, ressalta que os bancos privados possuem participação reduzida na carteira, $8,5 \%$ em 2005.

Conforme observou Cintra (2009) e Torres Filho (2006) na literatura no Brasil advoga-se a extinção das operações direcionadas (eg., Costa \& Lundberg, 2004, Costa \& Nakane, 
2005 e Arida, 2005), porém não explicam quais seriam as consequências. Cintra mais incisivo critica a forma como os autores desconsideram as causas que levaram o Brasil a adotar o mecanismo de direcionamento do crédito:

Esses autores parecem desconsiderar as razões que levaram o Estado brasileiro a "bancar" o crédito de longo prazo e a inabilidade do sistema financeiro nacional para alongar prazos mesmo em contextos de relativa estabilidade da economia (como no período de 1966-1973 e 2004-2007). Parecem sugerir que o alongamento dos prazos seria uma tendência natural em um sistema financeiro desregulamentado e orientado pelo mercado. A despeito das modificações estruturais ocorridas nos mercados financeiros privados a partir dos anos 1980, criando novos instrumentos de crédito, o papel do Estado continua relevante na mobilização de recursos a serem canalizados para setores e atividades de elevado retorno social, seja em âmbito doméstico, seja em âmbito internacional Cintra (2009, p. 97).

Torre Filho (2006) ressalta que há a ideia daqueles que advogam pelo fim do direcionamento obrigatório de wishfulthinking, que é a fé em algo que se deseja que seja verdade, deva ser abandonada, uma vez que em um cenário que as taxas de juros estão caindo e a integração externa aumentando, qualquer movimento brusco pode comprometer o crescimento econômico. O que se sugere é reforma gradual nos mecanismos de direcionamento e acompanhado de evolução no mercado.

\subsection{A crise Financeira e os impactos}

\subsubsection{O mercado de crédito e as expectativas dos intermediários financeiros}

O mercado de crédito age como facilitador da atividade econômica, determinando os gastos dos assalariados, dos empreendimentos, e, por conseguinte da distribuição da riqueza. Desse modo, impacta também o nível do emprego, a taxa de investimento e a trajetória da economia. Embora a importância em estudar este mercado seja de entendimento geral, cabe ressaltar a dificuldade envolvida, Stiglitz e Greenwald (2003) 
apoiam a impossibilidade de encaixá-lo no modelo de equilíbrio geral ${ }^{11}$, visto que o crédito pode ser criado com quase nenhuma entrada de fatores convencionais, e pode ser facilmente destruído, por fim, não há maneira fácil de representar a função de oferta de crédito.

As características do crédito comportam que os intermediários financeiros façam o monitoramento do contrato, estimando a probabilidade do cumprimento, considerando os riscos envolvidos. Destarte, a informação necessária para decisões de modelagem da oferta de crédito vai depender não somente das características de cada instituição e família, mas do cenário econômico envolvido.

A crise financeira tem fortes implicações no mercado de crédito, os agentes percebem as condições econômicas deterioradas, neste cenário há avanço de incertezas e pessimismo. As empresas não financeiras e famílias (tomadores de empréstimos/mutuários) diminuem a contratação de crédito e as instituições financeiras também contraem os financiamentos. Esse aumento de preferência por liquidez trata-se de uma medida conservadora, que busca fortalecimento das condições caso haja um revés no mercado, entretanto pode implicar na interrupção das atividades, piorando o cenário econômico.

A estabilidade do banco e a dinâmica do crédito estão relacionadas aos problemas de financiamentos, tanto interno quanto externo. $\mathrm{Na}$ recessão, os bancos diminuem os empréstimos na tentativa de evitar a escassez de liquidez, e podem alimentar crescimento em bons tempos para melhorar o financiamento interno em épocas de instabilidade. No entanto, se o financiamento interno nas crises é insensível à expansão do crédito anterior,

\footnotetext{
${ }^{11}$ Complementando às justificativas dos autores: "The reason for this is simple: credit is based on information. Ascertaining that an individual is credit worthy requires resources; and standing by that judgment, providing or guaranteeing credit entails risk bearing. There is no simple relationship between these economic costs and the amount of credit extended" (p.16).
} 
na recessão os empréstimos se tornarão tóxicos, levando os bancos a falharem (Bucher \& Hauck, 2013).

Gertler e Kiyotaki (2010) constataram que no ambiente de crise, a ausência de fricções traz como consequência recessão moderada, entretanto com fricções, especialmente no mercado interbancário, a ruptura endógena da intermediação financeira contribuir para ampliar a crise.

Do lado dos tomadores, outro pode ser o agravante para a contração dos empréstimos, a elevação do spread de crédito. No contexto da crise, Gertler e Kiyotaki (2010) descreve a dinâmica da situação em que os balanços dos mutuários uma vez deteriorados, possivelmente associados à deterioração nos preços dos ativos, faz com que o prêmio de financiamento externo aumente, ou seja, há um impacto sobre o custo de crédito e em seguida compressão da atividade real, evidenciando um feedback entre o setor financeiro e os setores reais da economia.

Ainda reforçando a mudança no comportamento dos agentes não financeiros, Nguyen e Qian (2013) ressaltam que as empresas enfrentam dois problemas, a oferta de crédito e a demanda por fatores, bens e serviços. Do lado do crédito, um choque negativo pode significar para as empresas diminuição do capital de giro e paralisação da produção, e para a demanda, um choque adverso se traduz em declínio de consumidores dos produtos e serviços. Ao estudar as empresas do leste europeu, os autores encontraram evidência de que para a grande maioria, a mudança da demanda é o principal efeito da crise, indicando como a principal causa para a melhoria ou agravamento dos negócios. Entretanto como os próprios autores ressalvam, o declínio da demanda pode ser atribuído ao problema de crédito, ou também à diminuição da riqueza ou crescimento da incerteza.

A despeito da forma de transmissão da crise, Perri e Quadrini (2010) constataram que choques no mercado de crédito são mais relevantes que choques na produtividade, especialmente na dimensão global. Uma vez que os países são financeiramente integrados, os movimentos no mercado de crédito geram grande propagação para setores reais e financeiros dos outros países. 
A contração na oferta de crédito pressiona os spreads de taxa de juros, elevando mais a diminuição na concessão de empréstimos, conforme observou Ivashina e Scharfstein (2010), a combinação de recessão e crise bancária é particularmente problemática. Entretanto as flutuações no mercado de crédito são altamente assimétricas, ou seja, as contrações são mais nítidas do que as expansões, provocando no equilíbrio, declínio nos preços dos ativos, do emprego e da atividade econômica (Perri \& Quadrini, 2011).

Geralli et al. (2010) ao estudar o papel da oferta de crédito em ciclos econômicos, através de um modelo de equilíbrio geral dinâmico com fricções financeiras e setor bancário imperfeitamente competitivo, concluíram que as flutuações geradas pelo setor bancário explicam a maior parte da contração da atividade econômica em 2008, enquanto choques macroeconômicos desempenharam papel mais limitado.

Logo, com a eminência de piora no cenário, reforçada pela escassez do crédito privado, governos e bancos centrais de todo o mundo foram incentivados a buscarem políticas que envolvem a prestação de liquidez, entre elas, a liberação de crédito pelos bancos estatais.

\subsubsection{Estratégia do governo}

Segundo Junior e Teixeira Filho (2009), a dimensão dos prejuízos não foi o mais importante fato no cenário econômico internacional no segundo semestre de 2007, mas a ameaça à saúde financeira de importantes bancos e fundos de investimento.

Antes do início recente crise econômica de 2008, Micco e Panizza (2006) analisaram uma série de países industrializados e em desenvolvimento para testar se a propriedade dos bancos públicos contra os privados, nacional e estrangeiro, está correlacionada com o comportamento do crédito nos ciclos-econômicos, as evidências foram de que os estatais podem exercer função anticíclica, visto que, para contrapor a contração na oferta de crédito de instituições privadas, além de se evidenciar que a oferta de recursos de bancos públicos é menos sensível a choques macroeconômicos.

A adoção de política monetária mais participativa na época de "anormalidade" não se constituiu fenômeno exclusivo do Brasil, muitos outros países o fizeram. Brei e Schclarek 
(2013), no estudo com 50 países distribuídos nas regiões da Europa Avançada e Emergente, América Latina e Caribenha, encontraram evidências da maior presença dos bancos públicos via concessão de crédito em tempos de crise, sugerindo que o Estado pode desempenhar papel anticíclico nos seus sistemas bancários.

Allen et al. (2013) ao examinar a amostra de países da Europa Central e Oriental, encontraram evidências de que os bancos de propriedade estrangeira e estatal reagem diferentemente a uma crise nacional e mundial, os bancos estrangeiros ofertaram mais crédito durante episódio de crise doméstica, dada a independência interna e dependência externa, e diminuíram na recente crise global de 2008 em contraste com o aumento dos bancos estatais, ressaltando que um setor bancário misto é aconselhável.

Gertler e Karadi (2011) através do desenvolvimento de um modelo DSGE (Modelo Dinâmico Estocástico de Equilíbrio Geral) avaliaram os efeitos da política monetária de expansão do crédito bancário do banco central, que não enfrentam constrangimentos em seu índice de alavancagem, para combater uma crise financeira. Os resultados sugerem que nessa época, as restrições de balanços dos bancos privados "apertam", aumentando os benefícios líquidos da intermediação do banco central ${ }^{12}$.

Fungáčová, Herrala e Weill, (2013) também investigaram a influência da propriedade dos bancos na oferta de crédito durante a recente crise para o caso da Rússia. Ao aplicar a metodologia de fronteira estocástica, os autores concluíram que a redução dos financiamentos foi maior para os bancos de propriedade estrangeira e menor para os controlados pelo Estado em comparação aos bancos privados nacionais.

\footnotetext{
12 Entretanto os autores (Gertler \& Karadi, 2011) observam que certos tipos de empréstimos, por exemplo, ativos securitizados de alta qualidade, tais como títulos lastreados em hipotecas, os custos de intermediação do banco central podem ser relativamente baixos. Neste caso, a intermediação direta do banco central pode ser justificada. Em outros casos, por exemplo em empréstimos que requerem monitoramento constante dos mutuários, a intermediação do banco central pode ser altamente ineficiente, neste caso injeções de capital são preferidas.
} 
Após o colapso do sistema bancário, seguido da falência do Lehman Brothers, o FED (Federal Reserve) começou a emprestar diretamente nos mercados de crédito de alto grau na tentativa de reanimar o mercado. Desde agosto de 2007 a quantidade de ativos emprestados aumentou cerca de 800 bilhões para mais de dois trilhões de dólares, grande parte do aumento vindo após o colapso do Lehman (Gertler \& Peter Karadi, 2011). Destaca-se que para a atuação durante a crise, o banco central tem a vantagem de facilmente obter recursos através da emissão de dívida pública de curto prazo, diferentemente dos bancos privados, que são limitados pela fraqueza de seus balanços (Gertler, Kiyotaki \& Queralto, 2012).

Já a atuação do governo brasileiro também foi reforçada para combater os efeitos da crise global, em evidência o Globo (2013) destaca que a equipe econômica brasileira não somente usou os bancos públicos para garantir a oferta de crédito, mas também reduziu os juros e abriu mão de quase 188 bilhões de reais em tributos ao longo de 2008 a 2013 para estimular a economia. Em outubro de 2008, o BACEN adotou a estratégia de liberação de parte do recolhimento compulsório sobre os depósitos a fim de suprir as necessidades de bancos menores (Dawid \& Takeda, 2011).

Além disso, o BACEN juntamente com CMN adotou uma série de medidas de gestão de liquidez, especialmente quando se intensificou a segmentação entre instituições de pequeno e grande porte. As iniciativas contemplaram além do depósito compulsório, as operações com o FGC e redesconto que contribuíram para remover a constrição de liquidez (Mesquita \& Torós, 2010).

O governo tem vantagens quando se refere à assunção de risco. Stiglitz (1993) enumera: primeiro, pode obrigar a participação dos membros em programas de seguro e consequentemente evitar os problemas de seleção adversa que assolam mercados de risco, segundo a capacidade de mitigar os efeitos de risco moral que surgem porque os credores não dispõem de informações e terceiro é a vantagem que os mercados privados não conseguem lidar com o problema de risco moral associados aos distúrbios macroeconômicos. 
Por ora apresentou-se a forma como as instituições financeiras são vistas dentro do contexto de desenvolvimento da economia, bem como sua importância e papel. Com o evento crise, essas instituições reagiram diferentemente à oferta de crédito de acordo com o controle. Fará parte do escopo deste trabalho investigar: (1) se os bancos privados reterem liquidez e consequentemente os bancos públicos reagiram na tentativa de compensarem a contração aumentando os empréstimos, (2) se a oferta de crédito direcionado se mostrou como mecanismo importante de suavização do crédito e de que forma este evento está associado também à propriedade dos bancos e (3) se os bancos que mais ofertaram crédito direcionado no período pré-crise foram os que mais contribuíram para o crescimento do crédito durante a crise. 


\section{DESENHO DA PESQUISA E HIPÓTESES}

\subsection{Dados e Amostra}

Parte dos dados contábeis das instituições financeiras foram extraídos do sítio do Banco Central do Brasil (BACEN, 2014c), no relatório "50 maiores bancos e o sistema consolidado do Sistema Financeiro Nacional"13. Já as informações sobre concessão de crédito classificadas como livres ou direcionados foram extraídas do Sistema de Informações de Crédito (SCR), base de dados confidencial do Banco Central do Brasil ${ }^{14}$.

As informações financeiras são de frequência trimestral dos bancos comercias, de investimentos, múltiplos e caixas econômicas que compõem o Sistema Financeiro Nacional (SFN) do período de 2005 a 2013. O escopo do trabalho constitui os bancos com carteira comercial, os bancos de desenvolvimentos foram excluídos da amostra, por possuírem objetivos diferentes aos demais bancos com relação aos setores beneficiados, taxas e origem de captação.

O BNDES embora importante ofertante do crédito direcionado, como pode ser visto na Figura 4, como os demais bancos de desenvolvimento não está contido na amostra. Além dos argumentos expostos acima, destaca-se que todo crédito ofertado por ele é classificado na categoria de direcionado, definindo lógica de funcionamento diferente em comparação aos demais bancos.

Por fim, dado a delimitação desta pesquisa, sugere-se para os próximos estudos a investigação do papel dos bancos de desenvolvimento na crise. Cabe ressaltar a dificuldade envolvida nos dados do BNDES ao não separar os créditos (todos na categoria

\footnotetext{
${ }^{13}$ Para maiores detalhes de quais são as instituições financeiras que fazem parte da base, ver site do BACEN (2014) "50 maiores bancos e o consolidado do Sistema Financeiro Nacional”.

${ }^{14} \mathrm{~A}$ extração dos dados foi conduzida exclusivamente por staff do Banco Central do Brasil.
} 
direcionado) em repasses indiretos (recursos do BNDES), ou seja, nos dados direcionados de cada banco incluem eventuais repasses, dessa forma os financiamentos estão classificados tanto no balanço do BNDES quanto no balanço do banco tomador. Portanto nota-se que o volume de crédito direcionado inclui um componente compulsório (percentuais dos depósitos à vista e poupança) e outro voluntário (repasses do BNDES e garantias do governo).

As instituições financeiras compostas na amostra tratam-se de conglomerados ou independentes (caso a instituição não faça parte de nenhum conglomerado), ou seja, alguns bancos apresentaram a visão consolidada do "Conglomerado" (resultado das operações e a situação econômica, patrimonial e financeiro do grupo de empresas) e outros, a visão do individual "Instituições Independentes".

Os bancos que não apresentaram operações de crédito ou captação de depósitos foram excluídos da amostra, uma vez que o objetivo deste trabalho é analisar o mercado bancário de crédito e aqueles bancos que captam funding do mercado para compor a concessão de crédito.

Com o intuito de evitar baixa representatividade na amostra, dentre os bancos que apresentaram operações de crédito somente foram considerados aqueles com representatividade igual ou maior que $1 \%$ das operações de crédito em relação ao total de ativo e quando analisado a participação dos créditos direcionados foram retirados os bancos que não concederam empréstimo classificado nesta categoria. Também foram retirados os bancos que sofreram intervenção do BACEN por motivo de fraude contábil ${ }^{15}$.

\footnotetext{
${ }^{15}$ Banco BVA, intervenção em 2012, indícios de fraudes contábeis, desvio de recursos, gestão temerária e elisão fiscal entre os anos de 2007 e 2012. Banco Rural, liquidado em 2013, fraude ao violar normas e regulamentos das atividades bancárias sobre a classificação de riscos, entre 2003 e 2005. Banco Cruzeiro do Sul, intervenção em 2012, criação falsa de operações de créditos sem conhecimento cujo recursos eram distribuídos a determinadas empresas de "fachada" e aplicados para elevar o valor das ações e remuneração dos
} 
As aquisições e fusões foram tratadas como se as instituições formadas após o evento fossem uma nova empresa. Um período antes da incorporação foi criada uma terceira empresa virtual que soma todas as variáveis da empresa incorporada e da incorporadora (Oliveira, Schiozer \& Barros, 2015), desta forma no momento da incorporação a terceira empresa possui dados do período anterior para compor a variável de crescimento do período atual de forma a representar o real crescimento do banco. ${ }^{16}$

Na tabela 1 pode ser visto um recorte de setembro de 2008, início da crise no Brasil, pela composição dos créditos concedidos de acordo com o controle dos bancos, o número nesse período foi de 100 bancos, ao longo dos anos de 2005 e 2013 totalizou-se 141 bancos, a diferença se refere aos bancos que entraram ou saíram do SFN.

Tabela 1 - Composição dos créditos por controle em setembro 2008

(R \$ Milhões)

\begin{tabular}{lcccc}
\hline & Número de bancos & Recuros direcionados & Recursos livres & Total de empréstimos \\
\hline Controle Público & 12 & 119.100 & 293.790 & 412.889 \\
Controle Nacional & 53 & 52.660 & 369.130 & 421.790 \\
Controle Estrangeiro & 35 & 41.359 & 232.990 & 274.350 \\
Total & $\mathbf{1 0 0}$ & $\mathbf{2 1 3 . 1 1 9}$ & $\mathbf{8 9 5 . 9 1 0}$ & $\mathbf{1 . 1 0 9 . 0 2 9}$ \\
\hline
\end{tabular}

\subsection{Modelo Empírico}

\subsubsection{Construção das Variáveis}

O total dos empréstimos refere-se ao saldo das operações de empréstimo, financiamento

e arrendamento mercantil, concedidas pelas instituições. Em essência, o BACEN

controladores, no período de 2007 a 2012. Banco Panamericano, intervenção em 2010, irregularidades contábeis desde 2006, balanço inflado por meio de registros de carteiras de crédito vendidas.

${ }^{16}$ Por exemplo um período anterior a empresa $\mathrm{X}$ com ativos de 100 incorpora a empresa $\mathrm{Y}$ com ativos de 50 e é criada a empresa $\mathrm{Z}$ (virtual) que soma os dados da empresa X e Y, ou seja, 150 de ativos. No período da incorporação a empresa $Z$ tem os dados do período anterior para compor a variável de crescimento, porém os dados do período anterior não comporão a regressão, uma vez que não possui dados anteriores. 
considera transações de leasing como operações de crédito, portanto a divulgação acontece pelo saldo consolidado. Este total se refere à soma dos créditos classificados como livre e direcionados.

A categoria dos créditos livres implica em empréstimos cujas instituições financeiras não são obrigadas a atender setores específicos e condições de taxas de juros. Já o montante de crédito direcionado, opostamente, é a parcela dos créditos concedidos que sofreram algum tipo de direcionamento, seja pela distribuição da quantidade arrecadada de depósito à vista ou poupança, pela quantidade repassada dos recursos advindos do BNDES (repasse indireto), ou pela ação voluntária das intuições bancárias em conceder empréstimos que atendam as condições impostas.

Outra limitação do trabalho é assumir que a crise financeira modificou apenas as expectativas dos bancos e consequentemente as decisões sobre as quantidades concedidas de empréstimos. Entretanto com relação às expectativas dos demais agentes econômicos, seja pessoa física ou jurídica, não se pode concluir que não houve alteração de preferências, um declínio demanda poderia estar relacionado com a queda na concessão de empréstimos durante a crise.

Nos trabalhos empíricos o período de crise diverge dependendo do aspecto considerado, setor comercial e financeiro ou do país analisado, ainda há controvérsias sobre período de início e fim da crise no Brasil. Embora a crise nos países epicentros tenha começado a dar sinais já em 2006, as evidências sugerem que o impacto no mercado brasileiro foi posteriormente.

Em dezembro de 2007 o crescimento do PIB foi de 6,2\% e o nível de desemprego aumentou 9\%, em 2008 o PIB foi de 5,2\% e o desemprego de $16 \%$ e em 2009 com PIB de $0,3 \%$ e o desemprego se manteve, porém em 2010 estes indicadores já começaram a apresentar sinais de melhora, com crescimento do PIB de 7,5\% e desemprego $11 \%$, segundo dados do IBGE (Instituto Brasileiro de Geografia e Estatística) e IPEA (Instituto de Pesquisa Econômica Aplicada). 
O período de crise considerado no presente trabalho foi a partir de setembro de 2008, (De Freitas, 2009) até final de 2009, ano conhecido como o final do período crítico global.

A classificação das propriedades de controle ${ }^{17}$ foi seguida segundo a classificação do $\operatorname{BACEN}(2014, d)$ :

- Sistema financeiro público: operações realizadas por instituições financeiras em que a União e os governos estaduais detêm a maioria do capital votante, de forma direta ou indireta;

- Sistema financeiro privado nacional: operações realizadas por instituições financeiras em que pessoas físicas e/ou jurídicas domiciliadas e residentes no País detêm a maioria do capital votante; e

- Sistema financeiro estrangeiro: operações realizadas por instituições financeiras que tenham sob controle estrangeiro, direta ou indiretamente, a maioria do capital votante, assim como as instituições constituídas e sediadas no exterior com dependência ou filial no País.

Dentro da classificação de banco público se enquadram as instituições de controle federal e estadual, e para banco privado aqueles de origem nacional, e estrangeiro. A classificação dos bancos domésticos e estrangeiros dentro da categoria "privado" não trouxe prejuízos aos resultados, uma vez que as evidências sugerem que os bancos estrangeiros contraíram mais a oferta de crédito durante a crise do que os bancos privados nacionais.

Oliveira, Schiozer e Leão (2012) observam que para os bancos estrangeiros a concessão de crédito livre foi afetada mais intensamente e por um período maior do que os bancos

${ }^{17}$ Controle de capital: com relação à ótica do controle de capital das instituições financeiras, segundo a definição da Carta-Circular 2.345, de 25.1.1993 
privados nacionais, situação que se inverte somente a partir do $3^{\circ}$ trimestre de 2010 até o final de 2011.

A forma funcional genérica dos modelos a serem estimados neste trabalho pode ser representada como: a variável dependente em função da variável dependente defasada (painel dinâmico), dummies de crise Cri, e propriedade dos bancos Gov (público) e Pri (privado), a interação entre estas dummies, o vetor " $B$ " das variáveis de controle, e o erro $v_{i, t}$, composto pelo fator não observável constante no tempo, $c_{i}$ (efeito específico do banco) e outro fator não observável que varia ao longo do tempo, $\varepsilon_{i, t}$.

$$
Y_{i, t}=\beta_{0}+\beta_{1} Y_{i, t-1}+\beta_{2} \operatorname{Cri}_{t}+\beta_{3} \text { Gov }_{\text {Pri }_{i, t}}+\beta_{4} B_{i, t}+\beta_{5} d t+v_{i, t}
$$

Onde $i=1, \ldots, N$ e $t=1, \ldots, T, \quad v_{i, t}=c_{i}+\varepsilon_{i, t}$ e $E\left[v_{i, t}\right]=0$.

Nos modelos construídos para verificar as hipóteses do trabalho encontram-se o $t$ representado pelos trimestres de 2005 a 2013 e $i$ as instituições bancárias. A variável dependente ora é o crescimento dos empréstimos ( $\Delta E$ - diferença entre o logaritmo dos empréstimos $t-1$ e logaritmo dos empréstimos no tempo $t$-2) e ora a participação do crédito direcionado $(P D$ - valor dos empréstimos direcionados sobre o total dos empréstimos). As variáveis de interesse são as dummies de propriedade do banco (Gov para propriedade estatal valor 1 e privada valor 0 e Pri para propriedade privada valor 1 e pública valor 0), de crise (Cri - no período do segundo semestre de 2008 ao último trimestre de 2009) e a interação entre as mesmas (CrixGov e CrixPri).

As variáveis de controle estão representadas no vetor "B", sendo estas as principais características de cada instituição bancária utilizada em trabalhos empíricos, entre os quais pode-se destacar os trabalhos de Fucidji e Mendonça (2006), Allen, Jackowicz e Kowalewski (2013) e Brei e Schclarek (2013), para explicar a variação no volume dos empréstimos. As variáveis de controle a serem utilizadas no trabalho são: crescimento 
dos depósitos $(\triangle D e p)$, a liquidez $(L)$, a capitalização $(C a)$, tamanho da instituição $(L N A)$, e a rentabilidade $(R)$, apresentados na equação:

$$
B_{i, t}=f\left(\Delta D e p_{i, t}, L_{i, t}, C a_{i, t}, L N A_{i, t}, R_{i, t}\right)
$$

A variável de depósitos $(\Delta D e p)$ será representada pela variável de crescimento dos depósitos ${ }^{18}$ (diferença entre o logaritmo dos depósitos à vista em $t$ e logaritmo dos depósitos à vista em $t$-1). Espera-se que o crescimento dos depósitos esteja positivamente correlacionado com o crescimento da oferta de crédito, embora os bancos sejam capazes de criar crédito independentemente da existência prévia de depósitos em consonância com a teoria pós-keynesiana.

A visão de Minsky (1986) detalha a instituição financeira como agente dinâmico que atua nos dois lados do balanço, desenvolvendo técnicas de administração do passivo (liability managment), onde os depósitos deixam de ser exógeno, e os intermediários passam a influenciar as preferências por depósitos. Dessa forma, a variável de "depósitos" pode estar correlacionada com as características dos bancos.

A liquidez ( $L$ ) é medida pela participação do total de ativos líquidos (Disponibilidades, Aplicações Interfinanceiras, Títulos e Valores Mobiliários e Instrumentos Financeiros Derivativos, Relações Interfinanceiras, Relações Interdependências) dividido pelo ativo total. Também é esperado coeficiente positivo, pois quanto mais líquido for o banco maior seria sua disposição em conceder empréstimos. Porém, em épocas de crise, o coeficiente pode ser ambíguo, "as liquid banks could shy away selling assets in a extremely risky environment and decide to hold these liquid assets until the turmoil calms down and market prices recover" (Brei e Schclarek, 2013, p.5).

${ }^{18}$ Os depósitos são referentes aos depósitos à vista, a prazo, interfinanceiros, poupança e outros. 
A capitalização $(\mathrm{Ca}$ ) representa a relação entre o patrimônio líquido e o total do ativo, e avalia se o capital próprio da instituição é suficiente para uma margem de segurança financeira. Dietrich e Wanzenried (2011) observam que bancos mais bem capitalizados são mais rentáveis e permanecem rentáveis durante a crise. Também é esperado que quanto maior a capitalização mais recursos disponíveis para aumentar os empréstimos durante a crise (Brei e Schclarek, 2010).

O tamanho do banco é medido pelo logaritmo dos ativos totais $(L N A)^{19}$. Bancos maiores, beneficiados pela economia de escala, têm mais produtos e diversificação de empréstimos que bancos menores. Kishan e Opiela (2000) constatam que os bancos menores (valor dos ativos) e menos capitalizados são mais responsivos à política contracionista, indicando que são incapazes de levantar alternativas de fundos para continuar com financiamento de crédito. Entretanto para Brei e Schclarek (2013) o efeito é ambíguo, uma vez que bancos pequenos tendem a prover mais empréstimos.

A rentabilidade (ROA), retorno sobre ativos (Return on Assets) é uma das principais medidas de rentabilidade usada em trabalhos acadêmicos, é definida como o valor do lucro líquido sobre o total de ativos, refletindo a habilidade do banco em gerar lucros a partir dos seus ativos. A expectativa é que a rentabilidade tenha coeficiente positivo, quanto mais lucrativo mais resistente será a choques adversos e, portanto, maior a possibilidade de conceder empréstimos.

As variáveis características das instituições financeiras são informações encontradas nas demonstrações financeiras dos agentes bancários. Assim sendo, como será tratado apenas o caso brasileiro, tem-se vantagem na comparação de informações das empresas, leiamse bancos, por tratar-se da mesma prática contábil, o BR GAAP (BR - Brazilian, GAAPs

19 A "logaritimização" desta variável se refere ao processo de transformação Box-Cox, usado para enfrentar problemas de heterocedasticidade e/ou falta de normalidade (Aguirre, 1997). 
- Generally Accepted Accounting Principles), pois a adoção de padrões diferentes poderia implicar em valores de apuração divergentes nas demonstrações contábeis o que pode prejudicar as inferências. Na tabela 2 encontra-se a descrição de todas as variáveis por hipótese e os efeitos esperados.

Nos modelos estimados também foram incluídas as dummies de tempo para controlar o efeito agregado da economia sobre as variáveis. Na tabela 2 há a relação das variáveis, com a descrição e o efeito esperado. 
Tabela 2 - Descrição das Variáveis e efeito esperado de cada hipótese

\begin{tabular}{|c|c|c|}
\hline Variáveis - Hipótese 1 & Descrição & Efeito esperado \\
\hline \multicolumn{3}{|l|}{ Dependente } \\
\hline$\Delta$ Empréstimos & Crescimento do total dos empréstimos ((-) $\log _{t}$ e $\left.\log _{\mathrm{t}-1}\right)$ & \\
\hline \multicolumn{3}{|l|}{ Interesses } \\
\hline Crise & Valor 1 de setembro/2008 a dezembro/2009 e 0 caso contrário & - \\
\hline Governo & Valor 1 para controle estatal e 0 caso contrário & - \\
\hline GovernoXCrise & Interação entre dummy de Governo e Crise & + \\
\hline \multicolumn{3}{|l|}{ Controles } \\
\hline$\Delta$ Empréstimost-1 & Crescimento do total dos empréstimos $\left((-) \log _{t} \mathrm{e} \log _{t-1}\right)$ defasado & $+/-$ \\
\hline$\Delta$ Depósitos & Crescimento do total dos depósitos $\left((-) \log _{\mathrm{t}} \mathrm{e} \log _{\mathrm{t}-1}\right)$ & + \\
\hline Liquidez & Ativo Líquido dividido pelo Ativo Total & $+/-$ \\
\hline Capitalização & Patrimônio Líquido dividido pelo Ativo Total & + \\
\hline Tamanho & Log dos Ativos Totais & $+/-$ \\
\hline ROA & Lucro Líquido dividido pelo Ativo Total & + \\
\hline Variáve is - Hipótese 2 & Descrição & Efeito esperado \\
\hline \multicolumn{3}{|l|}{ Dependente } \\
\hline \multicolumn{3}{|l|}{ Participação Direcionado } \\
\hline \multicolumn{3}{|l|}{ Interesses } \\
\hline Crise & Valor 1 de setembro/2008 a dezembro/2009 e 0 caso contrário & $+/-$ \\
\hline Privado & Valor 1 para controle privado e 0 caso contrário & - \\
\hline PrivadoXCrise & Interação entre Parcipação Direcionado defasada, dummy de Privado e Crise & + \\
\hline \multicolumn{3}{|l|}{ Controles } \\
\hline Participação Direcionado $t-1$ & Divisão do total de direcionados pelo total de crédito (livres+direcionados) defasada & $+/-$ \\
\hline$\Delta$ Depósitos & Crescimento do total dos depósitos $\left((-) \log _{\mathrm{t}}\right.$ e $\left.\log _{\mathrm{t}-1}\right)$ & + \\
\hline Liquidez & Ativo Líquido dividido pelo Ativo Total & $+/-$ \\
\hline Capitalização & Patrimônio Líquido dividido pelo Ativo Total & + \\
\hline Tamanho & Log dos Ativos Totais & $+/-$ \\
\hline ROA & Lucro Líquido dividido pelo Ativo Total & + \\
\hline Variáveis - Hipótese 3 & Descrição & Efeito esperado \\
\hline \multicolumn{3}{|l|}{ Dependente } \\
\hline$\Delta$ Empréstimos & Crescimento do total dos empréstimos ((-) $\log _{t}$ e $\left.\log _{t-1}\right)$ & \\
\hline \multicolumn{3}{|l|}{ Interesses } \\
\hline Crise & Valor 1 de setembro/2008 a dezembro/2009 e 0 caso contrário & $+/-$ \\
\hline Privado & Valor 1 para controle privado e 0 caso contrário & - \\
\hline PrivadoXCrise & Interação entre dummy de Privado e Crise & - \\
\hline Participação Direcionado ${ }_{t-1} \mathrm{XCrise}$ & Interação entre Parcipação Direcionado defasada e Crise & $+/-$ \\
\hline Participação Direcionado ${ }_{t-1} X P$ rivadoXCrise & Interação entre Parcipação Direcionado defasada, dummmy de Privado e Crise & + \\
\hline Participação Direcionado ${ }_{t-1} X P$ rivado & Interação entre Parcipação Direcionado defasada e dummy de Privado & + \\
\hline \multicolumn{3}{|l|}{ Controles } \\
\hline$\Delta$ Empréstimos $\mathrm{t}-1$ & Crescimento do total dos empréstimos ((-) $\left.\log _{\mathrm{t}} \mathrm{e} \log _{\mathrm{t}-1}\right)$ defasado & $+/-$ \\
\hline Participação Direcionado $t-1$ & Divisão do total de direcionados pelo total de crédito (livres+direcionados) defasada & $+/-$ \\
\hline$\Delta$ Depósitos & Crescimento do total dos depósitos $\left((-) \log _{\mathrm{t}}\right.$ e $\left.\log _{\mathrm{t}-1}\right)$ & + \\
\hline Liquidez & Ativo Líquido dividido pelo Ativo Total & $+/-$ \\
\hline Capitalização & Patrimônio Líquido dividido pelo Ativo Total & + \\
\hline Tamanho & Log dos Ativos Totais & $+/-$ \\
\hline ROA & Lucro Líquido dividido pelo Ativo Total & + \\
\hline
\end{tabular}




\subsubsection{Dados em Painel e Estimação do Modelo Linear}

Os dados da pesquisa caracterizam-se como dados em painel, ou seja, a análise de informações de vários bancos do SFN variando ao longo do tempo. Uma das vantagens do uso de painéis é o conjunto de observações obtidas com a multiplicação do número de indivíduos com o número de períodos de tempo, formando-se dados suficientemente grandes para aplicar técnicas econométricas.

O pressuposto para que o modelo (1) seja estimado de forma consistente é o termo erro $v_{i, t}$ seja não correlacionado com todos os regressores, caso contrário as variáveis regressoras são denominadas de endógenas e os resultados serão inconsistentes. A causa da endogeneidade pode ser diversa, como por exemplos erro de medida, simultaneidade e variável omitida. A condição para que os estimadores sejam não viesados variam dependendo dos estimadores, para análise dos dados em painel os mais comuns são o MQO (Mínimos Quadrados Ordinário), estimador de primeira diferença, efeito fixo e efeito aleatório.

A equação (1) pode ter forma simplificada com intuito de melhor exemplificar as condições para os estimadores, imagine:

$$
Y_{i, t}=\phi X_{i, t}+v_{i, t}
$$

O pressuposto fundamental para que a estimação por MQO nos modelos de dados em painel produza coeficientes consistentes é de que o termo erro não seja correlacionado com todos os regressores no tempo presente $t$. Uma condição suficiente para isto é:

$$
E\left[v_{i, t}, \mid x_{i, t}, c_{i}\right]=0
$$

Sendo $E[. \mid$. ], o operador de esperança condicionada. Entretanto para a estimação pelos métodos de 'efeitos fixos' e de 'efeitos aleatórios', a condição é a suposição de "exogeneidade estrita", condição bem mais restritiva do que MQO, representada por:

$$
\begin{aligned}
& E\left[v_{i, t}, \mid x_{i, 1}, x_{i, 2}, \ldots, x_{i, T}, c_{i}\right]=0 \\
& E\left[\varepsilon_{i, t}, \mid x_{i, 1}, x_{i, 2}, \ldots, x_{i, T}, c_{i}\right]=0
\end{aligned}
$$


Sendo que a condição (5) se aplica ao estimador de 'efeitos aleatórios' e a condição (6) ao estimador de 'efeitos fixos'. A "exogeneidade estrita" implica impossibilidade de qualquer correlação de entre erro atual $(t)$ e os regressores de qualquer tempo $(t-T, \ldots, t-1$, $t, t+1, \ldots t+T)$. Uma alternativa para uso dos estimadores que exigem a "exogeneidade estrita" é o uso de variáveis instrumentais, entretanto nem sempre é fácil encontrar esse tipo de variável nos estudos de finanças.

A escolha entre os estimadores de primeira diferença, efeito fixo e efeito aleatório se baseia na independência do termo $c_{i}$, caso este seja independente de todas as variáveis explicativas, em todos os períodos de tempo, a escolha do efeito aleatório é preferível, pois dada esta condição este estimador é mais eficiente. Entretanto se houver qualquer razão para acreditar que $c_{i}$ esteja correlacionado com quaisquer regressores e tempo, o efeito fixo é preferível, uma vez que este estimador assim como o estimador de primeira diferença utiliza transformação para eliminar o efeito não observado de $c_{i}$.

O modelo geral estimado neste trabalho, explicitado na equação (1) inclui a variável dependente defasada. A justificativa é que além capturar persistência temporal na série, ajuda a controlar o problema de variável omitida. Entretanto ao tentar resolver este problema outro é acrescido, por construção este modelo não atende a suposição de "exogeneidade estrita" exigida nos modelos de efeito fixo, efeito aleatório e primeira diferença. Como alternativa para resultados consistentes mesmo na hipótese de endogeneidade advindas do uso do painel dinâmico os estimadores mais utilizados em trabalhos acadêmicos são o Estimador de Variável Instrumental (IV - Instrumental Variable) e o Método dos Momentos Generalizados (GMM - Generalized Method of Moments).

Neste trabalho o estimador escolhido, dado suas propriedades frente ao modelo e dados disponíveis, foi o $G M M$, pois permite o uso da variável dependente defasada, efeito específico dos bancos correlacionado com os regressores e dummies de tempo. Destacase a habilidade deste estimador em trabalhar com (1) variáveis independentes não estritamente exógenas, (2) pela presença do efeito fixo correlacionado com os regressores, 
(3) painel de períodos de tempo pequenos $(T)$ e observações individuais grandes $(N),(4)$ heterocedasticidade e autocorrelação (Roodman, 2006).

Dados as propriedades do GMM, neste trabalho será utilizado o estimador GMM proposto por Blundell e Bond (1998) com a variante one-step e o teste de Hansen para verificar a validade dos instrumentos.

\subsubsection{Hipóteses e Modelo}

Para a hipótese 1, o intuito é verificar se aqueles bancos estatais aumentaram a quantidade de empréstimos durante a crise, controlando possíveis impactos negativos no mercado financeiro como resposta a contração da oferta privada.

A contração do volume de crédito concedido pelos bancos privados pode ser percebida conforme figura 2, após o período do segundo semestre de 2008 praticamente não houve crescimento, em contraste maior crescimento para os bancos públicos.

Neste primeiro momento ainda não há a separação do que representa o crédito livre e direcionado, o foco está na propriedade dos bancos e sua função durante a crise. Para se testar a hipótese, o modelo a ser utilizado apresenta a variável dependente defasada como variável explicativa (painel dinâmico). A relação entre as variáveis pode ser resumida na equação:

$\Delta E_{i, t}=\alpha_{0} \Delta E_{i, t-1}+\left(\alpha_{1}+\alpha_{2} \operatorname{Cri}_{t}\right)+\left(\alpha_{G 1}+\alpha_{G 2} \operatorname{Cri}_{t}\right) G o v_{i, t}+\alpha_{3} B_{i, t}+\alpha_{4} d t_{t}+c_{i}+\varepsilon_{i, t}(7)$

onde,

$\Delta E_{i, t}=$ é a taxa de crescimento do total dos empréstimos bancários (diferença entre o logaritmo dos empréstimos $t$ e logaritmo dos empréstimos no tempo $t-1$ ) do banco $i$.

$\Delta E_{i, t-1}=$ é a taxa de crescimento do total dos empréstimos bancários (diferença entre o logaritmo dos empréstimos $t$ - 1 e logaritmo dos empréstimos no tempo $t$-2) do banco $i$. 
$C r i_{t}=$ é a variável dummy para o período de setembro de 2008 a dezembro de 2009.

$G_{i t}=$ é a variável dummy para controle estatal, assume valor um para os bancos de origem pública e zero para os demais, no tempo t.

$\operatorname{Cri}_{t} \operatorname{Gov}_{i t}=$ é a interação (multiplicação) da variável dummy de crise com a dummy de controle estatal do banco $i$ no ano $t$.

$B_{i, t}=$ é a vetor das características do banco $i \mathrm{em} t$.

$d t_{t}=$ são as dummies de tempo trimestrais de 2005 a 2013.

$c_{i}=$ fator de erro não observável constante em $t$ - "efeito específico dos bancos".

$\varepsilon_{i, t}=$ fator de erro não observável variante em $t$.

Podem-se interpretar os coeficientes da regressão no modelo (6) como: $\alpha_{2}$ mensura a mudança nos empréstimos dos bancos privados durante a época de crise, relativamente ao período base. Já o coeficiente $\alpha_{G 1}$ representa a diferença entre as taxas de crescimentos dos empréstimos dos bancos públicos e bancos privados durante o período base (précrise), e $\alpha_{G 2}$ é a mesma diferença, porém em época de crise comparado ao período base, logo, se positivo, confirma-se que os bancos públicos apresentaram a média de crescimentos de empréstimos maior que os privados durante a crise, compatível com a hipótese " 1 ".

Os demais coeficientes das variáveis de controle são: $\alpha_{0}$ representa o efeito do crescimento dos empréstimos defasados no crescimento dos empréstimos do período atual, $\alpha_{3}$ captura o impacto das variáveis dos bancos sobre o crescimento dos empréstimos. 


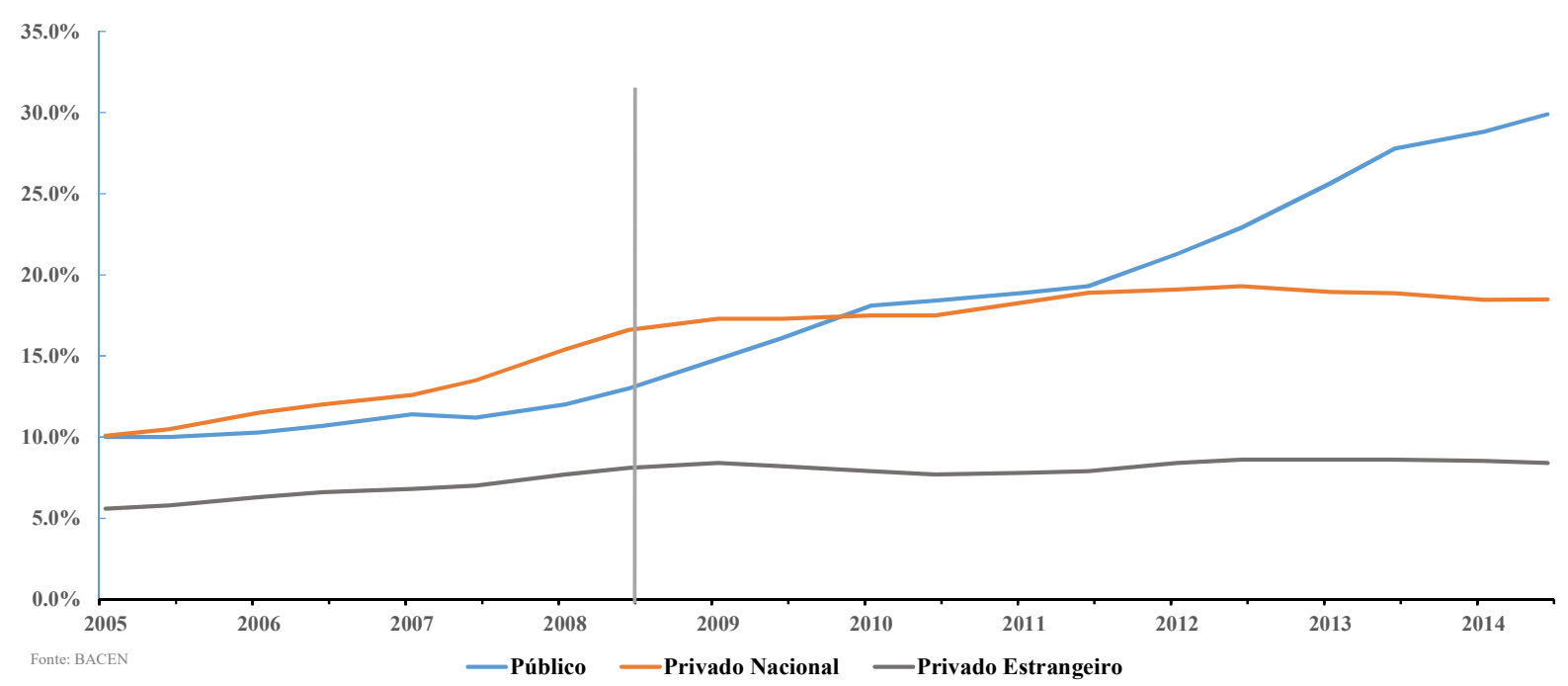

Figura 2. Crédito SFN/PIB - Por Controle

Na hipótese 2 o objetivo é verificar se durante a crise houve aumento da participação do crédito direcionado, e se este aumento foi maior para os bancos privados. Neste momento no modelo (8) abaixo há a separação do crédito em recursos direcionados e livres. $\mathrm{O}$ foco desta hipótese está na parcela do direcionado, e qual foi seu papel durante este período.

A figura 3 indica crescimento com relação ao PIB do crédito do SFN dos créditos classificados como livre e direcionado, nota-se crescimento modesto para as duas categorias, porém crescimento maior para o livre com relação ao valor do PIB.

Um ponto que poderia também contribuir para o aumento da participação do crédito direcionando são os mecanismos de direcionamento voluntário. Durante a crise, as instituições financeiras podem preferir utilizar-se das garantias oferecidas pelo governo, como seguro de créditos, subsídios aos juros ou garantias (Torres Filho, 2009), garantindo baixa rentabilidade (taxas subsidiadas), porém baixo risco de default. 


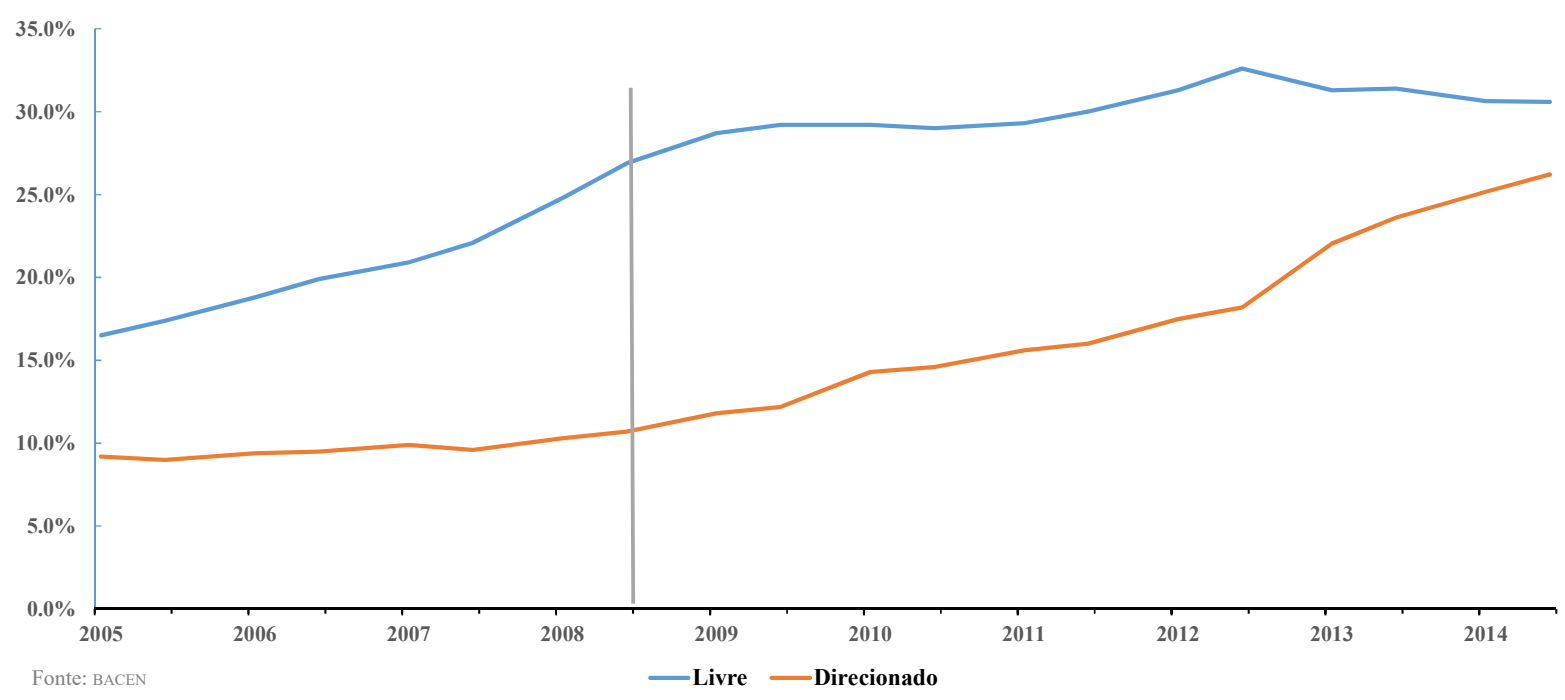

Figura 3. Crédito do SFN/PIB - Livre versus direcionado

O ponto central a despeito da magnitude do direcionamento (maior) para os bancos privados é que se a oferta total de empréstimos diminuiu, a expectativa é de que grande parte desse decréscimo seja atribuída ao crédito livre, onde os bancos possuem mais poder de manobra. Logo a participação do crédito direcionado na oferta total de crédito aumenta (efeito denominador), embora os bancos possam optar por não cumprir as regras de direcionamento, arcando com as penalidades e custos decorrentes. Portanto se comprovado este aumento, reforça a hipótese "2.1".

Em suma, o que se ambiciona é entendimento de como o crédito direcionado contribui para estabilização da oferta de crédito em período de crise, confirmando ou não seu papel contracíclio da oferta público e/ou privado. Dessa forma, a equação para testar as hipóteses " 2 " e "2.1" é:

$P D_{i, t}=\beta_{1} P D_{i, t-1}+\left(\beta_{2}+\beta_{3} \operatorname{Cri}_{t}\right)+\left(\beta_{P 1}+\beta_{P 2} \operatorname{Cri}_{t}\right) \operatorname{Pri}_{i, t}+\beta_{4} B_{i, t}+\beta_{5} d t_{t}+c_{i}+\varepsilon_{i, t}$

onde as variáveis são:

$P D_{i, t}=$ é a divisão do total de créditos direcionados por total de créditos (livres+direcionados) do banco $i$ no tempo $t$. 
$P D_{i, t-1}=$ é a divisão do total de créditos direcionados por total de créditos (livres+direcionados) do banco $i$ no tempo $t-1$.

$\mathrm{Cri}_{t}=$ é a variável dummy para o período de setembro de 2008 a dezembro de 2009.

$P r i_{i t}=$ é a variável dummy para controle privado, assume valor um para os bancos de origem privada e zero para os demais, no tempo $t$.

$\mathrm{Cri}_{t} \operatorname{Pri}_{i t}=$ é a interação (multiplicação) da variável dummy de crise com a dummy de controle privado do banco $i$ no ano $t$.

$B_{i, t}=$ é a vetor das características do banco $i$ em $t$.

$d t_{t}=$ são as dummies de tempo trimestrais de 2005 a 2013.

$c_{i}=$ fator de erro não observável constante em $t$ - "efeito específico dos bancos".

$\varepsilon_{i, t}=$ fator de erro não observável variante em $t$.

Para análise da hipótese 2 e 2.1 (equação 8), o coeficiente $\beta_{2}$ mede a média da participação do crédito direcionado dos bancos públicos em épocas normais, e $\beta_{3}$ representa a mudança na participação do crédito direcionado desses bancos durante época de crise, relativos aos padrões de empréstimo em épocas normais, somando-se ambos os coeficientes: $\beta_{2}$ e $\beta_{3}$ temse média da participação dos direcionados durante a crise. Já o coeficiente $\beta_{P 1}$ representa a diferença entre a participação dos direcionados dos bancos privados e bancos públicos em tempos de estabilidade, e $\beta_{P 2}$ é a mesma diferença, porém em época de crise comparado à época normal, consequentemente se positivo, confirma-se que os privados apresentaram média de participação dos créditos direcionados maior que os públicos, compatível com a hipótese.

Os coeficientes das variáveis de controle são: $\beta_{1}$ representa o impacto da participação do crédito direcionado defasado na participação do período atual, $\beta_{4}$ mensura o impacto das variáveis dos bancos na participação do crédito direcionado.

Por fim a hipótese 3 verifica se os bancos com maior participação de direcionados em sua carteira de crédito aumentam mais, ou reduziram menos a quantidade total concedida de 
empréstimos durante a crise. Esta hipótese complementa a hipótese 2 ao testar se a oferta de crédito dos bancos que trabalham com mais direcionado tende a ser mais estável no cenário de crise.

$$
\begin{aligned}
\Delta E_{i, t}= & \delta_{1} \Delta E_{i, t-1}+\delta_{2}+\delta_{3} \operatorname{Cri}_{t}+\delta_{4} \operatorname{Pri}_{i, t}+\delta_{5} P D_{i, t-1}+\left(\delta_{6} \operatorname{Pri}_{i, t}+\delta_{7} P D_{i, t-1}+\right. \\
& \left.+\delta_{8} \operatorname{Pri}_{i, t} P D_{i, t-1}\right) \operatorname{Cri}_{t}++\delta_{9} P D_{i, t-1} \operatorname{Pri}_{i, t}+\delta_{10} B_{i, t}+c_{i}+\varepsilon_{i, t}
\end{aligned}
$$

onde,

$\Delta E_{i, t}=$ é taxa de crescimento do total dos empréstimos bancários (diferença entre o logaritmo dos empréstimos $t$ - 1 e logaritmo dos empréstimos no tempo $t-1$ ) do banco $i$.

$\Delta E_{i, t-1}=$ é taxa de crescimento do total dos empréstimos bancários (diferença entre o logaritmo dos empréstimos $t$ - 1 e logaritmo dos empréstimos no tempo $t$-2) do banco $i$.

$C r i_{t}=$ é a variável dummy para o período de setembro de 2008 a dezembro de 2009.

Pri $i_{i, t}=$ é a variável dummypara controle privado, assume valor um para os bancos de origem privada e zero para os demais, no tempo $t$.

$P D_{i, t-1}=$ é a divisão do total de créditos direcionados por total de créditos (livres+direcionados) do banco $i$ no tempo $t-1$.

$P D_{i, t-1} \mathrm{Cri}_{t}=$ é a interação (multiplicação) da variável de participação do crédito direcionado do banco $i$ no tempo $t$-1 com a dummy de crise no tempo $t$.

$P D_{i, t-1} \operatorname{Cri}_{t} \operatorname{Pr} i_{i, t}=$ é a interação (multiplicação) da variável de participação do crédito direcionado do banco $i$ no tempo $t-1$ com a dummy de crise no tempo $t$ e com a dummy para controle privado do banco $i$ no tempo $t$. 
$P D_{i, t-1} \operatorname{Pri}_{i, t}=$ é a interação (multiplicação) da variável de participação do crédito direcionado do banco $i$ no tempo $t$ - 1 com a dummy para controle privado do banco $i$ no tempo $t$.

$B_{i, t}=$ é a vetor das características do banco $i$ em $t$.

$d t_{t}=$ são as dummies de tempo trimestrais de 2005 a 2013.

$c_{i}=$ fator de erro não observável constante em $t$ - "efeito específico dos bancos".

$\varepsilon_{i, t}=$ fator de erro não observável variante em $t$.

Na equação 8 , o coeficiente $\delta_{2}$ é a taxa média de crescimento dos empréstimos dos bancos públicos em épocas normais, $\delta_{3}$ mensura a mudança nos empréstimos desses bancos durante época de crise, relativos aos padrões de empréstimo em épocas normais, somando-se ambos os coeficientes: $\delta_{2}+\delta_{3}$ tem-se a média de crescimento durante a crise. Já o coeficiente $\delta_{4}$ representa a taxa média de crescimento dos empréstimos dos bancos privados em relação aos públicos em não crise, e $\delta_{6}$ para época de crise comparada a não crise.

Os coeficientes que acompanham a variável "PD" podem ser interpretados como o impacto da participação do crédito direcionado defasado no crescimento dos empréstimos diferenciando o controle do banco e a época, como: $\delta_{5}$ dos bancos públicos em época de não crise, $\delta_{7}$ dos bancos públicos em época de crise comparada à época de normalidade, $\delta_{8}$ na mesma época, porém para bancos privados em relação aos públicos, $\delta_{9}$ para controle privado em relação ao público em época de não crise. Desta forma para contribuir com a hipótese “3.1" de que a magnitude foi maior para os bancos de propriedade privada é necessário verificar se $\delta_{8}$ é maior que zero.

Para os demais coeficientes das variáveis de controle são: $\delta_{1}$ representa o efeito do crescimento dos empréstimos defasados e $\delta_{10}$ o impacto das variáveis dos bancos no crescimento dos empréstimos do período atual. 


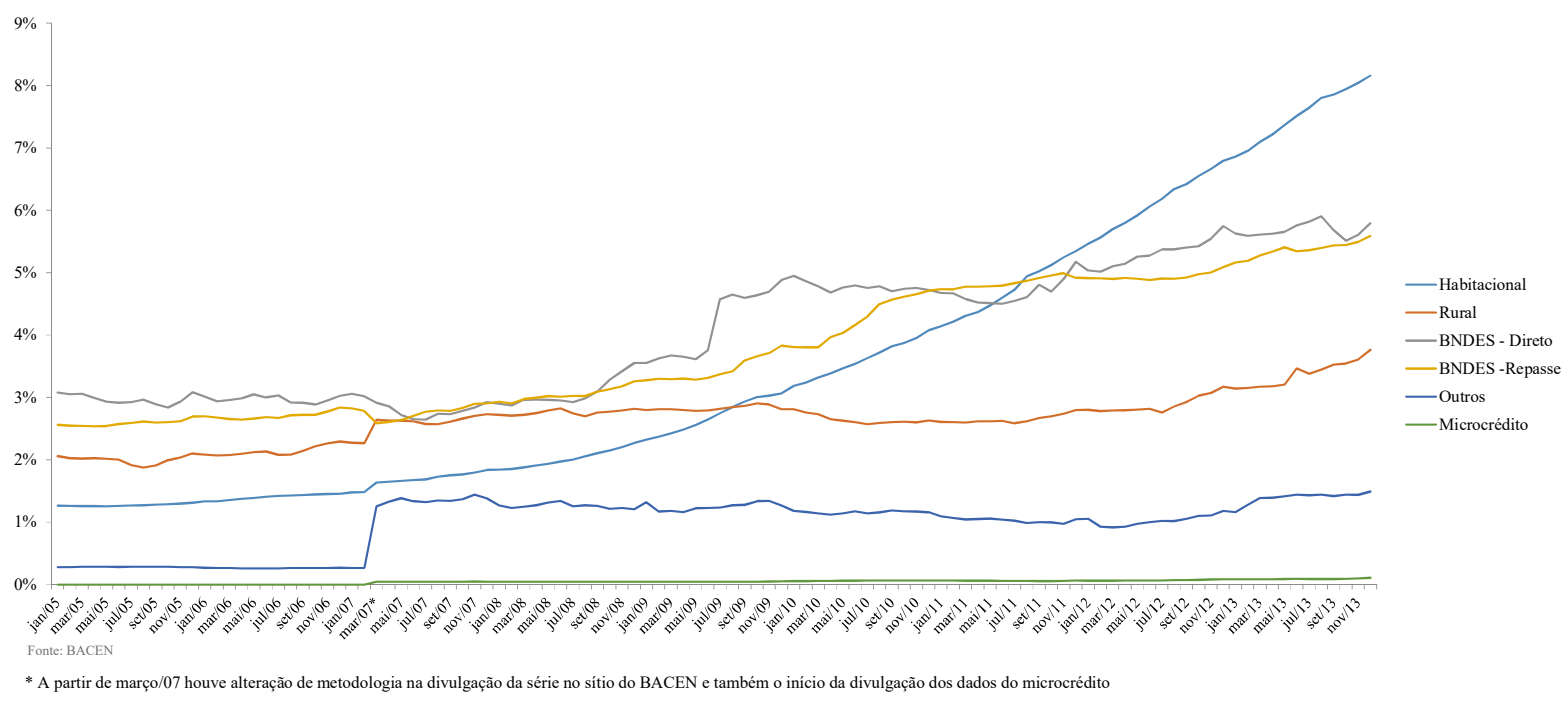

Figura 4. Crédito Direcionado do SFN/PIB - Pessoas Físicas e Jurídicas 


\section{RESUltAdos EMPÍRICOS}

\subsection{Estatística Descrita}

Neste subcapítulo é descrito como se comportam as variáveis utilizadas na pesquisa e como estas confirmam ou não as hipóteses testadas. Na Tabela 3 é apresentado o resumo de todas variáveis utilizadas, exceto as interações entre as variáveis. Nota-se que os números de observações das variáveis estão próximos, não iguais, pois as variáveis possuem construções diferentes, como crescimento, proporção e logaritmo, além de possuírem dados faltantes para alguns bancos e o número destes variarem ao longo do tempo, com entradas e saídas. Dentre os números que se apresentam na estatística descritiva de média, erro padrão, mínimo e máximo, a variável ‘tamanho' é a que possui maior valor por ser representada pelo logaritmo do total de ativo das instituições financeiras.

Tabela 3 - Estatística Descritiva

\begin{tabular}{lcccccccccc}
\hline & $\Delta$ Empréstimos & Part. Direcionado & $\Delta$ Depósitos & Liquidez & Capitalização & Tamanho & ROA & Crise & Governo & Privado \\
\hline Observações & 3,138 & 3,322 & 3,157 & 3,315 & 3,315 & 3,315 & 3,282 & 3,322 & 3,322 & 3,322 \\
Média & 0.35 & 0.19 & 0.04 & 0.29 & 0.21 & 21.53 & 0.69 & 0.17 & 0.11 & 0.89 \\
Desvio Padrão & 0.35 & 0.19 & 0.56 & 0.19 & 0.19 & 2.29 & 3.50 & 0.37 & 0.32 & 0.32 \\
Mínimo & -8.31 & 0.00 & -7.73 & 0.00 & -0.25 & 16.87 & -68.79 & 0.00 & 0.00 & 0.00 \\
Máximo & 4.89 & 1.00 & 10.50 & 1.00 & 0.99 & 27.79 & 24.95 & 1.00 & 1.00 & 1.00 \\
\hline
\end{tabular}

$\mathrm{Na}$ Tabela 4 encontram-se as correlações entre as variáveis. Para o crescimento dos empréstimos, percebe-se correlação significativa e positiva com as variáveis de crescimento dos depósitos e o $R O A$, já a capitalização e liquidez, embora significante, é negativamente correlacionado. Para as demais variáveis os valores não foram significativos. Já para a participação do crédito direcionado somente teve relação positiva e significante com o tamanho dos bancos. 
Tabela 4 - Correlações entre as variáveis

\begin{tabular}{|c|c|c|c|c|c|c|c|}
\hline & $\Delta$ Empréstimos & Part. Direcionado & $\Delta$ Depósitos & Liquidez & Capitalização & Tamanho & ROA \\
\hline$\Delta$ Empréstimos & 1.000 & & & & & & \\
\hline Part. Direcionado & -0.006 & 1.000 & & & & & \\
\hline$\Delta$ Depósitos & $0.104 * * *$ & 0.026 & 1.000 & & & & \\
\hline Liquidez & $-0.049 * * *$ & $-0.087^{* * *}$ & 0.024 & 1.000 & & & \\
\hline Capitalização & $-0.032 *$ & $-0.283^{* * *}$ & $-0.057^{* * *}$ & $-0.598^{* * *}$ & 1.000 & & \\
\hline Tamanho & -0.002 & $0.276^{* * *}$ & 0.004 & $-0.292 * * *$ & $-0.588 * * *$ & 1.000 & \\
\hline ROA & $0.072 * * *$ & 0.016 & $0.093 * * *$ & $-0.031^{*}$ & $0.029 *$ & $0.097 * * *$ & 1.000 \\
\hline
\end{tabular}

Nivel de significância, ${ }^{* * *}$ para $1 \%, * *$ para $5 \%$ e $*$ para $10 \%$

$\mathrm{Na}$ figura 5 encontra-se o valor do crédito separado pela categoria livre e direcionado e por tipo de controle em porcentagem do valor do PIB. Antes do período de crise o crescimento para os bancos públicos (livre e direcionados) e privados-direcionados foi relativamente constante. Já no que se refere a recursos livres com controle privado a trajetória foi de crescimento até o período mais agudo da crise (setembro 2008) com crescimento negativo até o início de 2009 onde o crédito livre retoma crescimento, entretanto a taxas menores do que o período anterior à crise.

$\mathrm{Na}$ categoria direcionado-privado o crescimento foi modesto, porém constante ao longo dos anos, com picos em meados de 2011 e 2013. Para os bancos privados pode-se conferir que após 2008 como a queda da parte livre, a participação do crédito direcionado aumentou, uma vez que o total de crédito diminuiu (numerador) e a quantidade de direcionado permaneceu relativamente estável (denominador). Esse argumento é favorável à hipótese 2, reforçando que o direcionado-privado contribuiu para estabilizar a oferta de crédito durante a crise financeira.

Do lado da oferta pública de crédito percebe-se aumento a partir de 2008, possivelmente em resposta ao declínio do livre-privado, conforme hipótese 1, com o crédito livre crescendo mais que o direcionado, situação que começa a se alterar ao longo dos anos e o volume de direcionado se torna maior que o livre a partir de meados de 2012. Uma possível resposta para o aumento do crédito direcionado-público é o aumento da participação do BNDES através dos repasses indiretos aos bancos públicos, infelizmente 
não se pode constatar através dos dados, pois conforme explicado neste trabalho, não há a separação do que é direcionado com e sem repasse.

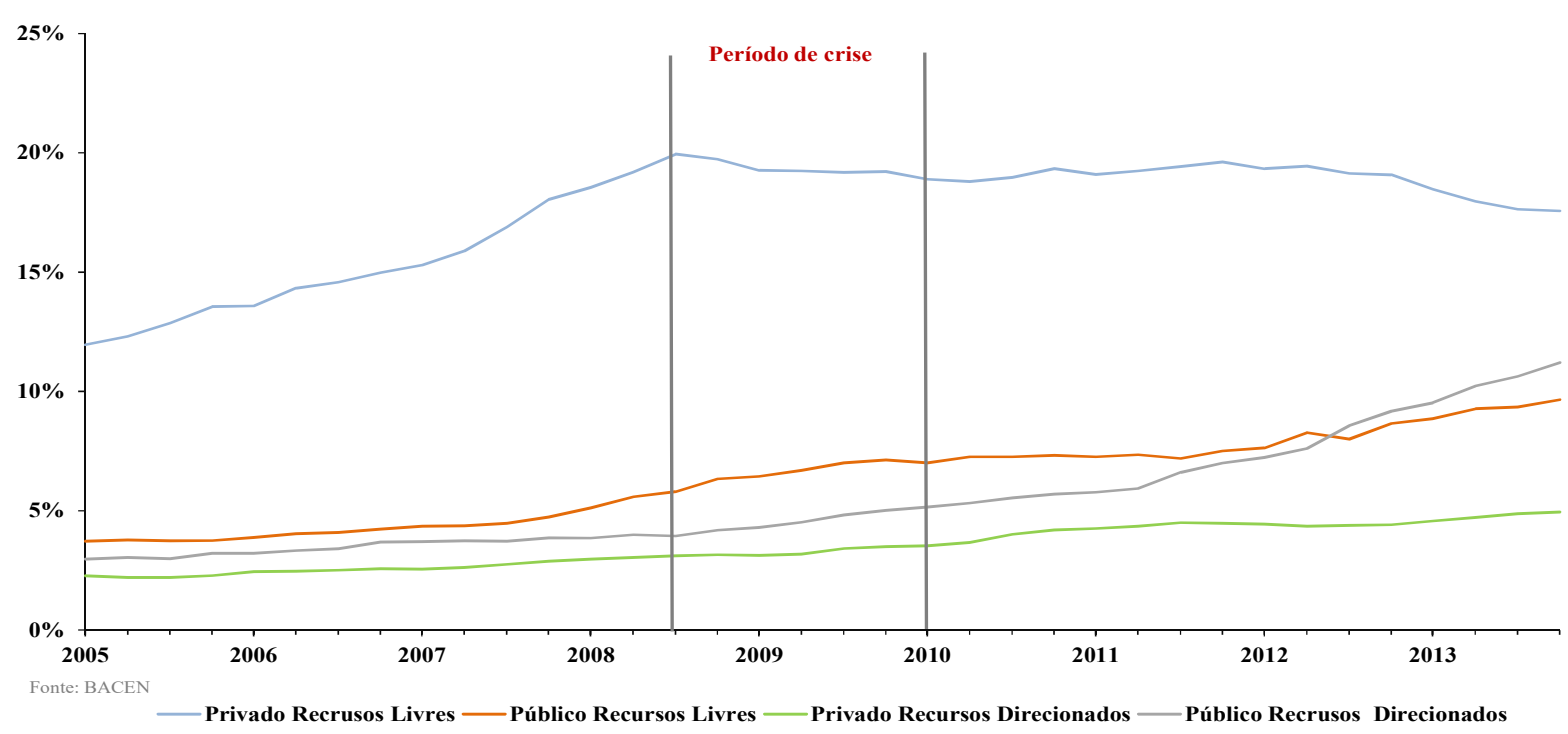

Figura 5. Recursos Livres e Direcionados por tipo de controle/PIB

\subsection{Resultado das Regressões}

Os modelos estimados neste trabalho para a verificação das hipóteses foram pelos métodos MQO e GMM-Sistêmico (Blundell \& Bond, 1998).

Os resultados do modelo apresentado na equação 7 estão reportados na Tabela 5. O coeficiente estimado para a variável crise é negativo e significante ao nível de $10 \%$ na estimação por $G M M$-Sistêmico, sugerindo que os bancos privados diminuíram a concessão de empréstimos durante a crise, preferindo reter liquidez a tomarem risco em operações de crédito. Desta forma, pode-se dizer que a crise financeira representou um ponto de inflexão para a oferta de crédito privado.

A dummy de governo, que indica a diferença no crescimento dos empréstimos dos bancos públicos e privados em época menor turbulência (crise $=0$ ), embora negativa para MQO, não foi significativa, dessa forma não se pode concluir tendência para o crescimento dos bancos públicos em relação aos privados. Possivelmente a não significância foi devido 
no pré-crise o crescimento ser maior para os bancos privados e no pós-crise para os bancos públicos, tornando a variável insignificante.

O coeficiente estimado da interação entre as dummies de crise e governo é significante ao nível de $1 \%$ em todas as regressões, sugerindo que durante a crise financeira os bancos estatais tiveram crescimento dos empréstimos maior em relação aos bancos privados, resultado compatível com a hipótese 1 em que o aumento dos bancos públicos na medida em que houve o declínio da concessão pelos bancos privados amenizou a oferta de crédito na economia.

A variável dependente defasada de crescimento dos empréstimos não foi significativa, possivelmente porque o crescimento do período passado não influencia a decisão presente da concessão de empréstimos.

Para as demais variáveis de controle, como esperado, o crescimento dos depósitos e o $R O A$ são positivos e significantes, ou seja, partes dos depósitos e dos lucros são convertidas em ativos através da concessão de crédito pelas instituições financeiras.

A liquidez e a capitalização não foram significativas, o que poderia explicar a não significância é que no período de crise os bancos com maior liquidez e maior capital retraíram o crédito, e desta forma durante todo o período não foi possível encontrar evidência estatística. Já o tamanho do banco foi negativo e somente significativo em GMM-Sistêmico, reforçando o argumento de Brei e Schlarek (2010) sobre os bancos pequenos se envolverem mais na concessão de empréstimos em relação aos bancos maiores. 
Tabela 5 - Resultado da hipótese 1

\begin{tabular}{|c|c|c|c|c|c|c|}
\hline & \multicolumn{3}{|c|}{ MQO } & \multicolumn{3}{|c|}{ GMM-System } \\
\hline Variáveis & Coeficiente & Erro Padrão & Estatística $t$ & Coeficiente & Erro Padrão & Estatística $t$ \\
\hline \multicolumn{7}{|l|}{ Dependente } \\
\hline \multicolumn{7}{|l|}{$\Delta$ Empréstimos } \\
\hline \multicolumn{7}{|l|}{ Independentes } \\
\hline Crise & -0.032 & 0.022 & -1.49 & $-0.043 *$ & 0.023 & -1.85 \\
\hline Governo & -0.004 & 0.013 & -0.28 & 0.030 & 0.024 & 1.26 \\
\hline GovernoXCrise & $0.077 * * *$ & 0.019 & 3.99 & $0.066 * * *$ & 0.023 & 2.81 \\
\hline$\Delta$ Empréstimos $_{\mathrm{t}-1}$ & -0.076 & 0.084 & -0.91 & -0.100 & 0.084 & -1.20 \\
\hline$\Delta$ Depósitos & $0.071 * *$ & 0.027 & 2.58 & $0.069 * *$ & 0.033 & 2.12 \\
\hline Liquidez & -0.065 & 0.055 & -1.18 & -0.071 & 0.090 & -0.78 \\
\hline Capitalização & 0.031 & 0.069 & 0.46 & -0.035 & 0.108 & -0.32 \\
\hline Tamanho & -0.003 & 0.003 & -0.93 & $-0.022 * *$ & 0.009 & -2.38 \\
\hline ROA & $0.006 * * *$ & 0.002 & 3.67 & $0.008 * * *$ & 0.002 & 4.35 \\
\hline Constante & 0.104 & 0.079 & 1.32 & $0.531 * *$ & 0.216 & 2.45 \\
\hline \multicolumn{7}{|l|}{ Outras Estatísticas } \\
\hline Dummies de tempo & $\operatorname{Sim}$ & & & Sim & & \\
\hline \# observações & 2,956 & & & 2,956 & & \\
\hline R-quadrado & 0.052 & & & - & & \\
\hline $\mathrm{F}$ & 2.95 & & & 3.68 & & \\
\hline F (p-value) & 0.000 & & & 0.000 & & \\
\hline \# bancos & 122 & & & 122 & & \\
\hline Hansen & - & & & 91.35 & & \\
\hline Hansen (p-value) & - & & & $>0.999$ & & \\
\hline \multicolumn{7}{|c|}{$\begin{array}{l}\text { As colunas } 1 \text { e } 2 \text { mostram os resultados da estimação da equação } 7 \text { pelo método MQO e GMM-Sistêmico (one-step). A variável } \\
\text { dependente é o crescimento dos empréstimos dos bancos e juntamente com os regressores está definida na Tabela } 5 \text {. Admite-se que as } \\
\text { dummies de crise, de governo e a interação entre ambas são exógenas. Também foram consideradas nas regressões: dummies de tempo } \\
\text { (exógenas), dados agrupados por bancos e a forma robusta para heterocedasticidade e autocorrelação entre os erros. O teste Hansen } \\
\text { avaliou os instrumentos, com a estatística e o p-value informados acima na tabela. Nível de significância, *** para } 1 \% \text {, ** para } 5 \% \text { e par } \\
10 \% \text {. }\end{array}$} \\
\hline
\end{tabular}

Para verificação da hipótese 2, o modelo estimado é apresentado na equação 8 e os resultados se encontram na Tabela 6. Do lado da oferta pública, o coeficiente da dummy de crise, que representa a mudança da participação do crédito direcionado dos bancos públicos durante época de instabilidade, foi negativo, porém insignificante para MQO e GMM-Sistêmico, ou seja, não é possível concluir através dos dados que houve uma tendência para o comportamento da participação do direcionado. Uma possível resposta é que durante esse período, a participação do crédito dos bancos públicos, proporção do valor dos direcionados sobre o total de créditos (direcionado mais livres), tenha se mantido estável, com pouca variação, o que também pode ser notado na Figura 5.

Já a oferta privada, prevista na hipótese 2.1, é explicada pelo coeficiente da interação entre as dummies de privado e de crise. Embora com evidência apenas para o modelo 
GMM-Sistêmico (variável positiva e significante a 10\%), pode-se notar que a participação do crédito direcionado dos bancos privados foi maior durante a crise em comparação a participação dos bancos públicos. A suposição é de que durante a crise, a participação do direcionado aumentou devido ao decréscimo da parte livre e/ou manutenção da parte direcionada. Já em ambiente de estabilidade financeira não se pode constatar que a participação do direcionado dos bancos privados é maior que a dos bancos públicos, pois o coeficiente da dummy de privado foi positiva, porém insignificante.

O coeficiente do crescimento dos depósitos não foi significante pela estimação de MQO e GMM-Sistêmico. A justificativa é de que ao aumentar os depósitos, o volume dos direcionados deve aumentar, dado a obrigatoriedade, em um mesmo momento os bancos são incentivados também a aumentarem o volume dos créditos livres, desta forma a participação de crédito direcionado pode aumentar e diminuir em proporções modestas ou se manter estável, a depender do valor da parcela dos depósitos que vai para direcionados e livres.

As variáveis capitalização, tamanho e ROA não foram boas determinantes da participação do direcionado, o que se pode concluir é que o tamanho do patrimônio, do ativo e do lucro das instituições financeiras pouco influencia na participação do direcionado. Entretanto o coeficiente da variável liquidez foi positivo e significante em 1\% em GMM-Sistêmico, indicando possível influência na participação do crédito direcionado, a depender também da proporção em que influencia o crescimento da parte do crédito livre e direcionado. 
Tabela 6 - Resultado da hipótese 2

\begin{tabular}{|c|c|c|c|c|c|c|}
\hline & \multicolumn{3}{|c|}{ MQO } & \multicolumn{3}{|c|}{ GMM-System } \\
\hline Variáveis & Coeficiente & Erro Padrão & Estatística $t$ & Coeficiente & Erro Padrão & Estatística $t$ \\
\hline \multicolumn{7}{|l|}{ Dependente } \\
\hline \multicolumn{7}{|l|}{$\Delta$ Participação de Direcionado } \\
\hline \multicolumn{7}{|l|}{ Independentes } \\
\hline Crise & -0.011 & 0.007 & -1.57 & -0.007 & 0.008 & -0.86 \\
\hline Privado & 0.004 & 0.005 & 0.89 & 0.004 & 0.031 & 0.13 \\
\hline PrivadoXCrise & 0.010 & 0.007 & 1.49 & $0.012 *$ & 0.007 & 1.75 \\
\hline Participação de Direcionado $_{t-1}$ & $0.980 * * *$ & 0.007 & 131.44 & $0.702 * * *$ & 0.200 & 3.51 \\
\hline$\Delta$ Depósitos & -0.005 & 0.005 & -0.92 & 0.004 & 0.018 & 0.24 \\
\hline Liquidez & 0.026 & 0.023 & 1.15 & $0.133 * *$ & 0.061 & 2.19 \\
\hline Capitalização & -0.026 & 0.024 & -1.08 & -0.142 & 0.168 & -0.84 \\
\hline Tamanho & 0.000 & 0.001 & -0.5 & 0.006 & 0.009 & 0.69 \\
\hline $\mathrm{ROA}$ & 0.000 & 0.000 & -0.6 & 0.002 & 0.003 & 0.60 \\
\hline Constante & 0.015 & 0.019 & 0.78 & -0.096 & 0.248 & -0.39 \\
\hline \multicolumn{7}{|l|}{ Outras Estatísticas } \\
\hline Dummies de tempo & $\operatorname{Sim}$ & & & Sim & & \\
\hline \# observações & 1,926 & & & 1,926 & & \\
\hline R-quadrado & 0.948 & & & - & & \\
\hline $\mathrm{F}$ & $3,282.01$ & & & 23.02 & & \\
\hline F (p-value) & 0.000 & & & 0.000 & & \\
\hline \# bancos & 86 & & & 86 & & \\
\hline Hansen & - & & & 40.64 & & \\
\hline Hansen (p-value) & - & & & $>0.999$ & & \\
\hline
\end{tabular}

As colunas 1 e 2 mostram os resultados da estimação da equação 8 pelo método MQO e GMM-Sistêmico (one-step). A variável dependente é a participação do crédito direcionado dos bancos e juntamente com os regressores está definida na Tabela 2 . Admite-se que as dummies de crise, de privado e a interação entre ambas são exógenas. Também foram consideradas nas regressões: dummies de tempo (exógenas), dados agrupados por bancos e a forma robusta para heterocedasticidade e autocorrelação entre os erros. O teste Hansen avaliou os instrumentos, com a estatística e o p-value informados acima na tabela. Nível de significância, *** para $1 \%, * *$ para $5 \%$ e $*$ para $10 \%$.

Com o intuito de verificar a hipótese 3 e 3.1, se os bancos com maior participação do crédito direcionado na carteira total de créditos contribuíram positivamente para o crescimento dos créditos no período de crise e se a contribuição foi maior para os bancos privados, foi estimado a equação 9 pelos métodos MQO e GMM-Sistêmico. Os resultados estão expostos na Tabela 7 e mostram que para os bancos públicos não se pode constatar que a participação do direcionado foi importante para o crescimento do crédito, em nenhum dos modelos o coeficiente da variável de interação entre a participação do direcionado defasada e a dummy de crise foi estatisticamente significante nos níveis convencionais.

Para os bancos privados que aumentaram a participação de crédito direcionado durante a crise, hipótese 2, também não foi possível comprovar através dos dados que aqueles que 
possuíam em sua carteira maior participação de crédito direcionado impactaram em maior proporção o crescimento dos empréstimos em relação aos bancos públicos, hipótese 3.1, o que pode ser visto no coeficiente da variável de interação de participação do direcionado defasada, dummy de crise e privado, que embora positivo, não foi significante em nenhum dos modelos. Em suma, pode-se supor que a participação do crédito direcionado tanto para os bancos públicos quanto para os privados não foi tão significativa a ponto de contribuir positivamente para o crescimento da oferta total de empréstimos.

Outra inferência a respeito do resultado do coeficiente da variável de interação de participação do direcionado defasada e a dummy de privado que foi negativo e significante no modelo $G M M$-Sistêmico ao nível de $10 \%$ de significância, é de que em épocas de estabilidade os bancos privados que mais possuem participação do crédito direcionado apresentam menor taxa média de crescimento dos empréstimos. O coeficiente da variável de controle participação do direcionado defasada, significante a $10 \%$ em GMMSistêmico, indica que independente da época e do controle dos bancos, os que mais possuem participação de direcionado no tempo passado contribuem no tempo presente com o crescimento dos empréstimos.

Os resultados para as variáveis de interesse, dummy de crise, dummy de privado e a interação entre ambas as variáveis foram similares aos apresentados na análise de hipótese 1. O mesmo pode-se dizer a respeito dos resultados e conclusões dos coeficientes das variáveis de controle: crescimento dos empréstimos defasados, crescimento dos depósitos e ROA. Diferentemente do modelo da hipótese 1 , os coeficientes de liquidez e capitalização foram negativos e significantes a $1 \%$ e $10 \%$ respectivamente, no modelo GMM-Sistêmico, conforme esperado o sinal dessas variáveis são ambíguos, o que pode influenciar na significância, porém para este modelo sugere que quanto maior a liquidez e a capitalização das instituições financeiras o impacto sobre o crescimento dos empréstimos é negativo.

Em relação a hipótese 1, no modelo GMM-Sistêmico as seguintes variáveis perderam a significância neste modelo, como a variável tamanho e também a constante, que indica a 
taxa média de crescimento dos empréstimos dos bancos públicos em épocas de estabilidade, para ambas as variáveis os sinais dos coeficientes se mantiveram.

Nota-se que em todos os modelos de regressões foram utilizadas variáveis dummies de tempo para controlar efeitos macroeconômicos comuns a todos os bancos. E o teste de sobreidentificação validou os instrumentos utilizados na regressão pelo $G M M$-Sistêmico.

\section{Tabela 7 - Resultado da hipótese 3}

\begin{tabular}{|c|c|c|c|c|c|c|}
\hline & \multicolumn{3}{|c|}{ MQO } & \multicolumn{3}{|c|}{ GMM-System } \\
\hline Variáveis & Coeficiente & Erro Padrão & Estatística $t$ & Coeficiente & Erro Padrão & Estatística $t$ \\
\hline \multicolumn{7}{|l|}{ Dependente } \\
\hline \multicolumn{7}{|l|}{$\Delta$ Empréstimos } \\
\hline \multicolumn{7}{|l|}{ Independentes } \\
\hline Crise & $0.033^{*}$ & 0.019 & 1.77 & $0.402 *$ & 0.237 & 1.70 \\
\hline Privado & 0.015 & 0.018 & 0.8 & $0.562 *$ & 0.331 & 1.69 \\
\hline PrivadoXCrise & $-0.073 * * *$ & 0.022 & -3.34 & $-0.464 *$ & 0.242 & -1.92 \\
\hline Participação de Direcionado ${ }_{t-1}$ XCrise & 0.047 & 0.046 & 1.02 & -1.310 & 0.869 & -1.51 \\
\hline Participação de Direcionado $_{\mathrm{t}-1} \mathrm{XCriseXPrivado}$ & 0.033 & 0.074 & 0.44 & 1.431 & 0.883 & 1.62 \\
\hline Participação de Direcionado ${ }_{t-1} X$ Privado & -0.077 & 0.058 & -1.33 & $-2.495^{*}$ & 1.283 & -1.95 \\
\hline$\Delta$ Empréstimos $_{\mathrm{t}-1}$ & -0.077 & 0.084 & -0.92 & -0.078 & 0.072 & -1.08 \\
\hline Participação de Direcionado $_{t-1}$ & 0.013 & 0.042 & 0.3 & $2.252^{*}$ & 1.259 & 1.79 \\
\hline$\Delta$ Depósitos & $0.070^{* *}$ & 0.027 & 2.57 & $0.059^{* *}$ & 0.027 & 2.17 \\
\hline Liquidez & -0.065 & 0.054 & -1.2 & $-0.665^{* * *}$ & 0.182 & -3.66 \\
\hline Capitalização & 0.019 & 0.071 & 0.26 & $-0.823^{*}$ & 0.439 & -1.87 \\
\hline Tamanho & -0.003 & 0.003 & -0.95 & -0.062 & 0.048 & -1.27 \\
\hline ROA & $0.006 * * *$ & 0.002 & 3.63 & 0.008 & 0.005 & 1.56 \\
\hline Constante & 0.102 & 0.076 & 1.34 & 1.183 & 1.121 & 1.06 \\
\hline \multicolumn{7}{|l|}{ Outras Estatísticas } \\
\hline Dummies de tempo & $\operatorname{Sim}$ & & & Sim & & \\
\hline \# observações & 2,956 & & & 2,956 & & \\
\hline R-quadrado & 0.054 & & & - & & \\
\hline $\mathrm{F}$ & 2.700 & & & 2.800 & & \\
\hline F (p-value) & 0.000 & & & 0.000 & & \\
\hline \# bancos & 122 & & & 122 & & \\
\hline Hansen & - & & & 89.32 & & \\
\hline Hansen (p-value) & - & & & $>0.999$ & & \\
\hline \multicolumn{7}{|c|}{$\begin{array}{l}\text { As colunas } 1 \text { e } 2 \text { mostram os resultados da estimação da equação } 9 \text { pelo método MQO e GMM-Sistêmico (one-step ). A variável dependente é o } \\
\text { crescimento dos empréstimos dos bancos e juntamente com os regressores está definida na Tabela } 2 \text {. Admite-se que as dummies de crise, de privado, a } \\
\text { interação entre ambas, a interação entre dummy de crise e participação de direcionado defasada, a interação entre dummy de privado e participação de } \\
\text { direcionado defasada, e a interação entre dummy de privado, dummy de crise e participação de direcionado defasada são exógenas. Também foram } \\
\text { consideradas nas regressões: dummies de tempo (exógenas), dados agrupados por bancos e a forma robusta para heterocedasticidade e autocorrelação entre } \\
\text { os erros. O teste Hansen avaliou os instrumentos, com a estatística e o p-value informados acima na tabela. Nível de significância, *** para } 1 \% \text {, ** para } 5 \% \\
\text { e * para } 10 \% \text {. }\end{array}$} \\
\hline
\end{tabular}




\section{CONSIDERAÇÕES FINAIS}

O atual trabalho buscou avaliar o impacto dos créditos ofertados pelos bancos públicos e do crédito direcionado durante a mais recente crise. Para tanto se baseou em análise empírica aplicada a partir dos bancos que ofertam empréstimos livres e direcionados e tomadores de depósitos, a amostra foi composta pelos bancos que compõe o Sistema Financeiro Nacional do período de 2005 a 2013.

Tomando por base aspectos conceituais sobre a intervenção do governo, este trabalho procurou responder a seguinte questão de pesquisa "Os bancos públicos e os mecanismos de direcionamento são importantes para suavizar a oferta de crédito quando há contração da oferta privada"?

A primeira parte dos resultados indica mudança no papel do governo com relação à concessão de crédito durante o período de crise 2008. Os resultados sugerem que se por um lado os bancos privados retraíram os empréstimos, possivelmente em retorno os bancos estatais aumentaram fortemente o crédito, balanceando a quantidade disponível no mercado de crédito como forma de conter piores consequências da crise global no Brasil.

Conforme já visto neste trabalho, a literatura a respeito é dividida com relação aos benefícios da participação mais ativa do governo através dos bancos públicos. Parte dos argumentos indica que o controle estatal se associa às distorções na alocação de recursos, deprimindo o desenvolvimento financeiro, e outros recomendam que a maior participação possa diminuir falhas como, por exemplo, financiamento de projetos socialmente desejáveis.

Esta pesquisa, com resultados modestos, ficou longe de sugerir qualquer ponto ideal de intervenção do governo via bancos públicos. A realidade de cada país/economia é bem mais complexa do que a parte que este estudo se propôs a analisar, entretanto em um cenário de crise financeira, associada ao alto grau de incerteza dos agentes, principalmente as instituições financeiras, o aumento da concessão de crédito pelos 
bancos públicos esteve associado à contenção de recursos que poderiam prejudicar ainda mais a crise.

Com relação à segunda parte, pode-se verificar também que durante a crise financeira os bancos privados aumentaram sua participação de crédito direcionado, seja pela diminuição na categoria de crédito livre (denominador menor, efeito participação maior) ou pelo aumento modesto ou manutenção da categoria de crédito direcionado, embora este efeito não tenha sido tão relevante economicamente.

No período de crise os bancos privados poderiam também ter expectativa de que o crédito direcionado fosse tão arriscado quanto o livre e dessa forma preferirem frear a concessão de crédito arcando com os custos decorrentes, entretanto o resultado deste trabalho indica que isso não ocorreu, seja porque os custos esperados superaram os riscos ou porque os bancos consideram a operação de crédito aos setores cobertos pelo direcionamento um canal mais seguro e estável.

Adicionalmente a questão de pesquisa, foi investigado se os bancos que mais ofertavam crédito direcionado foram aqueles que mais contribuíram para o crescimento do crédito total durante a época de turbulência, entretanto não foram encontradas evidências, ou seja, os bancos com maior grau de participação no direcionado não foram os que mais contribuíram para o crescimento dos empréstimos naquele período.

Assim como na literatura sobre o impacto da intervenção do governo no mercado de crédito, os efeitos do mecanismo de direcionamento de crédito dividem opiniões. Ainda que este trabalho demostre que o crédito direcionado contribuiu para estabilizar os financiamentos em um cenário de escassez, é indispensável comentar que muitos problemas após a crise internacional (2009) na economia brasileira podem ter sido agravados pelos altos volumes de créditos concedidos pelos BNDES, pelo Banco do Brasil (agricultura) e Caixa Econômica (habitação - programa Minha Casa, Minha Vida).

À medida que os créditos direcionados são ofertados a taxas subsidiadas isso afeta não somente o Orçamento da União (desiquilíbrio entre receitas e despesas), como também o 
aumento da taxa básica de juros (Selic) e consequentemente maior dificuldade no combate à inflação e crescimento econômico, prejudicando principalmente os setores não beneficiados pelo crédito direcionado.

Por fim, as evidências, embora modestas, indicam que a diversidade de bancos e os mecanismos de direcionamento podem assegurar um bom funcionamento do sistema financeiro, principalmente em períodos de crise. Contudo muito ainda pode ser estudado sobre o impacto dos bancos públicos e dos créditos direcionados. Novamente vale ressaltar que não há fórmula, ou quantidade ideal de intervenção, este trabalho indica, que sob determinado aspecto, os bancos públicos e os mecanismos de direcionamento de crédito foram responsáveis por um conforto na economia durante a recessão.

Como contribuição às pesquisas futuras sugere-se a extensão deste trabalho. Conforme já comentado, pesquisas poderiam se concentrar no papel dos bancos de desenvolvimento durante a crise. Adicionalmente analisar o crédito direcionado por setores como, por exemplo, os depósitos de poupança que devem cobrir o setor da habitação e o depósito à vista o rural e microcrédito e verificar se durante esse período houve diferenciação na quantidade de crédito ofertada, se, por exemplo, o setor da habitação foi priorizado em relação ao rural e as possíveis explicações/causas.

Além disso, faz importante também um aprimoramento do modelo que determina a quantidade de crédito a ser concedida pelos bancos (incluindo os determinantes do crédito direcionado), como também já discutido neste trabalho, não foram considerados os possíveis efeitos do choque de demanda na crise, entretanto parte da diminuição da concessão de empréstimos pode ter sido influenciada também pela demanda dos agentes econômicos.

Outro ponto de extensão deste trabalho é o estudo mais apurado dos efeitos do aumento do crédito direcionado após a recessão no mercado de crédito e na economia, considerando os prós e contras desta alternativa com o intuito de melhor contribuir para decisões de política econômica e consequentemente desenvolvimento do país. 


\section{REFERÊNCIAS}

Aguirre, A. (1997). Uma nota sobre a transformação BOX-COX (No. 116). CEDEPLAR/FACE/UFMG.

Ait-Sahalia, Y., Andritzky, J., Jobst, A., Nowak, S., \& Tamirisa, N. (2012). Market response to policy initiatives during the global financial crisis. Journal of International Economics, 87(1), 162-177.

_., Jackowicz, K., \& Kowalewski, O. (2013). The Effects of Foreign and Government Ownership on Bank Lending Behavior During a Crisis in Central and Eastern Europe. Wharton Financial Institutions Center Working Paper, 13-25.

Allen, F., Hryckiewicz, A., Kowalewski, O., \& Tümer-Alkan, G. (2010). Transmission of bank liquidity shocks in loan and deposit markets: the role of interbank borrowing and market monitoring. Wharton Financial Institutions Center Working Paper, 10-28.

Alem, A. C., \& Cavalcanti, C. E. (2005). O BNDES e o apoio à internacionalização das empresas brasileiras: algumas reflexões. Revista do BNDES, 12(24), 43-76.

Ang, J. B. (2014). Innovation and financial liberalization. Journal of Banking \& Finance, 47, 214-229.

Annibal, C., Lundberg, E., \& Koyama, S. M. (2009). 1 Crise de 2008 e as Mudanças no Mercado de Crédito. Relatório de Economia Bancária e Crédito, 37.

Arellano, M., \& Bond, S. (1991). Some tests of specification for panel data: Monte Carlo evidence and an application to employment equations. The review of economic studies, 58(2), 277-297.

_, \& Bover, O. (1995). Another look at the instrumental variable estimation of errorcomponents models. Journal of econometrics, 68(1), 29-51. 
Arida, P. (2005). Mecanismos compulsórios e mercado de capitais: propostas de política econômica. Mercado de capitais e crescimento econômico: lições internacionais, desafios brasileiros. Rio de Janeiro: Contra Capa Livraria e Anbid, 205-214.

Aronovich, S., \& Fernandes, A. G. (2006). A atuação do governo no mercado de crédito: experiências de IFDs em países desenvolvidos. Revista do BNDES, 13(25), 3-34.

Banco Central do Brasil. (2014). Instituições Participantes do Crédito Rural. Recuperado em 15 de outubro de 2014, de http://www.bcb.gov.br/htms/creditorural/2012/rel61.pdf

_ (2014a). Instituições Captadoras de Depósito. Recuperado em 17 de outubro de 2014, de http://www.bcb.gov.br/fis/SFH/port/est2014/03/Quadro_1_3.pdf

_ (2014b). Busca de Normas. Recuperado em 25 de outubro de 2014, de http://www.bcb.gov.br/pre/normativos/novaBusca/buscaNormativo.asp

_ (2014c). 50 maiores bancos e o consolidado do Sistema Financeiro Nacional. $\begin{array}{lllllll}\text { Recuperado em de } & \text { de }\end{array}$ http://www4.bcb.gov.br/top50/port/esc_met_v1.asp

_ (2014d). Indicadores de crédito. Recuperado em 25 de outubro de 2014, de https://www3.bcb.gov.br/sgspub/localizarseries/localizarSeries.do?method=prepar arTelaLocalizarSerie

_ (2014e). Recolhimentos compulsórios, encaixe e direcionamentos obrigatórios. Recuperado em 19 de outubro de 2014, de http://www.bcb.gov.br/?COMPULSORIOS

_ (2015). O que é o SCR. Recuperado em 07 de abril de 2015, de http://www.bcb.gov.br/?SCROQUE 
_ (2014a). Instituição Financeira Credenciada. Recuperado em 22 de outubro de 2014, de http://www.bndes.gov.br/SiteBNDES/bndes/bndes_pt/Institucional/Instituicao_Fi nanceira_Credenciada/

_ (2014b). Composição dos Custos Financeiros. Recuperado em 22 de outubro de 2014, de http://www.bndes.gov.br/SiteBNDES/bndes/bndes_pt/Ferramentas_e_Normas/Cu stos_Financeiros/Composicao/

Barros, L. A. B. D. C. (2005). Decisões de financiamento e de investimento das empresas sob a ótica de gestores otimistas e excessivamente confiantes (tese de doutorado, Universidade de São Paulo).

Barth, J. R., Caprio, G., \& Levine, R. (2005). Rethinking bank regulation: Till angels govern. Cambridge University Press.

Bernardino, A. P. D. S. (2005). Fontes de recursos e atuação do BNDES sob uma perspectiva histórica. Revista do BNDES, 12(23), 53-72.

Blundell, R., \& Bond, S. (1998). Initial conditions and moment restrictions in dynamic panel data models. Journal of econometrics, 87(1), 115-143.

Bond, S. R. (2002). Dynamic panel data models: a guide to micro data methods and practice. Portuguese economic journal, 1(2), 141-162.

Bonomo, M., Brito, R., \& Martins, B. (2014). Macroeconomic and Financial Consequences of the After Crisis Government-Driven Credit Expansion in Brazil (No. 378).

Brei, M., \& Schclarek, A. (2013). Public bank lending in times of crisis. Journal of Financial Stability, 9(4), 820-830.

_.,\& Schclarek,A. (2015). A theoretical model of bank lending: Does ownership matter in times of crisis?. Journal of Banking \& Finance, 50, 298-307. 
Bresser-Pereira, L. C. (2010). A crise financeira global e depois: um novo capitalismo?. Novos Estudos-CEBRAP, (86), 51-72.

Bucher, M., Dietrich, D., \& Hauck, A. (2013). Business cycles, bank credit and crises. Economics Letters, 120(2), 229-231.

Caetité, A. N., Stranchman, E., \& Costa, G.R.B. (2009).Convenções Preferência pela Liquidez e Volume de Crédito Bancário, no Brasil, no Período 1996-2008. II Encontro Internacional de Associação Keynesiana Brasileira. (02. Set 2009).

Carvalho, F. C. D. (2009). O retorno de Keynes. Novos Estudos-CEBRAP, (83), 91-101.

Cestare, A. B. (2007). O impacto das políticas de direcionamento de crédito e de depósitos compulsórios no mercado bancário.

Cintra, M. A. M. (2006). A reestruturação patrimonial do sistema bancário brasileiro e os ciclos de crédito entre 1995 e 2005. A supremacia dos mercados e a política econômica do governo Lula. São Paulo: Editora Unesp, 321-46.

_(2009). Crédito público e desenvolvimento econômico: a experiência brasileira. Ensaios sobre economia financeira. Rio de Janeiro: BNDES, 57-108.

_, \& Farhi, M. (2008). A crise financeira e o global shadow banking system. Novos estudos-CEBRAP, (82), 35-55.

Clair, R. T., \& Tucker, P. (1993). Six causes of the credit crunch. Federal Reserve Bank of Dallas Economic Review, 3, 1-19.

Corazza, G. (2000). Crise e reestruturação bancária no Brasil. XXVIII Encontro Nacional de Economia. Campinas, ANPEC, 12 a 15 de dezembro.

Cornett, M. M., McNutt, J. J., Strahan, P. E., \& Tehranian, H. (2011). Liquidity risk management and credit supply in the financial crisis. Journal of Financial Economics, 101(2), 297-312. 
Costa, S. M. D. A. (2011). Intervenções do Estado sobre o mercado bancário e os tradeoffs entre eficiência, resiliência financeira e estabilidade macroeconômica, Dissertação de doutorado, Universidade de São Paulo, São Paulo, Brasil.

Costa, A. C., \& Lundberg, E. (2004). Direcionamentos de crédito no Brasil: uma avaliação das aplicações obrigatórias em crédito rural e habitacional. Economia bancária e crédito: avaliação de, 5 anos do Projeto Juros e Spread Bancário, 49-62.

_, \& Nakane, M. I. (2005). Crédito direcionado e custo das operações de crédito livre: uma avaliação do subsídio cruzado do crédito imobiliário e rural no Brasil. Relatório de Economia Bancária e Crédito. Brasília: BCB, 29-43.

Dawid, P. E., \& Takeda, T. (2011). Recolhimentos compulsórios e o crédito bancário brasileiro. Banco Central do Brasil, Working Paper Series, (250).

De Freitas, M. C. P. (2007). Projeto de pesquisa: O Brasil na era da globalização: condicionantes domésticos e internacionais ao desenvolvimento.

_ (2009). Os efeitos da crise global no Brasil: aversão ao risco e preferência pela liquidez no mercado de crédito. Estudos Avançados, 23(66), 125-145.

De Paula, L. F., \& Lima, G. T. (1999). Teoria da firma bancária. LIMA, GT et alii. Macroeconomia moderna: Keynes e a economia contemporânea. Rio de Janeiro, Campus.

Diário do Nordeste (2012). Maioria do supremo vê fraude no Banco Rural. Recuperado $\begin{array}{llllll}\text { em } & 11 & \text { de } & \text { julho } & \text { de } & 2015 .\end{array}$ http://diariodonordeste.verdesmares.com.br/cadernos/nacional/maioria-dosupremo-ve-fraude-no-banco-rural-1.610254

Dietrich, A., \& Wanzenried, G. (2011). Determinants of bank profitability before and during the crisis: Evidence from Switzerland. Journal of International Financial Markets, Institutions and Money, 21(3), 307-327.

Dinç, I. S. (2005). Politicians and banks: Political influences on government-owned banks in emerging markets. Journal of Financial Economics, 77(2), 453-479. 
Estadão (2014). BC vê indícios de fraudes no BVA e suspeita de operações com o Petros. Recuperado em 11 de julho de 2015, de http://economia.estadao.com.br/noticias/geral,bc-ve-indicios-de-fraudes-no-bva-esuspeita-de-operacoes-com-o-petros, $186163 \mathrm{e}$

Fama, E. F. (1980). Banking in the Theory of Finance. Journal of monetary economics, $6(1), 39-57$.

Fiani, R. (1998). Teoria da regulação econômica: estado atual e perspectivas futuras. Teoria Política e Instituições de Defesa da Concorrência. Texto para Discussão $n^{\circ}$ 423, IE/UFRJ, Rio de Janeiro.

Fraga, J. S. (2009). Uma abordagem pós-keynesiana de preferência pela liquidez: o sistema bancário e a concessão de crédito. RACE-Revista de Administração, Contabilidade e Economia, 8(1), 155-174.

Freitas, M. C. P. D. (2009). The effect of the global crisis in Brazil: risk aversion and preference for liquidity in the credit market. Estudos Avançados, 23(66), 125-145.

Fucidji, J. R., \& Mendonça, D. D. P. (2006). Determinantes do Crédito Bancário: uma análise com dados em painel para as maiores instituições. UNESP/FCLAraraquara.

Fungáčová, Z., Herrala, R., \& Weill, L. (2013). The influence of bank ownership on credit supply: evidence from the recent financial crisis. Emerging Markets Review, 15, 136-147.

Gambacorta, L. (2005). Inside the bank lending channel. European Economic Review, 49(7), 1737-1759.

Gerali, A., Neri, S., Sessa, L., \& Signoretti, F. M. (2010). Credit and Banking in a DSGE Model of the Euro Area. Journal of Money, Credit and Banking, 42(s1), 107-141. 
Gerschenkron, A. (1962). Economic backwardness in historical perspective. Economic backwardness in historical perspective, Harvard University Press, Cambridge.

Gertler, M., \& Kiyotaki, N. (2010). Financial intermediation and credit policy in business cycle analysis. Handbook of monetary economics, 3(11), 547-599.

_, \& Karadi, P. (2011). A model of unconventional monetary policy. Journal of monetary Economics, 58(1), 17-34.

_, Kiyotaki, N., \& Queralto, A. (2012). Financial crises, bank risk exposure and government financial policy. Journal of Monetary Economics, 59, S17-S34.

Goodhart, C. A. (2008). The background to the 2007 financial crisis. International Economics and Economic Policy, 4(4), 331-346.

Gurley, J. G., \& Shaw, E. S. (1955). Financial aspects of economic development. The American Economic Review, 515-538.

Haldane, A. G., \& May, R. M. (2011). Systemic risk in banking ecosystems. Nature, 469(7330), 351-355.

Helbling, T., Huidrom, R., Kose, M. A., \& Otrok, C. (2011). Do credit shocks matter? A global perspective. European Economic Review, 55(3), 340-353.

Hermann, J. (2011). Bancos públicos em sistemas financeiros maduros: perspectivas teóricas e desafios para os países em desenvolvimento. Revista de economia política, 31(3), 394-414.

Instituto Brasileiro de Geografia e Estatística (2015). Série Histórica do PIB. Recuperado em 26 de julho de 2015, de http://www.ibge.gov.br/home/presidencia/noticias/imprensa/ppts/0000000776520 3112012522606619383.xls.

Instituto de Pesquisa Econômica Aplicada (2015).Tema: Emprego. Recuperado em 26 de julho de 2015, de http://www.ipeadata.gov.br/. 
ISTOÉ Independente (2013). Relatório final do BC mostra fraudes e grampos de um Banco que adorava ajudar políticos. Recuperado em 11 de julho de 2015, de http://www.istoe.com.br/reportagens/297699_RELATORIO+FINAL+DO+BC+M OSTRA+FRAUDES+E+GRAMPOS+DE+UM+BANCO+QUE+ADORAVA+AJ UDAR+POLITICOS

Ivashina, V., \& Scharfstein, D. (2010). Bank lending during the financial crisis of 2008. Journal of Financial economics, 97(3), 319-338.

Junior, G. R. B., \& Teixeira Filho, E. T. (2009). As Origens e Desdobramentos da Crise do Subprime. Francisco Marcelo Rocha Ferreira, 287.

Keynes, J. M. (1930). A Treatise on Money: In 2 Volumes. Macmillan \& Company.

_ (1971). The collected writings of John Maynard Keynes Vol. 5: A treatise on money: The pure theory of money. Macmillan.

Kishan, R. P., \& Opiela, T. P. (2000). Bank size, bank capital, and the bank lending channel. Journal of Money, Credit and Banking, 121-141.

Kohli, R. (1997). Directed Credit and Financial Reform. Economic and Political weekly, 2667-2676.

La Porta, R., Lopez-de-Silanes, F., \& Shleifer, A. (2002). Government ownership of banks. The Journal of Finance, 57(1), 265-301.

Llanto, G. M., Geron, P., \& Tang, C. (1999). Directed credit programs; issues and framework for reform. Manila, October.

Lundberg, E. L. (2011). Bancos Oficiais e Crédito Direcionado - o que diferencia o mercado de crédito brasileiro?. Central Bank of Brazil, Research Department, 258.

Marques, L. D. (2000). Modelos dinâmicos com dados em painel: revisão de literatura. Centro de Estudos Macroeconômicos e Previsão, Faculdade de Economia do Porto. 
Menezes-Filho, N., \& Vasconcellos, L. (2004). Has economic growth been pro-poor in Brazil? Why?. Paper prepared for the OPPG Work Program.

Mesquita, M., \& Torós, M. (2010). Considerações sobre a atuação do Banco Central na crise de 2008, Trabalhos para discussão, 202.

Mian, A., \& Sufi, A. (2010). The great recession: Lessons from microeconomic data. The American Economic Review, 51-56.

Micco, A., \& Panizza, U. (2006). Bank ownership and lending behavior. Economics Letters, 93(2), 248-254.

Miller, M. (2010). Political Economy of Directed Credit. Research Internship Paper, 14.

Milne, A., \& Wood, G. E. (2008). Banking crisis solutions old and new. Federal Reserve Bank of St. Louis Review, 90(September/October 2008).

Minsky Human, P. (1986). Stabilizing an unstable economy. Yale University Press.

Miwa, Y., \& Ramseyer, J. M. (2001). Directed Credit? Capital Market Competition in High-Growth Japan. Capital Market Competition in High-Growth Japan (September 2001). Harvard Law and Economics Discussion Paper, 334.

Mizen, P. (2008). The credit crunch of 2007-2008: a discussion of the background, market reactions, and policy responses. Federal Reserve Bank of St. Louis Review, 90(September/October 2008).

Modigliani, F., \& Miller, M. H. (1958). The cost of capital, corporation finance and the theory of investment. The American economic review, 261-297.

Nguyen, H., \& Qian, R. (2014). Demand collapse or credit crunch to firms? Evidence from the World Bank's financial crisis survey in Eastern Europe.Journal of International Money and Finance, 47, 125-144.

Nohara, J. J. (1997). Crise financeira: antigas e novas abordagens. Revista de Economia Política, 17(1), 65. 
O Globo. (2013). Brasil já gastou R $\$ 830$ bilhões para reduzir impactos da crise.Acessado em julho 7, 2014, em http://oglobo.globo.com/economia/brasil-ja-gastou-830bilhoes-para-reduzir-impactos-da-crise-9873617\#ixzz399kuquYR.

Odedokun, M. O. (1996). International evidence on the effects of directed credit programmes on efficiency of resource allocation in developing countries: The case of development bank lendings. Journal of Development Economics, 48(2), 449460.

Oliveira, R. D. F., Schiozer, R. F., \& Barros, L. A. D. C. (2015). Depositors' Perception of "Too-Big-to-Fail”*. Review of Finance, 19 (1) (2015), pp. 191-227.

_, Schiozer, R., \& Leão, S. (2012). Atuação de Bancos Estrangeiros no Brasil: mercado de crédito e de derivativos de 2005 a 2011 (No. 298). Central Bank of Brazil, Research Department.

Paula, L. F. D. (2007). Bancos e crédito: a abordagem pós-keynesiana de preferência pela liquidez. Revista de Economia, 32(2).

Pereira, L. C. B., \& LC, O. (1989). O caráter cíclico da intervenção estatal. Revista de Economia Política, 9(3), 115-130.

Perri, F., \& Quadrini, V. (2011). International recessions (No. w17201). National Bureau of EconomicResearch.

Pinheiro, M. M. S. (1997). O papel dos fundos parafiscais no fomento: FGTS e FAT. Texto para Discussão, 485, IPEA, Brasília.

Pissetti, J. A. W. (2012). The 2008 Financial Crisis and its effects on credit supply in the Brazilian banking system-The stabilizing role of public banks (No. 1209). Hochschulefuer Technikund Wirtschaft, Berlin.

Pochmann, M. (2009). O trabalho na crise econômica no Brasil: primeiros sinais. Estudos avançados, 23(66), 41-52. 
Prates, D. M., Cunha, A. M., \& Lélis, M. T. C. (2011). O Brasil e a crise financeira global: avaliando os canais de transmissão nas contas externas. Revista de Economia Contemporânea, 15(1), 62-91.

Prochnik, M., \& Machado, V. (2008). Fontes de recursos do BNDES 1995-2007. Revista do BNDES, 14(29), 3-34.

Roodman, D. (2006). How to do xtabond2: An introduction to difference and system GMM in Stata. Center for Global Development working paper, (103).

_ (2014). xtabond2: Stata module to extend xtabond dynamic panel data estimator. Statistical Software Components.

Sant'anna, A. A., Junior, G. R. B., \& de Araujo, P. Q. (2009). Mercado de crédito no Brasil: evolução recente e o papel do BNDES (2004-2008). Francisco Marcelo Rocha Ferreira, 151.

Sapienza, P. (2004). The effects of government ownership on bank lending. Journal of Financial Economics, 72(2), 357-384.

Schapiro, M. G. (2009). Novos parâmetros para a intervenção do Estado na economia: persistência e dinâmica da atuação do BNDES em uma economia baseada no conhecimento. Dissertação de Doutorado, Universidade de São Paulo, São Paulo, Brasil.

Schwarz, A. M. (1992). How Effective are Directed Credit Policies in the United States?: A Literature Survey (Vol. 1019). World Bank Publications.

Seabra, F., Giglio, R. F., Fernandes, R. L., \& Meurer, R. (2009). Existe comportamento diferenciado entre bancos públicos e privados em relação à política monetária?. Pesquisa \& Debate. Revista do Programa de Estudos Pós-Graduados em Economia Política. ISSN 1806-9029, 20(1 (35)).

Stiglitz, J.E.(1993). The role of the state in financial markets. Proceedings of the World Bank Annual Conference on Development Economics, 19-52. 
_, \& Greenwald, B. (2003). Towards a new paradigm in monetary economics. Cambridge University Press.

Taylor, J. B. (2009). The financial crisis and the policy responses: An empirical analysis of what went wrong (No. w14631). National Bureau of Economic Research.

Tobin, J. (1964). Commercial banks as creators of" money.". Cowles Foundation for Research in Economics at Yale University.

_ (1987). Essays in economics: Macroeconomics (Vol. 1). Mit Press.

Torres Filho, E. T. (2006). Crédito direcionado e direcionamento do crédito: situação atual e perspectivas. Revista do BNDES, 13.

_ (2009). Mecanismos de direcionamento do crédito, bancos de desenvolvimento e a experiência recente do BNDES. Francisco Marcelo Rocha Ferreira, 11.

Veja (2010). Fraude no Panamericano. Recuperado em 11 de julho de 2015, de http://veja.abril.com.br/infograficos/fraude-banco-panamericano/

Vittas, D., \& Wang, B. (1991). Credit policies in Japan and Korea: a review of the literature (No. 747). The World Bank.

Weill, L. (2003). Banking efficiency in transition economies. Economics of transition, 11(3), 569-592.

Wooldridge, J. M. (2010). Econometric analysis of cross section and panel data. MIT press.

Yeyati, E. L., Micco, A., \& Panizza, U. (2004). Should the government be in the banking business? The role of state-owned and development banks. Working Paper, InterAmerican Development Bank, Research Department, 517.

Zysman, J. (1984). Governments, markets, and growth: financial systems and the politics of industrial change (Vol. 15). Cornell University Press. 


\section{APÊNDICES}

Tabela 8 - Direcionamento de depósito de poupança Rural

\begin{tabular}{|c|c|c|c|c|c|c|}
\hline Resolução & Aplicação & $\begin{array}{c}\text { Bancos } \\
\text { Federais } \\
\text { (a) }\end{array}$ & $\begin{array}{c}\text { Bancos } \\
\text { Cooperativos }\end{array}$ & $\begin{array}{l}\text { Base de } \\
\text { Cálculo }\end{array}$ & $\begin{array}{l}\text { Período de } \\
\text { Cálculo }\end{array}$ & $\begin{array}{c}\text { Deficiência no } \\
\text { Direcionamento }\end{array}$ \\
\hline
\end{tabular}

\begin{tabular}{|c|c|c|c|c|c|c|}
\hline $\begin{array}{c}2.876 \text { de } \\
26 / 7 / 2001 \\
\end{array}$ & Jul/01 & \multirow{3}{*}{$\begin{array}{c}40 \% \text { sendo } \\
\text { que: } \\
\text { I - } 50 \% \text {, no } \\
\text { mínimo, do } \\
\text { percentual } \\
\text { referido, no } \\
\text { período de } \\
01 / 07 / 01 \text { a } \\
31 / 08 / 02 \text {; II } \\
\text { - } 75 \% \text {, no } \\
\text { mínimo, do } \\
\text { percentual } \\
\text { referido, no } \\
\text { período } \\
01 / 09 / 02 \text { a } \\
31 / 08 / 03 ; \text { III } \\
\text { - } 100 \% \text { do } \\
\text { percentual } \\
\text { referido, a } \\
\text { partir de } \\
01 / 09 / 03 \\
\end{array}$} & & \multirow{5}{*}{$\begin{array}{l}\text { Saldo médio } \\
\text { diário dos } \\
\text { depósitos } \\
\text { captados em } \\
\text { poupança } \\
\text { rural }\end{array}$} & \multirow{4}{*}{$\begin{array}{c}\text { Inicia no } \\
\text { primeiro dia } \\
\text { útil e término } \\
\text { no último dia } \\
\text { útil de cada } \\
\text { mês, } \\
\text { desprezando- } \\
\text { se os dias } \\
\text { não-úteis } \\
\text { contidos } \\
\text { nesse } \\
\text { intervalo }\end{array}$} & \multirow{6}{*}{$\begin{array}{c}\text { Fica a instituição } \\
\text { sujeita a } \\
\text { recolhimento: } \\
\text { I - do valor da } \\
\text { deficiência apurada, } \\
\text { que ficará retido até a } \\
\text { data da verificação } \\
\text { subsequente; ou até } \\
\text { que comprovada sua } \\
\text { recomposição; ou } \\
\text { II - de multa de } 20 \% \text {, } \\
\text { calculada sobre o } \\
\text { valor da deficiência } \\
\text { apurada }\end{array}$} \\
\hline $\begin{array}{c}2.971 \mathrm{de} \\
27 / 6 / 2002\end{array}$ & Jun/02 & & & & & \\
\hline $\begin{array}{c}3.103 \mathrm{de} \\
25 / 6 / 2003\end{array}$ & Set/03 & & - & & & \\
\hline $\begin{array}{c}3.188 \mathrm{de} \\
29 / 3 / 2004\end{array}$ & Set/04 & $\begin{array}{c}\text { I - } 50 \% \text { a } \\
\text { partir de } \\
01 / 09 / 04 ; \text { II } \\
\text { - 55\% a } \\
\text { partir de } \\
01 / 09 / 05 ; \text { III } \\
\text { - 60\% a } \\
\text { partir de } \\
01 / 09 / 06 ; \text { IV } \\
\text { - 65\% a } \\
\text { partir de } \\
01 / 09 / 07 \\
\end{array}$ & $65 \%$ & & & \\
\hline $\begin{array}{c}3.224 \mathrm{de} \\
29 / 7 / 2004\end{array}$ & Set/04 & $\begin{array}{c}\text { I - } 50 \% \text { a } \\
\text { partir de } \\
01 / 09 / 04 ; \text { II } \\
\text { - 55\% a } \\
\text { partir de } \\
01 / 08 / 05 ; \text { III } \\
\text { - 60\% a } \\
\text { partir de } \\
01 / 07 / 06 ; \text { IV } \\
\text { - 65\% a } \\
\text { partir de } \\
01 / 07 / 07\end{array}$ & $65 \%$ & & $\begin{array}{c}\text { I - 01/09/2003 } \\
\text { a 31/08/2004; } \\
\text { II - } \\
01 / 09 / 2004 \text { a } \\
31 / 07 / 2005 ; \\
\text { III - } \\
01 / 08 / 2005 \text { a } \\
30 / 06 / 2006 ; \\
\text { IV - } 1^{\circ} \text { dia } \\
\text { julho a } 30 \text { de } \\
\text { junho de cada } \\
\text { ano, a partir } \\
\text { de } 2007 \\
\end{array}$ & \\
\hline $\begin{array}{c}4.348 \mathrm{de} \\
30 / 6 / 2014\end{array}$ & $\mathrm{Jul} / 14$ & $\begin{array}{r}\text { I - } 67 \% \\
3 \\
\text { II - } 66 \% \\
3 \\
\text { D }\end{array}$ & $\begin{array}{l}2014 \mathrm{a} \\
2015 \mathrm{a} \\
\%\end{array}$ & $\begin{array}{c}\text { Média } \\
\text { aritmética do } \\
\text { Valor Sujeito } \\
\text { a } \\
\text { Recolhimento } \\
\text { (VSR) } \\
\text { relativo aos } \\
\text { depósitos da } \\
\text { poupança } \\
\text { rural } \\
\end{array}$ & $\begin{array}{c}\text { Inicia no } \\
\text { primeiro dia } \\
\text { útil do mês de } \\
\text { junho e } \\
\text { termina no } \\
\text { último dia útil } \\
\text { do mês de } \\
\text { maio do ano } \\
\text { seguinte }\end{array}$ & \\
\hline
\end{tabular}

(a) Banco da Amazônia S.A., Banco do Brasil S.A. e Banco do Nordeste do Brasil S.A.

Observação: mais detalhes podem ser encontrados no Manual de Crédito Rural (MCR)

Fonte: BACEN 
Tabela 9 - Direcionamento de depósito à vista - Crédito Rural

\begin{tabular}{|c|c|c|c|c|c|c|}
\hline Resolução & Aplicação & $\begin{array}{l}\text { Base de } \\
\text { Cálculo }\end{array}$ & $\begin{array}{c}\text { Período de } \\
\text { Cálculo }\end{array}$ & $\begin{array}{c}\text { Exigibilidade } \\
\left({ }^{a}\right)\end{array}$ & $\begin{array}{c}\text { Exigibilidade } \\
\text { CEF }\end{array}$ & $\begin{array}{c}\text { Deficiência no } \\
\text { Direcionamento }\end{array}$ \\
\hline $\begin{array}{c}2.881 \mathrm{de} \\
30 / 8 / 2001\end{array}$ & Set/01 & & $\begin{array}{l}\text { Efetivada no } \\
5^{\circ} \text { dia útil do }\end{array}$ & & & \multirow{8}{*}{$\begin{array}{l}\text { Fica a instituição } \\
\text { sujeita a } \\
\text { recolhimento:I - do } \\
\text { valor da deficiência } \\
\text { apurada, que ficará } \\
\text { retido até a data de } \\
\text { verificação } \\
\text { subsequente, sem } \\
\text { qualquer } \\
\text { remuneração; ouII - } \\
\text { de multa de } 40 \% \text {, } \\
\text { calculada sobre o } \\
\text { valor da deficiência } \\
\text { apurada }\end{array}$} \\
\hline $\begin{array}{c}3.208 \mathrm{de} \\
24 / 6 / 2004\end{array}$ & $\mathrm{Jul} / 04$ & $\begin{array}{l}\text { Saldo médio } \\
\text { diário das } \\
\text { rubricas } \\
\text { contábeis de } \\
\text { recursos à } \\
\text { vista sujeitos a } \\
\text { recolhimento } \\
\text { compulsório. }\end{array}$ & $\begin{array}{c}\text { mês de } \\
\text { setembro de } \\
\text { cada ano, com } \\
\text { base na média } \\
\text { diária da } \\
\text { exigibilidade } \\
\text { e das } \\
\text { aplicações do } \\
\text { período anual } \\
\text { de } 1^{\circ} \text { de } \\
\text { setembro a } 31 \\
\text { de agosto } \\
\text { imediatamente } \\
\text { anterior } \\
\end{array}$ & $25 \%$ & & \\
\hline $\begin{array}{c}3.556 \mathrm{de} \\
27 / 3 / 2008\end{array}$ & Mar/08 & \multirow{5}{*}{$\begin{array}{c}\text { Média } \\
\text { aritmética do } \\
\text { VSR apurado } \\
\text { no período de } \\
\text { cálculo }\end{array}$} & $\begin{array}{l}1^{\circ} \text { dia útil do } \\
\text { mês de junho } \\
\text { e término no } \\
\text { último dia útil } \\
\text { do mês de } \\
\text { maio do ano } \\
\text { seguinte }\end{array}$ & & - & \\
\hline $\begin{array}{c}3.623 \mathrm{de} \\
14 / 10 / 2008\end{array}$ & Nov/08 & & $\begin{array}{c}01 / 10 / 08 \mathrm{a} \\
31 / 05 / 09 \\
\end{array}$ & $\begin{array}{c}30 \% \text { de } 01 / 11 / 08 \\
\text { a 30/6/09 }\end{array}$ & & \\
\hline $\begin{array}{c}3.704 \mathrm{de} \\
26 / 3 / 2009 \\
\end{array}$ & $\mathrm{Jul} / 09$ & & $\begin{array}{l}\text { I - 01/10/08 a } \\
31 / 05 / 09 ; \text { II - }\end{array}$ & $\begin{array}{r}\mathrm{I}-30 \% \text { de } \\
01 / 07 / 09 \mathrm{a}\end{array}$ & & \\
\hline $\begin{array}{c}3.746 \mathrm{de} \\
30 / 6 / 2009\end{array}$ & $\mathrm{Jul} / 09$ & & $\begin{array}{c}\text { 01/06/09 a } \\
31 / 05 / 10 ; \text { III - } \\
01 / 06 / 10 \mathrm{a} \\
31 / 05 / 11 ; \mathrm{IV} \text { - } \\
01 / 06 / 11 \mathrm{a} \\
31 / 05 / 12 ; \mathrm{V}- \\
01 / 06 / 12 \mathrm{a} \\
31 / 05 / 13 ; \mathrm{VI}- \\
01 / 06 / 13 \mathrm{a} \\
31 / 05 / 14\end{array}$ & $\begin{array}{c}29 \% \text { de } 01 / 07 / 10 \\
\text { a } 30 / 06 / 11 ; \text { III - } \\
28 \% \text { de } 01 / 07 / 11 \\
\text { a } 30 / 06 / 12 ; \text { IV - } \\
27 \% \text { de } 01 / 07 / 12 \\
\text { a } 30 / 06 / 13 ; \mathrm{V}- \\
26 \% \text { de } 01 / 07 / 13 \\
\text { a } 30 / 06 / 14 ; \mathrm{VI}- \\
25 \% \text { de } 01 / 07 / 14 \\
\text { a } 30 / 06 / 15\end{array}$ & & \\
\hline $\begin{array}{c}4.096 \mathrm{de} \\
28 / 6 / 2012 \\
\end{array}$ & $\mathrm{Jul} / 12$ & & & & & \\
\hline $\begin{array}{c}4.348 \mathrm{de} \\
30 / 6 / 2014\end{array}$ & $\mathrm{Jul} / 14$ & $\begin{array}{c}\text { Média } \\
\text { aritmética dos } \\
\text { VSR, } \\
\text { deduzida de } \\
\text { R\$44 milhões. } \\
\text { A instituição } \\
\text { financeira que } \\
\text { apresentar } \\
\text { exigibilidade } \\
\text { igual ou } \\
\text { inferior a } \\
\mathrm{R} \$ 500.000,00, \\
\text { fica isenta do } \\
\text { cumprimento } \\
\text { da } \\
\text { exigibilidade }\end{array}$ & $\begin{array}{l}1^{\circ} \text { dia útil do } \\
\text { mês de junho } \\
\text { e término no } \\
\text { último dia útil } \\
\text { do mês de } \\
\text { maio do ano } \\
\text { seguinte }\end{array}$ & $34 \%$ & $\begin{array}{c}\text { I - } 6 \% \text { de } \\
01 / 07 / 12 \text { a } \\
30 / 06 / 13 \\
\text { II }-13 \% \text { de } \\
01 / 07 / 13 \text { a } \\
30 / 06 / 14 \\
\text { III }-20 \% \text { de } \\
01 / 07 / 14 \text { a } \\
30 / 06 / 15 \\
\text { IV }-27 \% \text { de } \\
01 / 07 / 15 \text { a } \\
30 / 06 / 16 \\
\text { V - 34\% a partir } \\
\text { de } 01 / 07 / 16\end{array}$ & \\
\hline
\end{tabular}

(a) Lista dos bancos participantes do crédito rural disponível em Banco Central do Brasil (2012).

Observação: mais detalhes podem ser encontrados no Manual de Crédito Rural (MCR)

Fonte: BACEN 
Tabela 10 - Direcionamento de depósito à vista - Microcrédito

\begin{tabular}{|c|c|c|c|c|c|}
\hline Resolução & Aplicação & $\begin{array}{l}\text { Base de } \\
\text { Cálculo }\end{array}$ & $\begin{array}{l}\text { Período de } \\
\text { Cálculo }\end{array}$ & $\begin{array}{c}\text { Exigibilidade } \\
\text { (a) }^{\text {a }}\end{array}$ & $\begin{array}{c}\text { Deficiência no } \\
\text { Direcionamento }\end{array}$ \\
\hline $\begin{array}{c}3.109 \mathrm{de} \\
24 / 7 / 2003\end{array}$ & Ago/03 & \multirow{8}{*}{$\begin{array}{c}\text { Média dos } \\
\text { saldos dos } \\
\text { depósitos à } \\
\text { vista } \\
\text { captados } \\
\text { pela } \\
\text { instituição } \\
\left(^{(a)}\right.\end{array}$} & \multirow{8}{*}{$\begin{array}{c}\text { Entre } 1^{\circ} \text { de julho de } \\
\text { um ano e } 30 \text { de junho } \\
\text { do ano seguinte }\end{array}$} & \multirow{3}{*}{$\begin{array}{c}2 \% \text {, observado que } \\
\text { nos meses de agosto } \\
\text { e setembro de } 2003 \\
\text { o percentual } \\
\text { mínimo é de } 1 \%\end{array}$} & \multirow[b]{2}{*}{-} \\
\hline $\begin{array}{c}3.212 \mathrm{de} \\
30 / 6 / 2004 \\
\end{array}$ & Jun/04 & & & & \\
\hline $\begin{array}{c}3.220 \mathrm{de} \\
29 / 7 / 2004\end{array}$ & Set/11 & & & & \multirow{6}{*}{$\begin{array}{c}\text { Deverá ser recolhida ao } \\
\text { Banco Central do Brasil, na } \\
\text { forma a ser estabelecida po } \\
\text { aquela Autarquia, } \\
\text { permanecendo indisponíve } \\
\text { até a data de verificação do } \\
\text { cumprimento da } \\
\text { exigibilidade no mês } \\
\text { seguinte }\end{array}$} \\
\hline $\begin{array}{c}3.310 \mathrm{de} \\
31 / 8 / 2005\end{array}$ & $\mathrm{Ago} / 05$ & & & & \\
\hline $\begin{array}{c}3.422 \mathrm{de} \\
30 / 11 / 2006\end{array}$ & Nov/06 & & & & \\
\hline $\begin{array}{c}4.000 \mathrm{de} \\
25 / 8 / 2011\end{array}$ & Ago/11 & & & & \\
\hline $\begin{array}{c}4.153 \mathrm{de} \\
30 / 10 / 2012 \\
\end{array}$ & Out/12 & & & & \\
\hline $\begin{array}{l}4.242 \mathrm{de} \\
1 / 7 / 2013\end{array}$ & Ago/13 & & & $2 \%$ & \\
\hline
\end{tabular}

(a) Não são considerados no cálculo da exigibilidade:

a.I - os depósitos à vista captados por instituições financeiras públicas federais e estaduais dos respectivos governos e de autarquias e de sociedades de economia mista de cujos capitais participem majoritariamente os respectivos governos

a.II - os depósitos à vista captados pelas instituições financeiras públicas estaduais titulados por entidades públicas municipais da respectiva unidade federativa.

(b) bancos múltiplos com carteira comercial, os bancos comerciais e a Caixa Econômica Federal

Fonte: BACEN 
Tabela 11 - Direcionamento de depósito de poupança

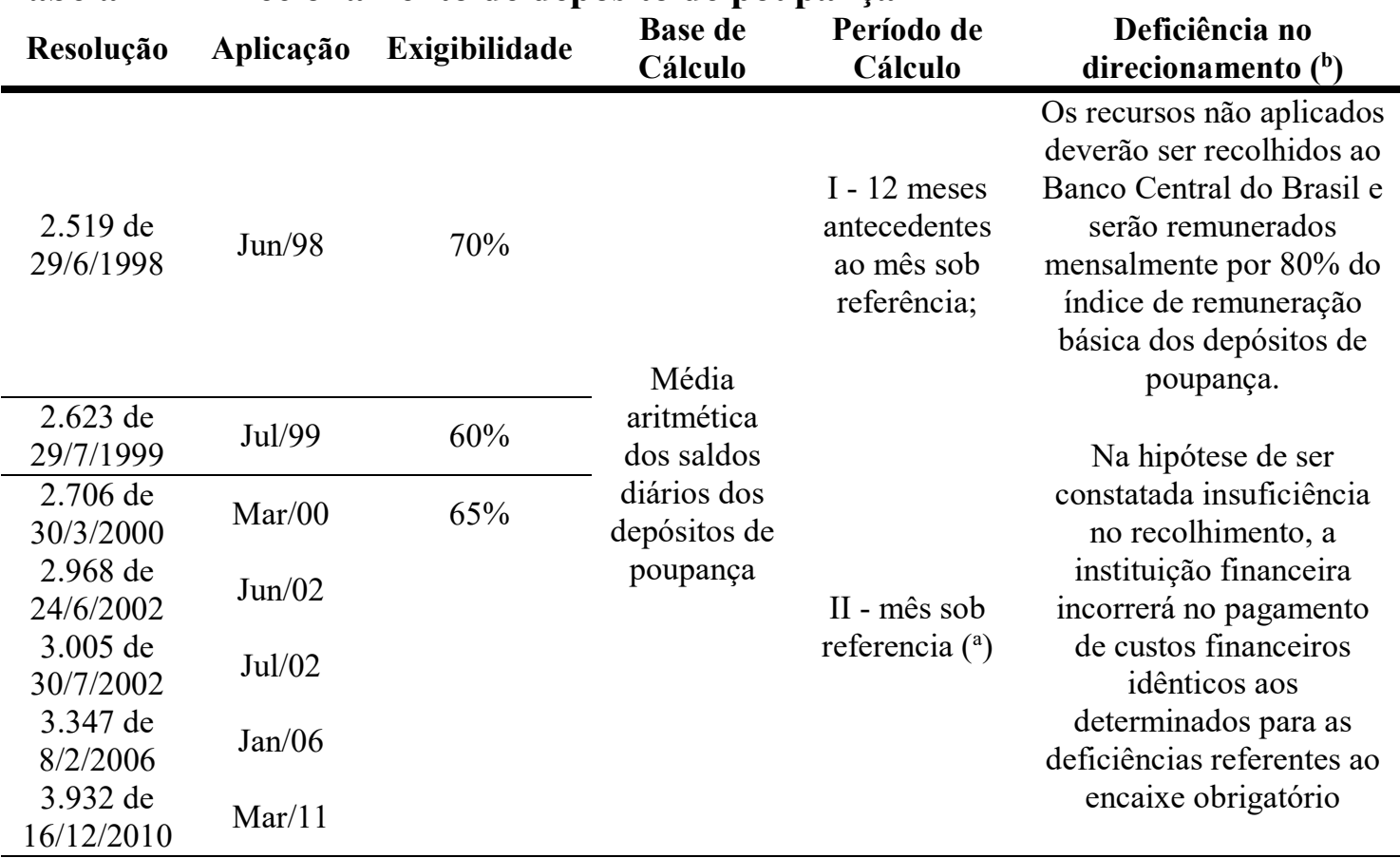

$\left({ }^{a}\right)$ O menor dos dois valores (BACEN,2014b)

(b) Quando a instituição financeira não cumpre o percentual mínimo de exigibilidade

Observação: não são todas as resoluções que alteram um dos itens da tabela, porém dispõe sobre direcionamento dos recursos captados em depósitos de poupança. Foram expostas apenas para informação de consulta

Integrantes do SBPE: ApePoupex, Bancoob, Bco Banestes S.A., Bco Bradesco S.A., Bco Citibank S.A., Bco Cooperativo Sicredi S.A., Bco Da Amazônia S.A., Bco Do Brasil S.A., Bco Do Est. De Se S.A., Bco Do Est. Do Pa S.A., Bco Do Estado Do Rs S.A., Bco Do Nordeste Do Brasil S.A., Bco Industrial E Comercial S.A, Bco Mercantil Do Brasil S.A., Bco Safra S.A., Bco Santander (Brasil) S.A., Brb - Bco De Brasília S.A., Caixa Econômica Federal, Hsbc Bank Brasil Sa BcoMultip, Itaú Unibanco Bm S.A.

Fonte: BACEN 